تأثير بعض تقنيات التطريز الآلى على

المظهرية والخواص الميكانيكية لأقمشة

\title{
الملابس الخفيفة
}

أ.م.د/ أسماء سامى عبد العاطى سويلم

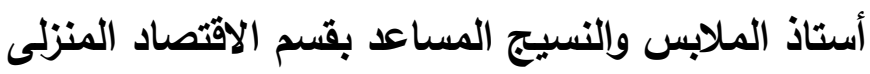

كلية التربية النوعية - جامعة طنطا

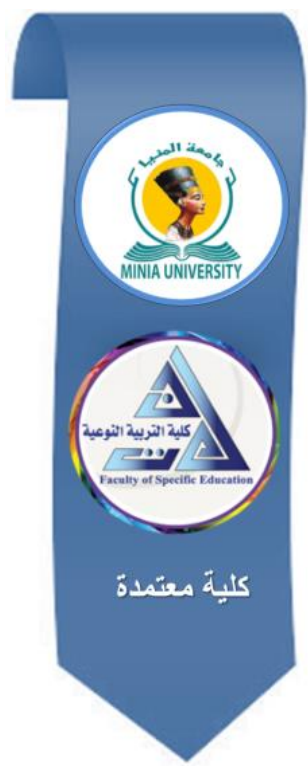

مجلة البحوث في مجالات التربية التوعية

معرف البحث الرقمي DOI: 10.21608/jedu.2021.93633.1451:

المجلد الثامن العدد 39 ـ مارس 2022

الترقيم الدولي

\section{P-ISSN: 1687-3424 E- ISSN: 2735-3346}

https://jedu.journals.ekb.eg/ موقع المجلة عبر بنك المعرفة المصري

http://jrfse.minia.edu.eg/Hom

موقع المجلة

العنوان: كلية التربية النوعية ـ جامعة المنيا ـ جمهورية مصر العربية

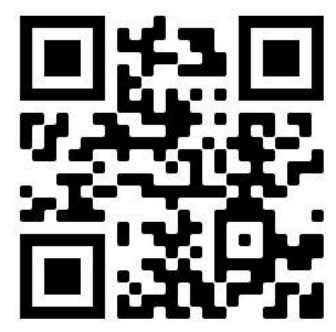


مجلة البحوث فى مجالات التربية النوعية 
تأثير بصض تقتيات التطريز الآلى على المظهرية والخواص الميكانيكية لأقمشة

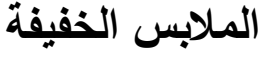

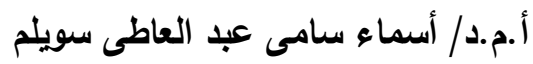

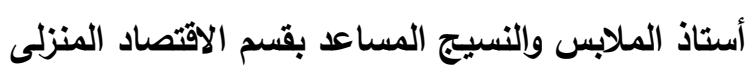

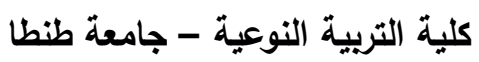

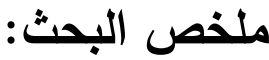

يهذف هذا البحث إلى دراسة تأثير بعض تقنيات التطريز الآلى على المظهرية والذواص الميكانيكية لأقشة الملابس الخفيفة للتوصل إلى أنسب ( نوع غرزة تطريز آلى، نوع للوحدة الزخرفية، حجم للوحدة الزخرفية، عدد للوحدات الزخرفية المستخدمة

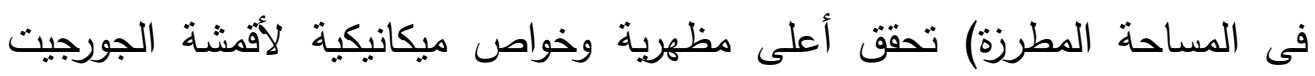

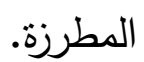

*وتبرز أهية البحث فى المساهمة فى رفع كفاءة ملابس السيدات المصنعة من

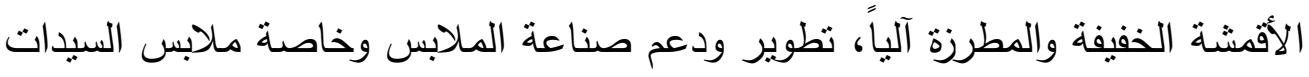
الخارجية من خلال الاستفادة من إمكانيات ماكينات التطريز الآلى فى تحسين القيمة الوظيفية والجمالية للملابس. "ولتحقيق أهداف البحث نم تطريز (54) عينة من قماش الجورجيت آلياً بمتغيرات البحث المختلفة، وتم إعداد استبيان للمتخصصين، وكذلك استبيان للمستهكات وذللك

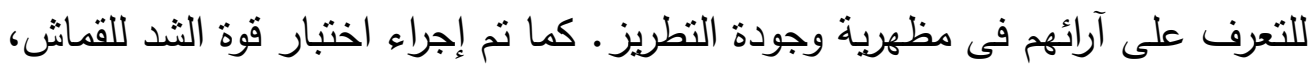

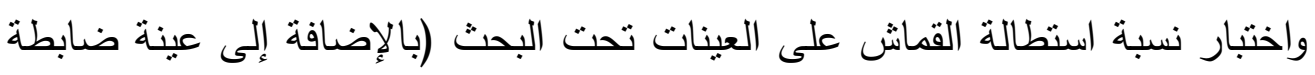

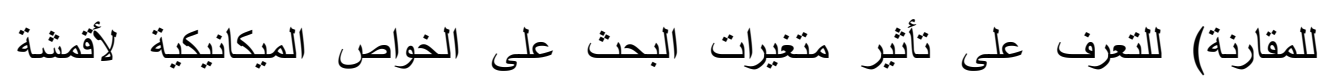
الجورجيت الخفيفة، وتم إجراء الاختبارت بشركة مصر للغزل والنسيج باتيرت بالمحلة الكبرى. "وتوصل البحث للنتائج التالية: * * بالنسبة لمظهرية وجودة تطريز العينات تحت البحث: 1- أفضل نوع لغرزة النطريز الآلي كانت Satin stitch وفقاً لآراء الدتخصصين الفين،

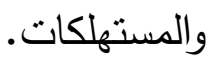


2- أفضل نوع للوحدة الزخرفية كانت (هندسية) وفقاً لآراء المتخصصين، بينما

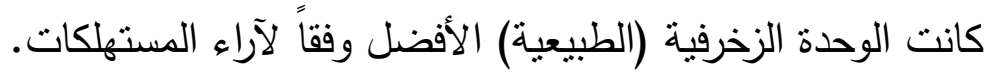

3- عدم وجود فرق دال إحصائياً بين حجم الوحدة الزخرفية وفقاً لآراء

المتخصصين ويتفق ذلك مع نتائج الخواص الميكانيكية للعينات المطرزة

تحت البحث، بينما أفضل حجم للوحدة الزخرفية كان (3×3سم) وفقاً لآراء

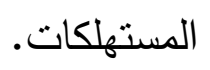

4- أفضل عدد للوحدات الزخرفية فى المساحة المطرزة كان 3 وحدات وفقاً لآراء

المتخصصين، بينما كان عدد 5 وحدات الأفضل وفقاً لآراء المستهلكات.

5-وجود توافق بين التقييم من الناحية العلمية والعملية حيث أن العلاقة الارتباطية

بين ترتيب المتخصصين والمستهلكات للعينات تحت البحث كانت علاقة

$$
\text { طردية ودالة احصائياً. }
$$

** بالنسبة للخواص الميكانيكية(قوة الشد، نسبة الاستطالة) للعينات تحث البحث: * أفضل العينات كانت رقم (22) بمساحة منالية (200) ومعامل الجودة

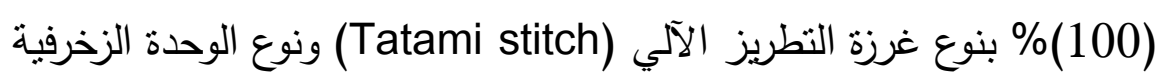

$$
\begin{aligned}
& \text { (هندسية) وحجم الوحدة الزخرفية (4×4 سم) وعدد الوحدات الزخرفية في } \\
& \text { المساحة المطرزة (3 وحدات). }
\end{aligned}
$$

*وأوصى البحث بالاستفادة من نكنولوجيا ماكينات التطريز الآلى المتطورة وتوظيفها فى مجال الملابس، وعمل مزيد من الأبحاث التجريبية على أنواع أخرى من الأقمشة الخفيفة باستخدام تقنيات إضافية تخدم مجال التطريز الآلى.

الكلمات المفتاحية:

تقنيات، التطريز الآلى، المظهرية، أقمشة الملابس الخفيفة 


\title{
The Effect of Some Automated Embroidery Techniques on the Appearance and Mechanical Properties of Light Clothing Fabrics
}

\author{
Dr.Assmaa Samy Abd-Elaty Swelam \\ Assistant professor of Clothes and Textile, \\ Department of Home Economics, \\ Faculty of Specific Education, \\ Tanta University
}

\section{Abstract:}

This research aims to study the effect of some automated embroidery techniques on the appearance and mechanical properties of light clothing fabrics to reach the most appropriate (automated embroidery stitch type, type of decorative unit, size of decorative unit, number of decorative units used in the embroidered area) to achieve the highest appearance and mechanical properties of embroidered Georgette fabrics.

*The importance of the research is in contributing to raising the efficiency of women's clothing manufactured from light fabrics and automated embroidered, developing and supporting the clothing industry, especially women's outerwear by taking advantage of the capabilities of automated embroidery machines to improve the functional and aesthetic value of clothing.

* To achieve the objectives of the research, (54) samples of Georgette fabric were automated embroidered with different research variables, and a questionnaire was prepared for specialists, as well as a questionnaire for consumers in order to identify their opinions on the appearance and quality of embroidery. The Tensile Strength test of the fabric, and the fabric Elongation Ratio test were conducted on the samples under research (in addition to a control sample for comparison) to identify the effect of the research variables on the mechanical properties of light Georgette fabrics. The tests were conducted at Misr Spinning and Weaving Company in El- Mahalla El- Kubra.

* The research reached the following results:

** Regarding the appearance and quality of the embroidery of the samples under research: 
1- The best type of automated embroidery stitch was Satin stitch according to the opinions of specialists and consumers.

2- The best type of decorative unit was (geometric) according to the opinions of specialists, while the decorative unit (natural) was the best according to the opinions of consumers.

3- There is no statistically significant difference between the size of the decorative unit according to the opinions of specialists and this agrees with the results of the mechanical properties of the embroidered samples under research, while the best size of the decorative unit was $(3 \times 3 \mathrm{~cm})$ according to the opinions of consumers.

4- The best number of decorative units in the embroidered area was 3 units according to the opinions of specialists, while the number of 5 units was the best according to the opinions of consumers.

5- There is agreement between the evaluation from a scientific and practical point of view, as the correlation between the order of specialists and consumers of the samples under research was direct and statistically significant.

** For mechanical properties (Tensile Strength, Elongation Ratio) of the samples under research:

* The best sample is No. (22) with an ideal area (200) and quality factor $(100 \%)$ with the type of automated embroidery stitch (Tatami stitch) and the type of decorative unit (geometric), the size of the decorative unit $(4 \times 4 \mathrm{~cm})$ and the number of decorative units in the space embroidered (3 units).

* The research recommended taking advantage of the technology of advanced automated embroidery machines and employing them in the field of clothing, and conducting more experimental researches on other types of light fabrics using additional techniques that serve the field of Automated Embroidery.

\section{key words:}

Techniques, Automated Embroidery, The Appearance, Light Clothing Fabrics 


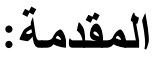

أصبح التطريز فى عصرنا الحالى عنصراً مهماً فى صناعة الملابس والمفروشات حيث

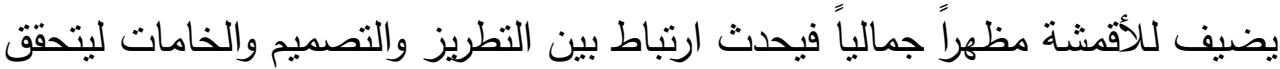
الغرض الوظيفى من المنتج (حلاوة وآخرون، 2018). ويعد فن التطريز عاملاًاً هاماً فى دعم اقتصاد كثير من الدول لتصدير بعض المنتجات المطرزة إلى الخارج (السلمان، 2020). وأدى التقدم التكنولوجى إلى تصنيع ماكينات التطريز الآلى لسرعة الحصول على المنتجات بأعلى معدلات الجودة والمنافسة العالمية من خلال إظهار جماليات التصميم الزخرفى ثم تتفيذه بدقة بالغة (حسن، 2002). وفى الفترة الأخيرة يعتبر النطريز الآلى صناعة قائمة بذاتها تواكب تطور صناعة الملابس فقد تطورت آلات النطريز وأساليب تشغيلها وقدراتها الإنتاجية كما أمكن تطويع إمكانات الحاسب الكابس الآلى للاستفادة منها فى مجال التطريز الآلى (سليمان، 2017). ونظراً لظهور

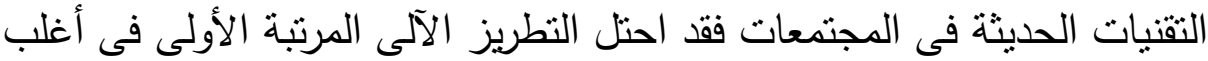

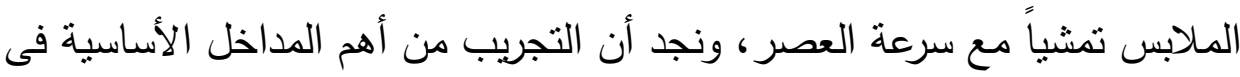
مجال التطريز، فهو يساعدعلى نمو التفكير الإبداعى والطلاقة التتكيلية (اليمانى و قاضى، 2011). وبالرغم من التطور الكبير فى صناعة التطريز الآلى إلا أن التطريز

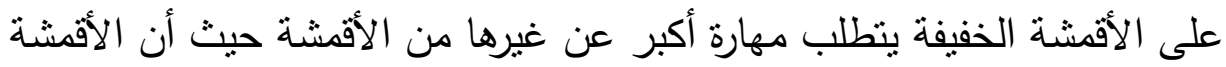

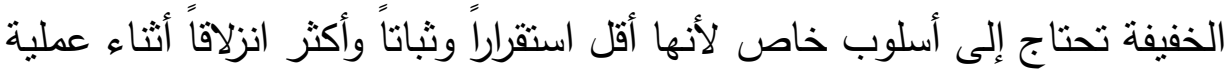

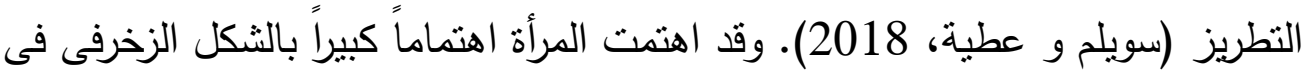
ملابسها والذى يتضح فى النطريز حيث يعطى تأثيرات وملامس منتوعة لسطح القماش

باستخدام الغرز الزخرفية والخيوط المختلفة (Snook, Barbara, 1972). ونجد العديد من الدراسات تناولت التطريز الآلى منها دراسة (إبراهيم، 2010) والتى التى استفادت من تكنولوجيا ماكينات التطريز الآلى فى عمل تصميمات جديدة لمكملات الملابس، وتوصلت الدراسة لإمكانية استخدام تكنولوجيا ماكينات التطريز الآلى كأحد الأساليب التقنية والفنية لتنفيذ المكملات المقترحة لما لها من تأثير وظيفى وجمالى. وهدفت دراسة (عبد وآخرون، 2014) للتعرف على غرز التطريز الآلى ومواصفاتها والعوامل المؤثرة عليها للوصول لأنسب ظروف لنطريز الأقششة المستخدمة واختيار 
الخامات الأفضل للتطريز الآلى والتى تظهر فيها الغرز متقنة. وقامت بدراسة حالة على إحدى الشركات بيلغاريا لتحديد (Radostina,et,al.,2016) العيوب المظهرية فى الأقشة المطرزة وتصنيفها، وتوصلت الدراسة لتصنيف العيوب إلى عيوب مرتبطة بالتصميم وعيوب مرتبطة بعملية النطريز وأن أكثر العيوب المؤثرة على مظهرية التطريز هى مشاكل مرحلة التصميم. وتناولت دراسة (سليمان، 2017) أثز اختلاف كثافات بعض غرز التطريز الآلى على مظهرية منتجات "الفولى فاشون" من خلال تحديد غرز التطريز الآلى المناسبة لمنتجات نريكو الفولى فاشون المتتاولة بالبحث (انترلوك، دربى، جرسيه) وقياس تأثير أنواع الغرز (Arrowhead Stitch- Wave- Tick) 105) على مظهرية الفولى فانون، وأثنتت الدراسة أن كثافة غرزة التطريز (45) كانت الأفضل للنالاث خامات وأن غرزة (Wave) كانت الأفضل لخامة الانترلوك بينما كانت غرزة النطريز الآلى (Tick) الأفضل لخامة الدربى وكانت غرزة (Arrowhead) الأفضل لخامة الجرسيه. واهتمت دراسة (حلاوة وآخرون، 2018) بالنسيج والتطريز فى التصميم وتأثثرهما على الأداء الوظيفى لأقمشة المفروشات حيث نم إنتاج أقمشة منسوجة بأسلوب اللحمة الزائدة وأسلوب النقشة العادية وأخرى ممانلة لها باستخدام تكنولوجيا التطريز بنفس التصميم واستخدام خيط التطريز ذاته كأحد اللحمات المستخدمة فى إنتاج الأقمشة المنفذة بأسلوب النسيج وتم إجراء اختبار الاحتكالك ومقارنة الأقمشة ببعضها للوصول لأفضل نوع من الأفشة، وأظهرت نتائج الاختبار أن العينات المنسوجة بأسلوب اللحمة الزائدة حصلت على أعلى مقاومة للاحتكالك. وأوضحت دراسة (السيد و حمودة، 2018) تأثير بعض الأساليب التطبيقية (طريقة التطريز (على القماش مباشرة، على قماش جوخ)، عدد طبقات الحشو (طبقة واحدة، طبقتين)، نوع خيط التطريز ، كثافة غرزة التطريز) على الخواص الوظيفية (وزن المتر المربع، السمك، الصلابة، مظهرية التطريز) لأقمشة تريكو اللحمة المخلوطة بالليكرا

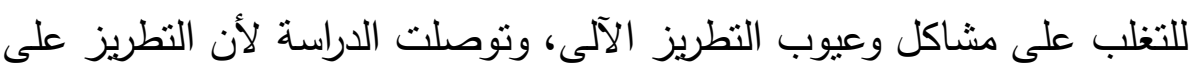
القماش مباشرة، وبطبقة حشو واحدة، وبخيط حرير صناعى، وكثافة غرزة (4000) غ/ دقيقة كانت الأفضل. ويينت دراسة (حربى و سليمان، 2018) أثز بعض أساليب 
التضريب المطرز آلياً على مظهرية الجلود الصناعية، وتوصلت الدراسة لأن التضريب الثبكى أعطى أفضل النتائج بالنسبة للتناث خامات المستخدمة بالدراسة وأن استخدام الحشو الاسفنج عند تطريز التضريب كان الأفضل وأن استخدام التقوية غير اللاصقة بالفية أعطى نتائج أفضل لمظهرية تطريز التضريب وذلك بالنسبة للنالاث خامات المستخدمة بالدراسة. ودمجت دراسة (أبو خزيم، 2019) أسلوب الجاكارد مع التطريز الآلى بطى بلى

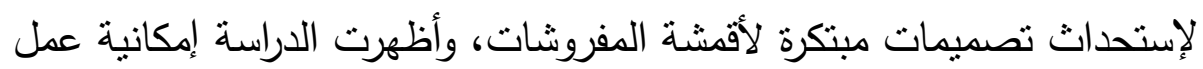

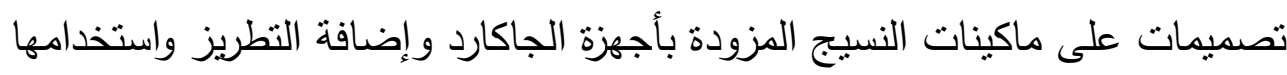
على أقمشة المفروشات كما أن التطريز يعطى مزيداً من الرونق والحيوية لأقمشة المفروشات. واستخدمت دراسة (غازى و الزهرانى، 2019) الخيوط المضيئة كأحد الخامات المستحدثة فى إثراء الثكل الجمالى فى تصميم مكملات الملابس باستخدام تقتيات التطريز الآلى، وتوصلت الدراسة لنجاح استخدام الخيوط المضيئة على ماكينة التطريز الآلى وذللك بدمجها مع الخيوط الحريرية فى عمل الوحدات الزخرفية واستخدامها فى الحلى بشكل يتماشى مع اتجاهات الموضة المعاصرة. وأشارت دراسة (سويلم، 2021) لتأثير متغيرات التطريز الآلى (نوع الغرز - كثافة الغرز - نوع الخيططرق التقوية) على مظهرية الأقشة العازلة للماء، وتوصلت الدراسة لأن أفضل غرز

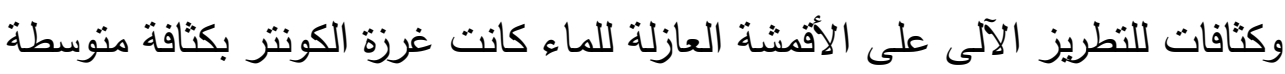

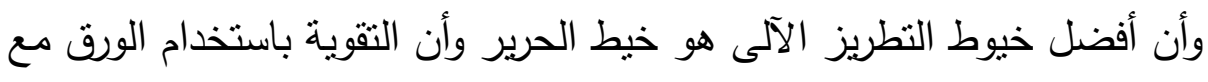
الحشو غير اللاصق كانت الأفضل. واستفادت دراسة (محمد، 2021) من النياشين

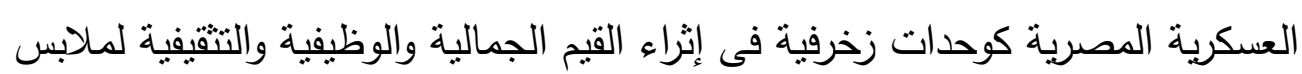
الأولاد فى مرحلة الطفولة المتأخرة باستخدام التطريز الآلى لتنفيذها، وجاءت آراء المتخصصين والمستهلكين إيجابية مما يدل على نجاح الفكرة. وهناك دراسات أخرى تناولت التطريز الآلى لملابس السيدات منها دراسة (جعفر و الزهرانى، 2011) التى وظفت زخارف الطراز الأندلسى فى إثراء الملابس النسائية بالتطريز الآلى، وتمكنت الدراسة من ابتكار مجموعة من الأزياء المعاصرة باستخدام وحدات زخرفية إسلامية محورة تمت معالجتها بعدة برامج للرسم والتصميم والتطريز الآلى. وطوعت دراسة (زيدان و عوام، 2020) خصائص الخيوط المضيئة فى إثراء 
العباءة النسائية باستخدام تقنيات التطريز الآلى، وتوصلت الدراسة لأن التطريز الأكثر

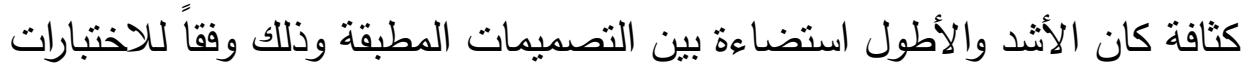
المعملية وأن التصميم الأكثر تفضيلاً بالنسبة للمتخصصين ليس بالضرورة الأفضل

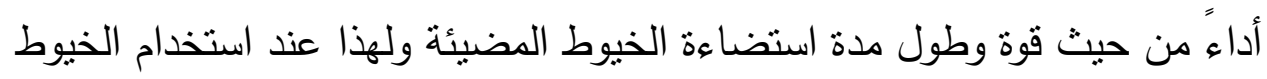

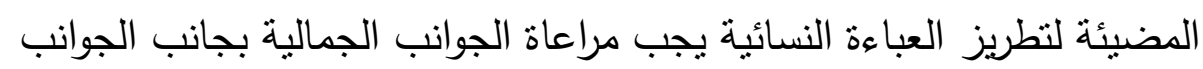
الوظيفية للخيوط المضيئة. كما أن هناك دراسات تتاولت التطريز الآلى على الأقمشة الخفيفة منها دراسة (أبو

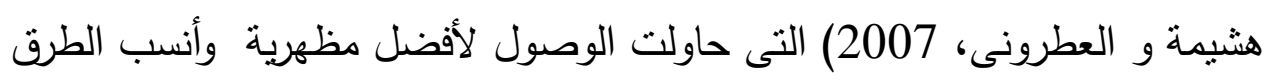

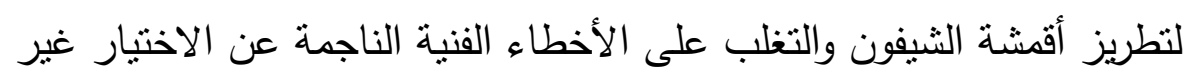
المناسب (لنوع وسمك خامة التقوية- كثافة غرز التطريز - مقاس الإبرة). وتعرفت التهن

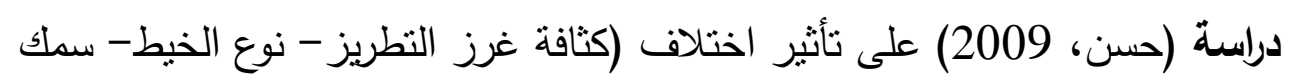

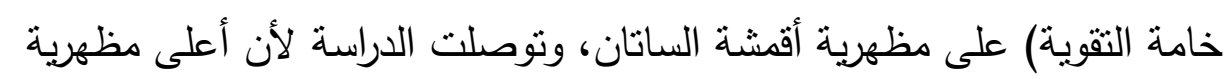
لقماش الساتان الخفيف كانت للعينة ذات الكثافة المنخفضة وخيط البولى استر مع ونى التقوية متوسطة السمك وبالنسبة للستان منوسط الوزن كانت الأفضلية للكثافة المرتقعة وخيط البولى استر واستخدام التقوية المتوسطة. وطبقت دراسة (عبد الفتاح و هاشم،

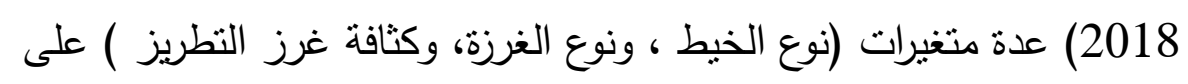
قماش التل للتعرف على قابليته للتطريز الآلى وكذلك الوصول إلى أنسب متغيرات الدراسة فى تحقيق جودة ومظهرية أقمشة ستائر التل. وأكدات دراسة (سويلم و عطية،

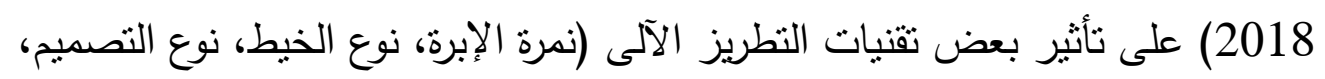

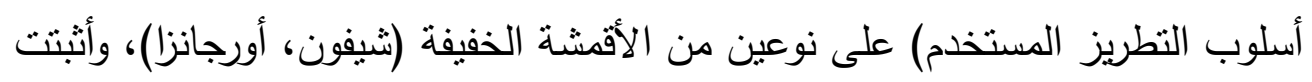

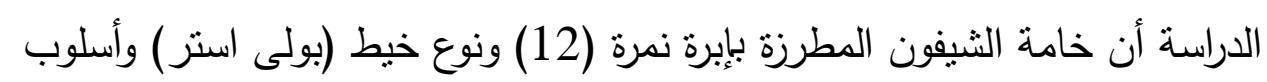
تطريز (حشو) ونوع تصميم (متصل) كانت الأفضل من حيث الخواص الميكانيكية (قوة شد القماش، نسبة استطالة القماش). وقدمت دراسة (سلامة، وندة 2019) القيم

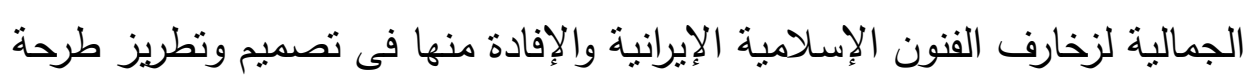
الزفاف، وتمكنت الدراسة من استخراج عدد كبير من الوحدات الزخرفية مما أظهر الإنة

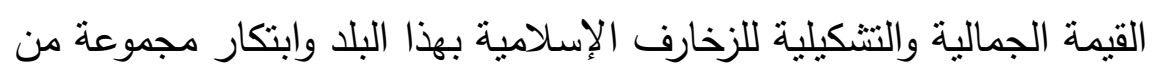


التصميمات لطرحة الزفاف العصرية ونفذت أفضل ثناث تصميمات بخامة التل ونت تطريزها بخيوط حرير وخيوط سيرما على ماكينة التطريز الآلى.

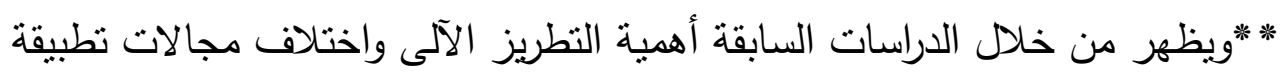
وتتوعها وهذا ما يؤكد عليه البحث الحالى، وحيث أن جودة الملابس المطرزة تعتمد

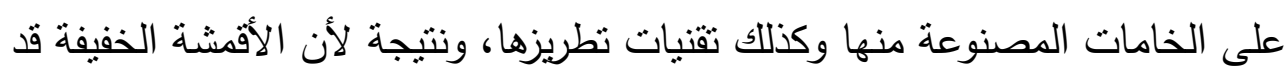

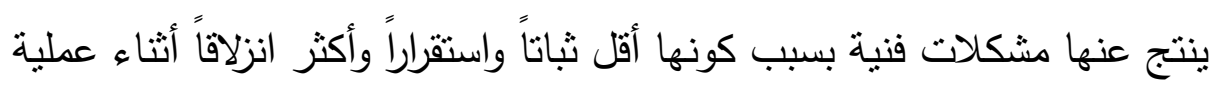

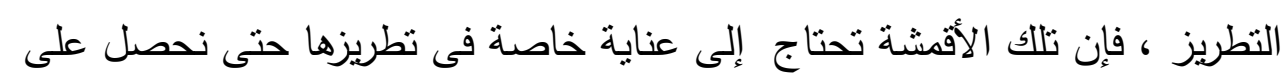

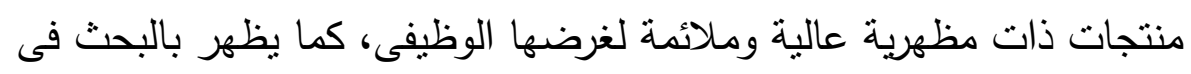
الدراسات السابقة ندرة الدراسات التى طبقت التطريز الآلى على ملابس السيدات

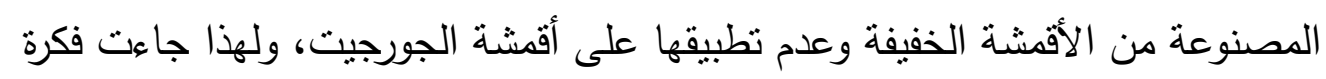
البحث بعنوان "تأثير بعض تقنيات النطريز الآلى على المظهرية والخواص الميكانيكية

لأقمشة الملابس الخفيفة". مشكلة البحث:

من خلال ما تقدم يمكن تحديد مشكلة البحث فى التساؤل الرئيسى التالى: ما تأثير بعض نقنيات التطريز الآلى على المظهرية والخواص الميكانيكية لأقمشة

الملابس الخفيفة؟ - ماليز

ويتفرع من هذا التساؤل الأسئلة الفرعية التالية:

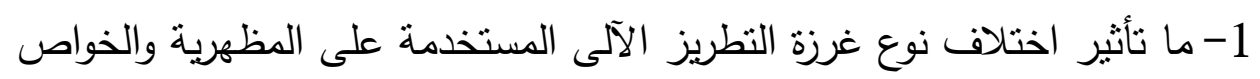

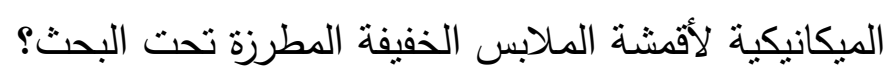

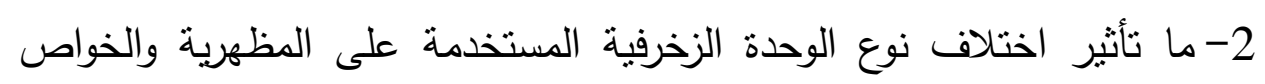

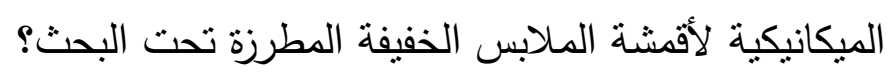
3- ما تأثير اختلاف حجم الوحدة الزخرفية المستخدمة على المظهرية والخواص لأنس الميكانيكية لأقششة الملابس الخفيفة المطرزة تحت البحث؟ 4- ما تأثير اختلاف عدد الوحدات الزخرفية المستخدمة فى المساحة المطرزة على لأى

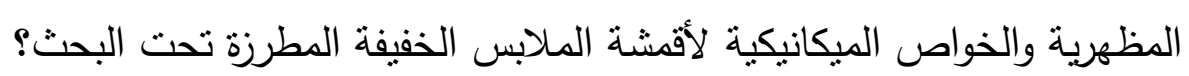


5- ما العلاقة بين تقييم المتخصصين و المستهلكات لمظهرية وجودة الأقششة

$$
\text { أهداف البحث: المطرزة تحت البحث؟ }
$$

1-محاولة التغلب على المشاكل الفنية التى تواجه تطريز الأقمشة الخفيفة المستخدمة فى صناعة ملابس السيدات الخارجية والناتجة عن الاختيار غير المناسب لبعض عوامل التطريز الآلى، وذلك باستخدام البحث العلمى. 2- التعرف على أنسب نوع غرزة تطريز آلى مستخدمة تحقق أعلى مظهرية وخواص ميكانيكية لأقشة الملابس الخفيفة المطرزة تحت البحث. 3- التوصل إلى أنسب نوع للوحدة الزخرفية المستخدمة يحقق أعلى مظهرية وخواص ميكانيكية لأقشة الملابس الخفيفة المطرزة تحت البحث. 4- تحديد أنسب حجم للوحدة الزخرفية المستخدمة يحقق أعلى مظهرية وخواص ميكانيكية لأقشتة الملابس الخفيفة المطرزة تحت البحث. 5- التوصل إلى أنسب عدد للوحدات الزخرفية المستخدمة فى المساحة المطرزة

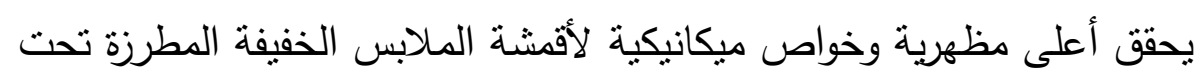
البحث. 6- التعرف على العلاقة بين تقييم المتخصصين والمستهلكات لمظهرية وجودة الأقمشة المطرزة تحت البحث. أهمية البحث:

1- المساهمة فى رفع كفاءة ملابس السيدات المصنعة من الأقمشة الخفيفة

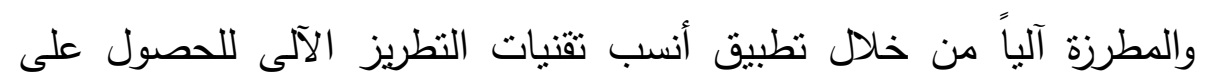
منتجات ذات جودة وكفاءة عالية تمكنها من المنافسة محلياً وعالمياً. 2- نطوير ودعم صناعة الملابس وخاصة ملابس السيدات الخارجية من خلا وله الاستفادة من إمكانيات ماكينات التطريز الآلى فى تحسين القيمة الجمالية والوظيفية للملابس. 
3- إثراء المقررات المرتبطة بالتطريز وبخاصة التطريز الآلى فى الكليات

المتخصصة.

\section{فروض البحث:}

1-نوجد فروق ذات دلالة إحصائية بين نوع غرزة التطريز الآلي لعينات أقششة الملابس الخفيفة وفقاً لآراء المتخصصين. 2-نوجد فروق ذات دلالة إحصائية بين نوع الوحدة الزخرفية لعينات أقمشة الملابس الخفيفة وفقاً لآراء المتخصصين. 3-توجد فروق ذات دلالة إحصائية بين حجم الوحدة الزخرفية لعينات أقمشة الملابس الخفيفة وفقا لآراء المتخصصين. 4- توجد فروق ذات دلالة إحصائية بين عدد الوحدات الزخرفية لعينات أقمشة الملابس الخفيفة وفقا لآراء المتخصصين. 5- توجد فروق ذات دلالة إحصائية بين محاور التقيم (ككل) لعينات أقمشة الملابس الخفيفة وفقاً لآراء المتخصصين. 6- توجد فروق ذات دلالة إحصائية بين بنود التقييم لعينات أقششة الملابس

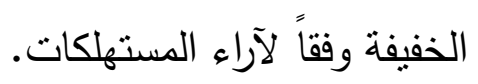

7-توجد علاقة ارتباطية بين ترتيب المتخصصين وترتيب المستهلكات لعينات

أقششة الملابس الخفيفة المطرزة.

8- يوجد فرق دال إحصائياً عند مستوي (0.05) بين نوع غرزة التطريز الآلى ، Satin (Straight stitch ، Tatami stitch ، Satin stitch) الميكانيكية لأقمشة الملابس الخفيفة: قوة الثد(كجم)، نسبة الاستطالة (\%). 9-يوجد فرق دال إحصائياً عند مستوي (05) بين نوع الوحدة الزخرفية

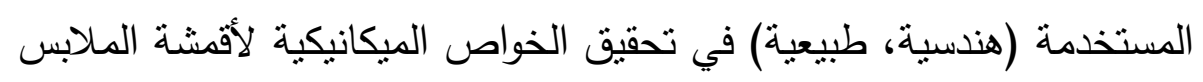
الخفيفة: قوة الثد (كجم)، نسبة الاستطالة (\%).

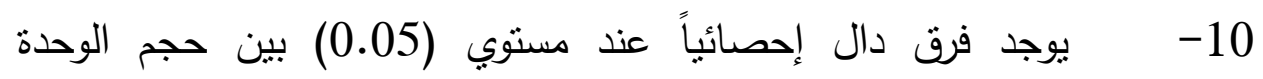
الزخرفية المستخدمة (5×5 سم ، 4×4 سم، 3×3 سم) في تحقيق الخواص

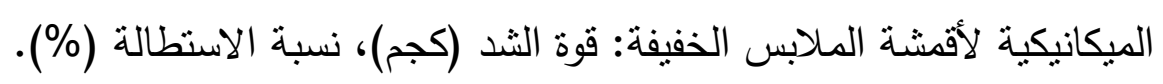


11- - 10.05) بين فرق عدد الوحدات الزخرفية (3 وحدات ، 5 وحدات ، 7 وحدات) في تحقيق الخواص الميكانيكية

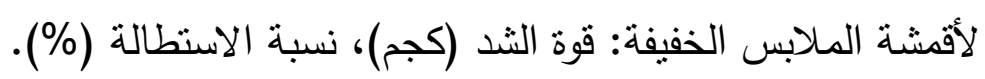

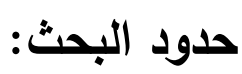

\section{1- حدود تطبيقية:}

- أقشة الجورجيت الخفيفة المستخدمة فى صناعة ملابس السيدات

$$
\text { الخارجية (الفساتين). }
$$

- ثلاث أنواع مختلفة من غرز التطريز الآلى: (Statami ، Satin stitch .(Straight stitch ، stitch - نوعان للوحدة الزخرفية المستخدمة: (هندسى، طبيعى (نباتى)).

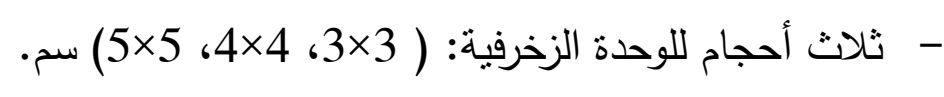
- ثلاث أعداد للوحدات الزخرفية: (3 ، 5 ، 7 7) وحدات. - المساحة المطرزة: (55×35) سم. - الخواص الميكانيكية المقاسة لأقشة الجورجيت المستخدمة المثة تحت البحث: قوة شد القماش، نسبة الاستطالة للقماش. 2- حدود بشرية: الفتيات والسيدات من عمر (20-35). 3- حدود زمانية: تم إجراء البحث فى الفترة الزمانية من 4/ 2021 م وحتى 8 / - 2021

4-حدود مكانية: ورشة للتطريز الآلى بمدينة طنطا فى محافظة الغربية، وتم استطلاع آراء المستهلكات بنفس المدينة والمحافظة، كما تم إجراء الاختبارات المعملية بشركة مصر للغزل والنسيج بالمحلة الكبرى. منهج البحث: يتبع البحث الحالى المنهج الوصفى والمنهج التجريبى والمنهج التحليلى لتحقيق أهداف البحث والتحقق من فروضه. 
وتتنمل على (55) عينة مقسمة كالتالى:

- (54) عينة من قماش الجورجيت المطرزة آلياً باستخدام متغيرات البحث المختلفة (ثلاث غرز للنطريز الآلى ، ونوعان للوحدة الزخرفية ، وثناث أحجام للوحدة الزخرفية، وثلاث أعداد للوحدات الزخرفية).

-عينة ضابطة واحدة بدون تطريز لقماش الجورجيت وذلك للمقارنة بينها وبين العينات المطرزة من حيث الخواص الميكانيكية المقاسة . أدوات البحث:

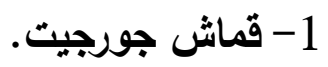

2- خيط التطريز المستخدم: خيط حريز، حيث توصلت دراسة (عبد الفتاح و هاثم، 2018)، ودراسة (سويلم، 2021) لأفضلية خيط الحربر مقارنة بخيط البولى استز والخيوط المعدنية فى تأثثره على مظهرية العينات المنفذة، وأكدته دراسة (سلامة، 2019) التى أشارت بأن الخيوط التى تمثاز بنعومة ومتانة فائقة هى الاختيار الأفضل كالخيوط الحريرية، لذلك تم اختيار هذا النوع من الخيوط لتنفيذ العينات تحت البحث. 3-نمرة الإبرة المستخدمة: 14 (نظام أمريكى)، حيت أثتتت دراسة (سويلم و عطية، 2018) وجود فروق ذات دلالة إحصائية بين العينات المنفذة لصالح إبرة 14 وفقاً لآراء المحكمين. 4- فازلين مائى، حيث أكدت دراسة (حسن، 2009) أن الخامات القابلة للذوبان فى الماء تتحلل تاركة غرز التطريز على سطح الخامة المطرزة وأنها تعد الأنسب للأقمشة الرقيقة والتى قد تتأثز سلبياً بالأنواع الأخرى من خامات التقوية، وكذلك ذكرت دراسة (الطوبشى، 2000) بضرورة استخدام الأقمشة غير المنسوجة أو ورق أسفل القماش للحفاظ على مظهرية التطريز . 5- ماكينة AKRON صينية المنشأ متعددة الرؤوس (12 رأس) للتطريز الآلى وعيل

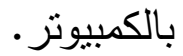


6- استمارة تقييم عينات الأقمشة المطرزة آلياً خاصة بالمتخصصين (ملحق 2)، حيث كان عدد المتخصصين (10) من السادة أعضاء هيئة التدريس تخصص الملابس والنسيج بالجامعات المصرية المختلفة (ملحق 3). 7- استمارة تقييم عينات الأقمشة المطرزة آلياً خاصة بالمستهلكات (ملحق 4 )، حيث كان عدد المستهلكات (20) من أفراد المجتمع من الفتيات والسيدات من بن

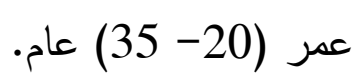

8- جهاز Testing Instrument, Hans Haer AG-CH, Zurich يعمل بطريقة المعدل الثابت للسرعة لقياس قوة شد القماش ونسبة استطالة القماش حيث ثم قياسهما فى اتجاه السداء لكون الأقمشة خفيفة. 9- البرنامج الإحصائى المستخدم، حيث تم إجراء المعالجات الاحصائية باستخدام البرنامج الاحصائي Spss الاصدار الحادي والعشرون.

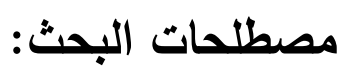
تقنيات:

مفردها تقنية: مصدر صناعى من تقن وهى أسلوب أو فنية فى إنجاز عمل أو بحث علمى ونحو ذلك، أو جملة الوسائل والأساليب والطرائق التى تختص ونس

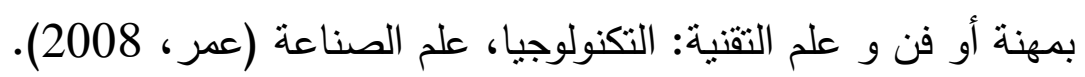
التطريز الآلى: هو زخرفة النسيج بعد عملية نسجه بواسطة الإبر الخاصة بالتطريز

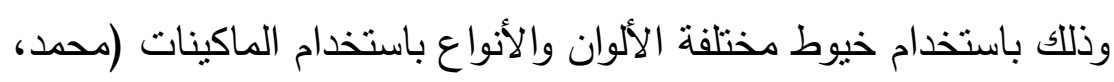

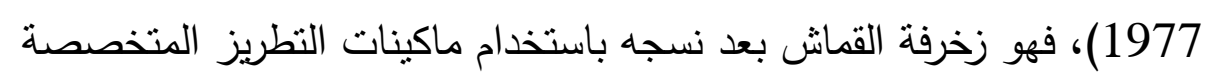

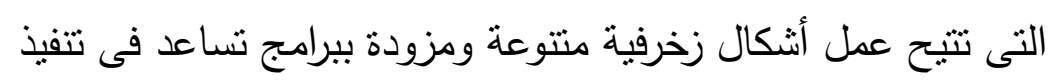
التصميمات المختلفة بمقاسات مختلفة وفقاً لرغبة المصمح (غازى و الزهرانى، . 2019

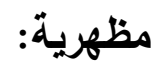

هى اسم مؤنث منسوب إلى مظهر (مظهرية WwW.almaany.com)، وتعرف بأنها الحكم على الثىء كما يجب أن يكون أو على ماهية شكل ملثل 
.(www.dictionary. Cambridge.org appearance)

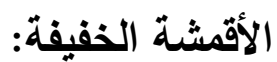

هى الأقشة الرقيقة الثفافة ومن هذه الأقشة: أقشة التل، أقمشة الأورجانزا، أقشة الجورجيت، أقشة الثشفون (أبو موسى، 2001).

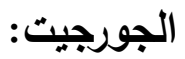

هو نسيج شفاف خفيف الوزن لا يسطَعُ بِسقُوطِ الضويء عليه.، سُُمي نسبةً

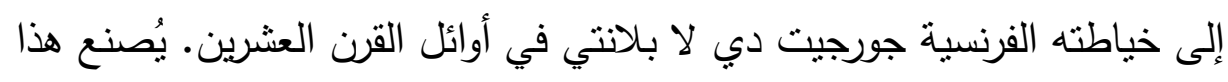

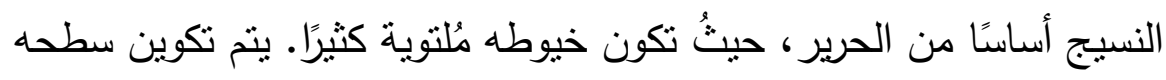
الكُتجعد المُميز عن طريق التتاوب بين خيوط S و Z في شكلٍ أعوج ومُلتحم. يصنع الجورجيت بألوانٍ وطبعاتٍ مصمتة، ويستخدم في القمصان النسائية والفساتين وفساتين السهرة، كما يُستخدم في الأوشحة. الجورجيت أكثر نعومة وأقل لمعانًا من الثيفون (جورجيت (نسيج) وكيبيديا). الملابس الخارجية للسيدات:

الملبس هو كل مايرتديه الإنسان لستر جسمه وتغطيته (عابدين، 1996)، وتشمل الملابس الخارجية للسيدات: التاييرات، الفساتين، المعاطف، الجونلات، العباءة الاندان وغيرها، ومنها مايلبس فى المساء وفى الحفلات والمناسبات الخاصة ولكل منها

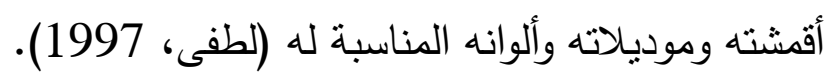

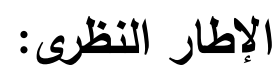
أنواع التطريز الآلى: الإطان:

1- التطريز الميكانيكى: وفيه يتم التطريز باستخدام الآله إما بطريقة طارة التطريز أو بدون استخدام طارة التطريز .

2- التطريز بالماكينات الأتوماتيكية: وظهرت تلك الماكينات نتيجة تطور صناعة ماكينات التطريز وفيه تتتج غرز التطريز بشكل أتوماتيكى بدون طارة التطريز . 3- التطريز الإكترونى: هو أحدث ما توصل إليه العلم حيث تعمل ماكينات التطريز بالكمبيوتر، وهو أسهل وأسرع طرق التطريز (ريحان، 2015). وهو

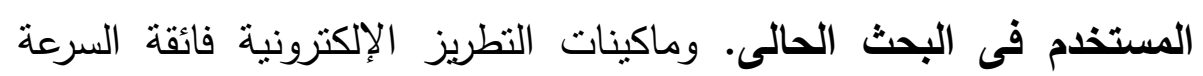


ومتعددة الرؤوس والإبر والوظائف وذات دقة وكثافة فى الإنتاج بجهد وسعر وزمن أقل ومواصفات عالية الجودة مع انخفاض نسبة العيوب بالمنتج

$$
\text { (ماضى، 2020). }
$$

\section{العوامل المؤئرة على جودة التطريز الآلى: ومنها مايلى:}

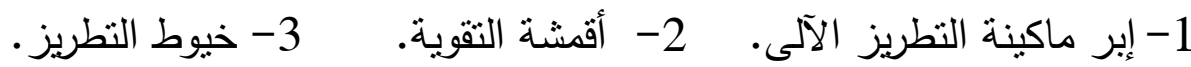

$$
\text { 4- الوحدات الزخرفية: الغرز المستخدة فى التطريز الآلى (أبو خزيم، 2019). }
$$

تتقسم الوحدات الزخرفية إلى قسمين رئيسيين هما:

1-وحدات زخرفية هندسية: هى التى يتم تكوينها من الأشكال الهندية والعلاقات

الخطية والدوائر والأشكال النجمية والمضلعات المنتظمة وغيرها.

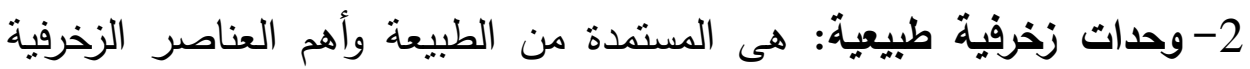

الطبيعية: العناصر النباتية، العناصر الحيوانية، العناصر الآدمية (محمد،

\section{.$(2021$

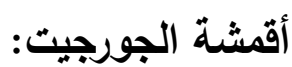

يُنسج الجورجيت باستخدام خيوط ملتوية بإحكام مما يجعله شفافًا وخفيف الوزن مع وجه غير لامع، ويُذكر أن الجورجيت ليس شفافًا بدرجة الثيفون بسبب النسج الأكثر

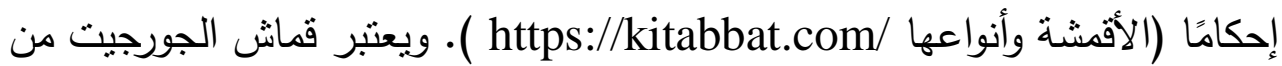
الأقمشة الخفيفة للغاية، ولكنها تعتبر أثقل بقليل من أقمشة الثيفون الناعمة للغاية، وتأتي في أسماك مختلفة ويعتمد هذا على طبيعة الاستخدام، وبستخدم بكثرة في تصميم الأزياء (أنواع_أقششة_الفساتين /https://mawdoo3.com). والجورجيت قماش انسيابي، وبفضل نسيجه الثبيه بالكريب وقوته غير العادية عند

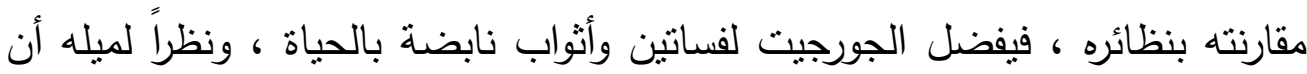
يكون ساترا ، فهذا يجعله مناسباً للعديد من النساء اللواتي يعشقن المظهر الناعم والمريح في نفس الوقت (قماش الجورجيت /https://www.almrsal.com). 
مجلة البحوث فى مجالات التربية النوعية

$$
\text { الجراءاتب التطبيقى: البحث: }
$$

1-تم اختيار الوحدة الهندية وكذلك الوحدة النباتية المستخدمتان تحت البحث من

$$
\text { رسومات للنطريز على الإنترنت. }
$$

2-نم إعداد الرسومات للنطريز الآلى بالمتغيرات المطلوبة باستخدام برنامج

و Wilcom Embroidery Studio - Level 3 Advanced

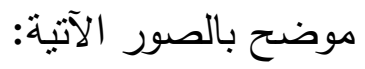

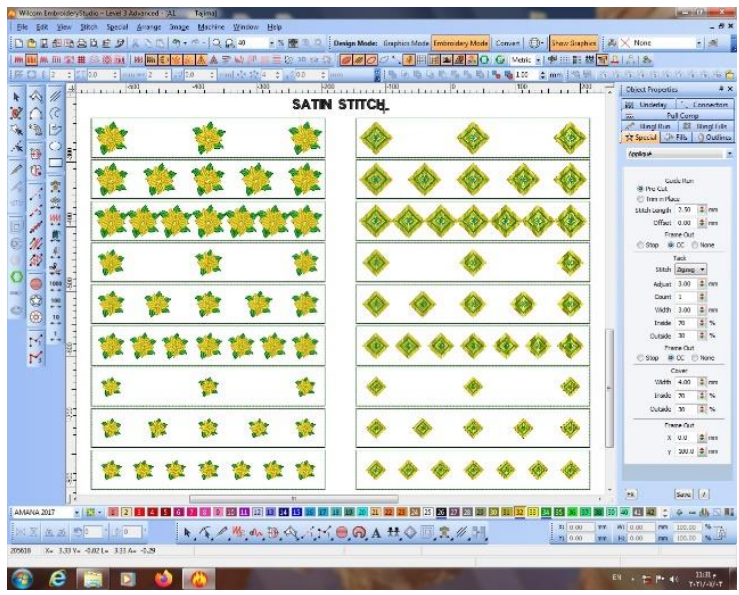

صورة (1) غززة Satin stitch بنوعين للوحدة الزخرفية، ثلاثة أحجام، ثلاثة أعداد

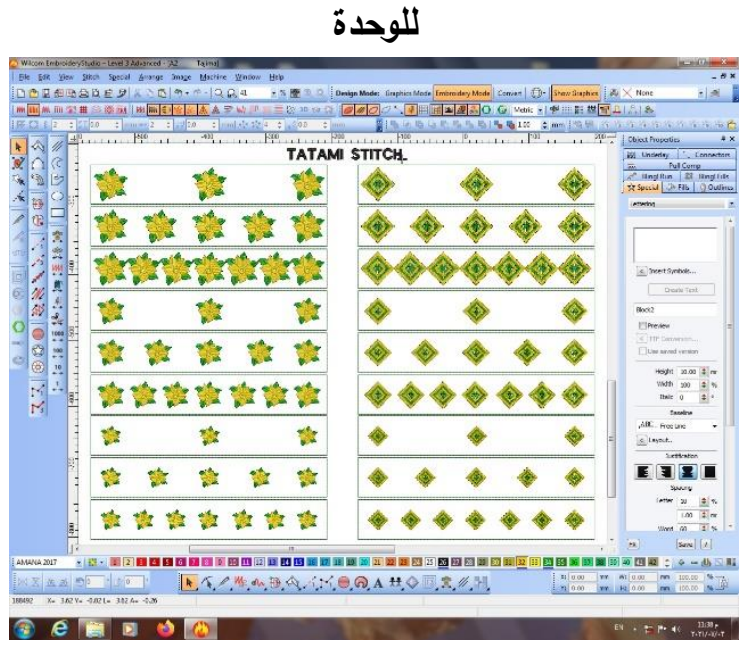

صورة (2) غززة Tatami stitch بنوعين للوحدة الزخرفية، ثلاثة أحجام، ثلاثة أعداد

$$
\text { للوحدة }
$$


مجلة البحوث في مجالات التربية النوعية

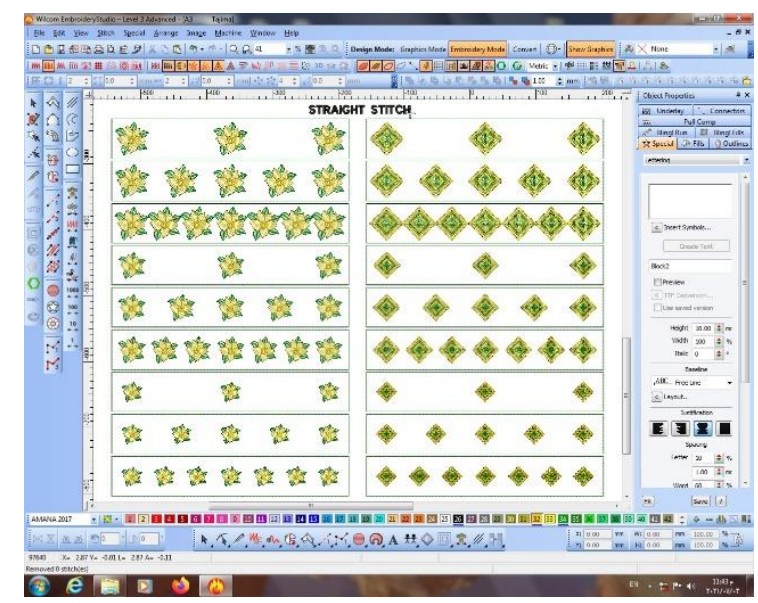

صورة (3) غرزة Straight stitch بنوعين للوحدة الزخرفية، ثلاثة أحجام، ثلاثة أعداد

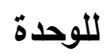

3- تم تطريز العينات تحت البحث وعددهم (54) عينة كما هو موضح بالجدول

(1) باستخدام ماكينة AKRON الصينية متعددة الرؤوس 12 رأس للنطريز الألى بالكمبيوتز الموضحة بالصورة (4).

جدول (1) العينات المطرزة تحت البحث

\begin{tabular}{|c|c|c|c|c|}
\hline فدى المساحة المطرزة الزخية & الزخرفية (سم) & نوع الوحدة & النطريز الآلى غرزة & العينة \\
\hline 3 & \multirow{3}{*}{$5 \times 5$} & \multirow{9}{*}{ 录 } & \multirow{18}{*}{ 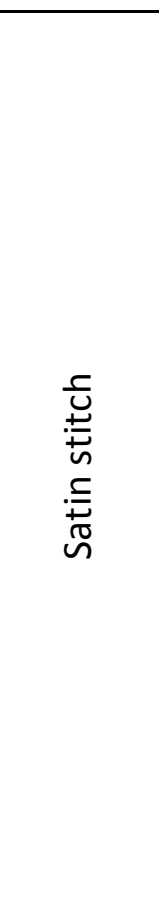 } & 1 \\
\hline 5 & & & & 2 \\
\hline 7 & & & & 3 \\
\hline 3 & \multirow{3}{*}{$4 \times 4$} & & & 4 \\
\hline 5 & & & & 5 \\
\hline 7 & & & & 6 \\
\hline 3 & \multirow{3}{*}{$3 \times 3$} & & & 7 \\
\hline 5 & & & & 8 \\
\hline 7 & & & & 9 \\
\hline 3 & \multirow{3}{*}{$5 \times 5$} & \multirow{9}{*}{$\frac{\text { 乎: }}{3:}$} & & 10 \\
\hline 5 & & & & 11 \\
\hline 7 & & & & 12 \\
\hline 3 & \multirow{3}{*}{$4 \times 4$} & & & 13 \\
\hline 5 & & & & 14 \\
\hline 7 & & & & 15 \\
\hline 3 & \multirow{3}{*}{$3 \times 3$} & & & 16 \\
\hline 5 & & & & 17 \\
\hline 7 & & & & 18 \\
\hline
\end{tabular}


مجلة البحوث في مجالات التربية النوعية

\begin{tabular}{|c|c|c|c|c|}
\hline 3 & \multirow{3}{*}{$5 \times 5$} & \multirow{9}{*}{ 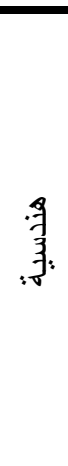 } & \multirow{18}{*}{ 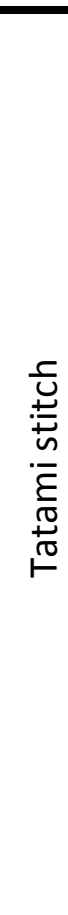 } & 19 \\
\hline 5 & & & & 20 \\
\hline 7 & & & & 21 \\
\hline 3 & \multirow{3}{*}{$4 \times 4$} & & & 22 \\
\hline 5 & & & & 23 \\
\hline 7 & & & & 24 \\
\hline 3 & \multirow{3}{*}{$3 \times 3$} & & & 25 \\
\hline 5 & & & & 26 \\
\hline 7 & & & & 27 \\
\hline 3 & \multirow{3}{*}{$5 \times 5$} & \multirow{9}{*}{ 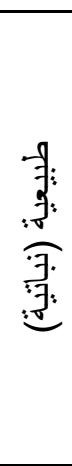 } & & 28 \\
\hline 5 & & & & 29 \\
\hline 7 & & & & 30 \\
\hline 3 & \multirow{6}{*}{$3 \times 3$} & & & 31 \\
\hline 5 & & & & 32 \\
\hline 7 & & & & 33 \\
\hline 3 & & & & 34 \\
\hline 5 & & & & 35 \\
\hline 7 & & & & 36 \\
\hline 3 & \multirow{3}{*}{$5 \times 5$} & \multirow{9}{*}{ 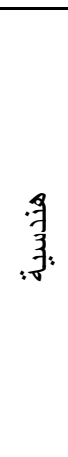 } & \multirow{18}{*}{ 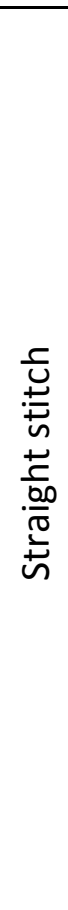 } & 37 \\
\hline 5 & & & & 38 \\
\hline 7 & & & & 39 \\
\hline 3 & \multirow{3}{*}{$4 \times 4$} & & & 40 \\
\hline 5 & & & & 41 \\
\hline 7 & & & & 42 \\
\hline 3 & \multirow{3}{*}{$3 \times 3$} & & & 43 \\
\hline 5 & & & & 44 \\
\hline 7 & & & & 45 \\
\hline 3 & \multirow{3}{*}{$5 \times 5$} & \multirow{9}{*}{ 蛹: } & & 46 \\
\hline 5 & & & & 47 \\
\hline 7 & & & & 48 \\
\hline 3 & \multirow{3}{*}{$4 \times 4$} & & & 49 \\
\hline 5 & & & & 50 \\
\hline 7 & & & & 51 \\
\hline 3 & \multirow{3}{*}{$3 \times 3$} & & & 52 \\
\hline 5 & & & & 53 \\
\hline 7 & & & & 54 \\
\hline
\end{tabular}



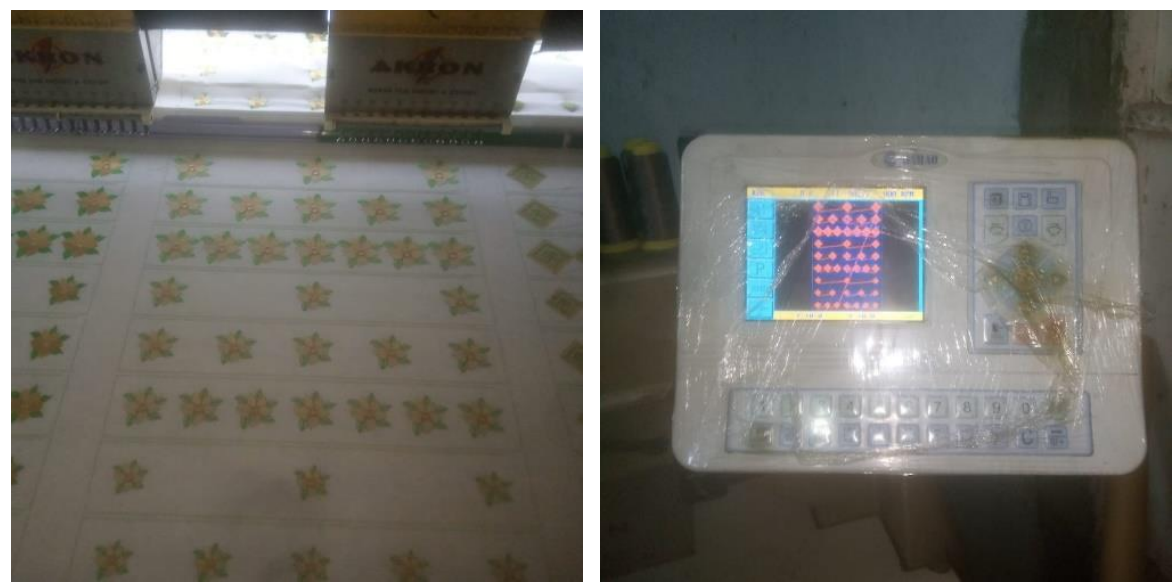

صورة (4) ماكينة التطريز الآلى المستخدمة تحت البحث

4- كانت الوحدة الهندسية المستخدمة عبارة عن شكل معين، أما الوحدة النباتية المستخدمة فكانت عبارة عن شكل زهرة، ألوان العينات كانت موحدة وهى: الأصفر الداكن (الحمصى)، الأخضر •

5- تم تطريز جميع العينات بخيط حرير ، وباستخدام نمرة إبرة 14 (نظام أمريكى). 6- وتم التطريز باستخدام بطانة من الفازلين المائى لجميع العينات تحت البحث وذلك لكون قماش الجورجيت المستخدم فى التطريز خفيف، وبعد اتمام عملية

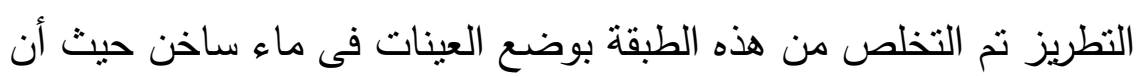
ميزة الفازلين المائى أنه يذوب فى الماء الساخن وبعدها تم غسل العينات مباشرة بماء بارد للتخلص من المادة اللاصقة (اللزوجة)، وبالتالى تم التحكم فى جودة التطريز دون أن يؤثر على المظهرية. 7- تم كى العينات تحت البحث بدرجة حرارة مناسبة لخامة الجورجيت، وكانت لتوني المساحة المطرزة (5 × 35) سم مع نرك نصف سم من جميع الاتجاهات

$$
\text { للقص عليها كما هو مبين بملحق (1). }
$$

8- قامت الباحثة بعمل استبيان موجه للمتخصصين فى مجال الملابس والنسيج للحكم على مظهرية وجودة التطريز ، واستبيان آخر موجه للمستهلكات وذلك

$$
\text { للتعرف على آرائهم عن العينات المطرزة. }
$$

9- بعد ذلك تم إجراء بعض الاختبارات الميكانيكية (قوة الثد (كجم)، نسبة الثمن

الاستطالة(\%) للعينات المطرزة تحت البحث وذلك فى اتجاه السداء لكون 
القماش المستخدم خفيف، وقد أجريت هذه الاختبارات طبقاً للمواصفة القياسية

المصرية 1962/235 باستخدام جهاز Testing Instrument, Hans Haer AG- CH, Zurich وتحت الظروف القياسية (رطوبة نسبية 65 × 2\%، ودرجة حرارة 20 × 2م) وذلك للتعرف على تأثير تقنيات التطريز الآلى المستخدمة على قوة الثد ونسبة الاستطالة لأقششة ملابس الجورجيت، ولهذا تم قياس قوة الثد ونسبة الاستطالة أيضاً لعينة من قماش الجورجيت المستخدم بدون تطريز (عينة ضابطة) وذلك للمقارنة.

10- بعد الحصول على نتائج الاستبيان الموجه للمتخصصين والاستبيان

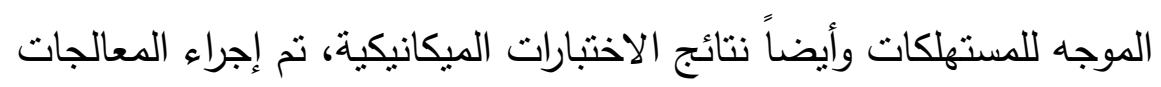
الاحصائية باستخدام البرنامج الاحصائي Spss الاصدار الحادي والعشرون.

تقنين الأدوات (الصدق والثبات)

أولاً: استبيان تقييم العينات المطرزة لأثمشة الملابس الخفيفة وفقاً لآراء

تم إعداد استبيان موجه للمتخصصين بمجال الملابس والنسيج - لتحكيم العينات المطرزة لأقشة الملابس الخفيفة (الجورجيت) وتتضمن الاستبيان علي أربع محاور : المحور الأول: نوع غرزة النطريز الآلى وتضمن (4) عبارات. المحور الثاني: حجم الوحدة الزخرفية وتضمن (3) عبارات. المحور الثالث: عدد الوحدات الزخرفية وتضمن (3) عبارات. المحور الرابع: نوع الوحدة الزخرفية المستخدمة وتضمن (3) عبارات. وقد استخدم ميزان تقدير ليكرت ثلاثي المستويات بحيث تعطي الاجابة مناسب (تثلاث درجات)، مناسب إلي حد ما (درجتان)، غير مناسب (درجة)، وكانت درجة المحور الأول (12) درجة، والمحور الثاني (9) درجة، كانت درجة المحور الثالث (9) درجة، كانت درجة المحور الرابع (9) درجة، وكانت الدرجة الكلية للاستبيان (39) درجة. 
صدق محتوي الاستبيان: صدق المتخصصين: ويقصد به قدرة الاستبيان علي قياس ما وضع لقياسه. وللتحقق من صدق محتوي الاستبيان تم عرضه في صورته المبئية علي مجموعة من المتخصصين من أساتذة الملابس والنسيج، وبلغ عددهم (10) وذلك للحكم علي مدي مناسبة كل عبارة للمحور الخاص به، وكذلك صباغة العبارات وتحديد وإضافة أي عبارات مقترحة، وقد تم التعديل بناء علي آراء المتخصصين كما هو موضح بالجدول التالي: جدول (2) معامل اتفاق المتخصصين علي استبيان تقييم العينات المطرزة لأقمشة الملابس الجورجيت

\begin{tabular}{|c|c|c|c|}
\hline الاتفاق & عدات مرات عدم & علد مرات & بنود التحكيم \\
\hline $100 \%$ & 0 & 10 & سلامة الصياغة اللغوية للعبارات. \\
\hline $100 \%$ & 0 & 10 & سلامة الصياغة العلمية للعبارات. \\
\hline $90 \%$ & 1 & 9 & تناسب المحاور مع هدف الاستبانة \\
\hline $90 \%$ & 1 & 9 & تناسب العبارات وتسلسلها المنطقي مع المحور. \\
\hline
\end{tabular}

استخدمت الباحثة طريقة اتفاق المتخصصين البالغ عددهم (10) في حساب ثبات الملاحظين لتحديد بنود التحكيم التي يتم تتفيذها بشرط أن يسجل كل منهم ملاحظاته مستقلا عن الأخر، وتم تحديد عدد مرات الاتفاق بين الملاحظين باستخدام معادلة

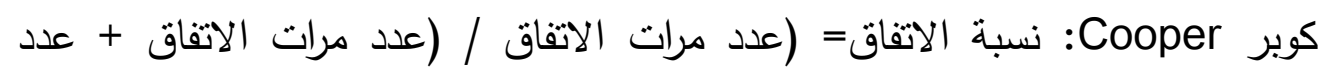

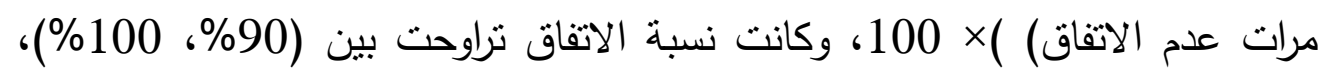
وهي نسب اتفاق مقبولة. الصدق باستخدام الاتساق الاخلي بين الدرجة الكلية لكل محور والدرجة الكلية لناستبيان: تم حساب الصدق باستخدام الاتساق الداخلي وذللك بحساب معامل ارتباط بيرسون بين الدرجة الكلية لكل محور والدرجة الكلية للاسنبيان، والجدول التالي يوضح ذلك: 
جدول(3): قيم معاملات الارتباط بين درجة كل محور ودرجة الاستبيان

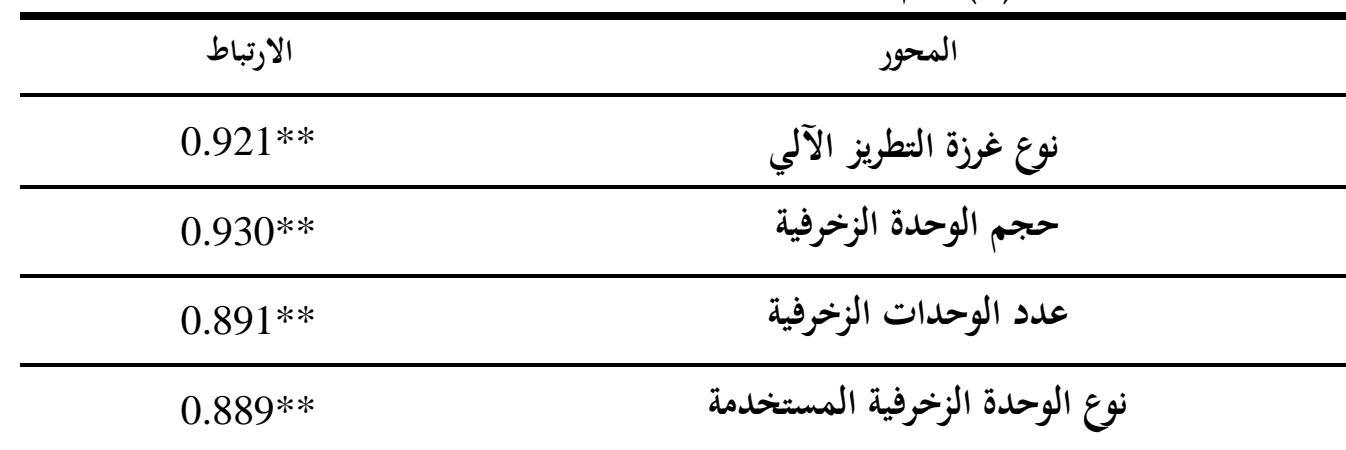

يتضح من جدول (3) أن معاملات الارتباط كلها دالة عند مستوي (0.01) لاقترابها من الواحد الصحيح، ومن ثم يمكن القول أن هنالك اتساقا داخلياً بين المحاور المكونة لهذا الاستبيان، كما أنه يقيس بالفعل ما وضع لقياسه، مما يدل علي صدق وتجانس

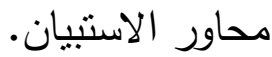

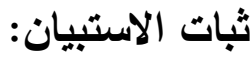
يقصد بالثبات دقة الاختبار في القياس والملاحظة، وعدم تتاقضه مع نفسه، وهو النسبة بين تباين الدرجة علي المقياس التي تشير إلي الأداء الفعلي للفحوص، وتم حساب Alpha Cronbach الثبات عن طريق معامل ألفا كرونباخ لبن جدول(4): قيم معامل الثبات لمحاور الاستبيان

\begin{tabular}{|c|c|}
\hline معامل ألفا & 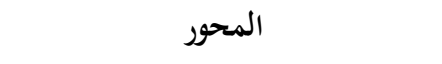 \\
\hline $0.901 * *$ & نوع غرزة التطريز الآلي \\
\hline $0.925^{* *}$ & حجم الوحدة الزخرفية \\
\hline $0.891 * *$ & عدد الوحدات الزخرفية \\
\hline $0.886^{* *}$ & نوع الوحدة الزخرفية المستخدمة \\
\hline $0.900 * *$ & ثبات الاستبيان (ككل) \\
\hline
\end{tabular}

يتضح من جدول (4) أن جميع قيم معاملات الثبات، دالة عند مستوي (0.01) مما يدل علي ثبات الاستبيان. 
ثانياً: استبيان تقييم العينات المطرزة لأقمشة الملابس الخفيفة وفقاً لآراء

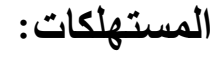

تم إعداد استبيان موجه للمستهلكات - للتعرف على آرائهن فى العينات المطرزة لأقشة الملابس الخفيفة (الجورجيت) وتضمن الاستبيان علي (8) عبارات وقد استخدم ميزان تقدير ليكرت ثلاثي المستويات بحيث تعطي الاجابة مناسب (ثلاث درجات)، مناسب إلي حد ما (درجتان)، غير مناسب (درجة)، وكانت الدرجة الكلية للاستبيان (24) - 20 (24) درجة. صدق محتوي الاستبيان: ويقصد به قدرة الاستبيان علي قياس ما وضع لقياسه. وللتحقق من صدق محتوي الاستبيان تم عرضه في صورته المبدئية علي مجموعة من المتخصصين من أساتذة الملابس والنسيج، وبلغ عددهم (10) وذللك للحكم علي مدي مناسبة كل عبارة، وكذلك صياغة العبارات وتحديد وإضافة أي عبارات مقترحة، وقد تم التعديل كما هو موضح بالجدول التالي:

جدول (5) معامل اتفاق السادة المتخصصين علي بنود استبيان تقييم العينات المطرزة لأقمشة الملابس الجورجيث

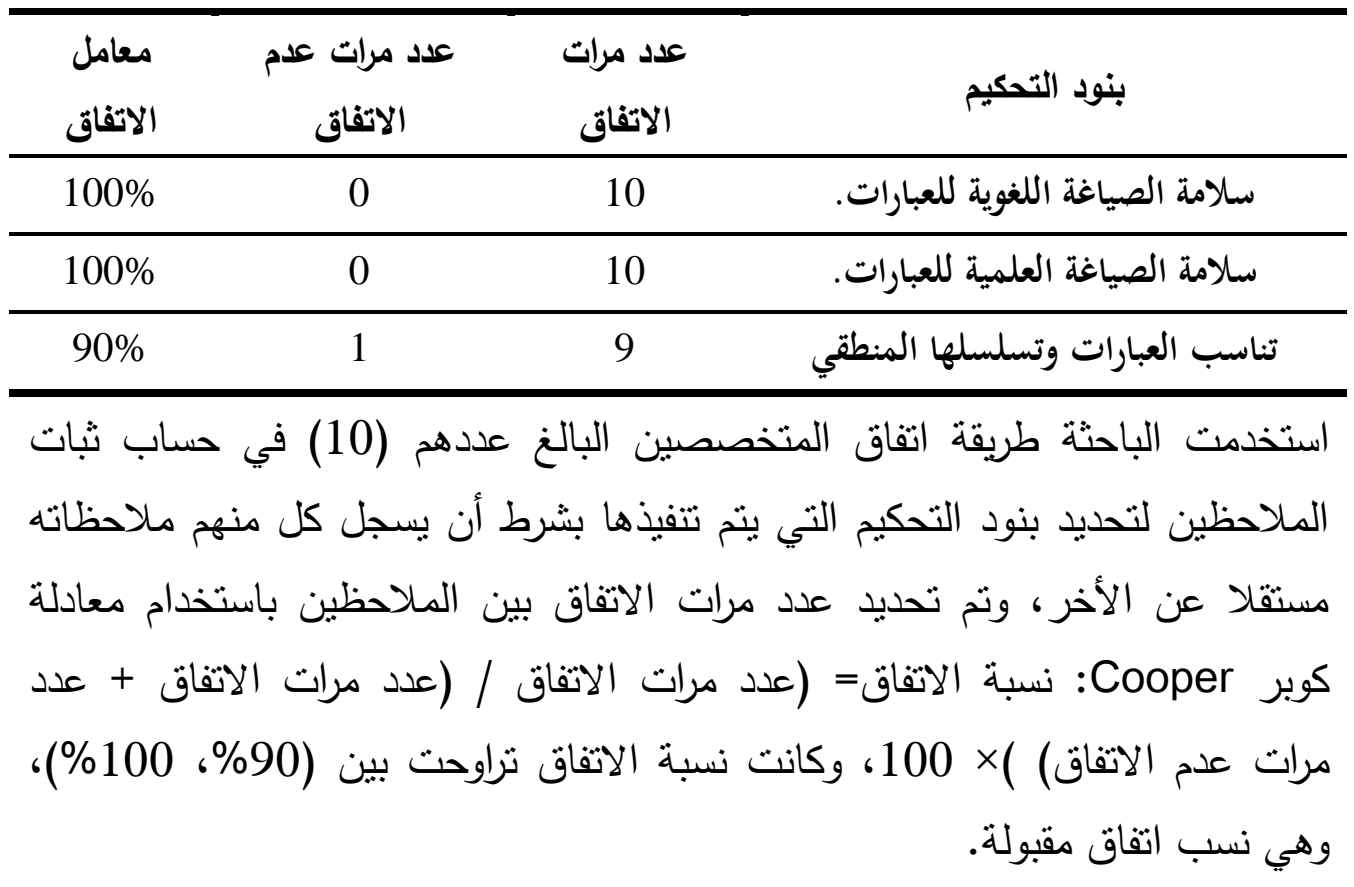


الصدق باستخدام الاتساق الداخلي بين درجة كل عبارة والدرجة الكلية للاستبيان: تم حساب الصدق باستخدام الاتساق الداخلي وذلك بحساب معامل الارتباط بيرسون بين درجة كل عبارة، والدرجة الكلية للاستبيان، والجدول التالي يوضح ذلك: جدول (6) قيم معاملات الارتباط بين درجة كل عبارة ودرجة الاستبيان

\begin{tabular}{|c|c|}
\hline 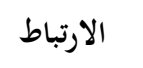 & 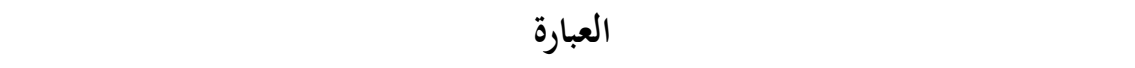 \\
\hline $0.903^{\star *}$ & تظهر الغززة بوضوح فى الوحدة المطرزة. \\
\hline $0.983^{\star \star}$ & يوجد دقة فى تطريز القطعة باستخذام هذا النوع من الغرز. \\
\hline $0.964^{\star \star}$ & تعطى غرزة التطريز جمالا للوحدة المطرزة. \\
\hline $0.930^{\star *}$ & يتناسب حجم الوحدة الزخرفية مع طبيعة أقمشة ملابس السبدات الخارجية الخفيفة. \\
\hline $0.916^{\star *}$ & يظهر جمال التطريز باستخدام هذا الحجم للوحدة الزخرفية. \\
\hline $0.938^{\star \star}$ & يفضل هذا العدد من الوحدات لتغطية المساحة المطرزة. \\
\hline $0.920^{\star \star}$ & تتلاعم الوحدة الزخرفية مع خامة الجورجيت الخفيفة. \\
\hline $0.901^{\star *}$ & يفضل هذا النوع من الوحدات لتطريز الفساتين المسائية للفتيات والسيدات من عمر (20- \\
\hline
\end{tabular}

يكثف الجدول السـابق أن معاملات الارتباط كلها دالة عند مستوي (0.01) لاقترابها

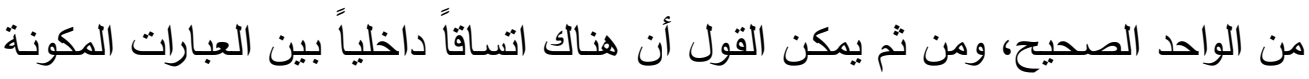

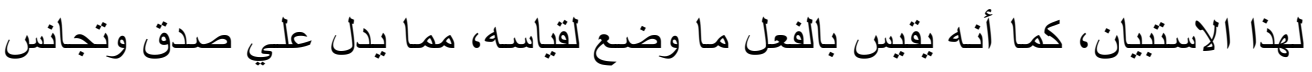
محاور الاستبيان.

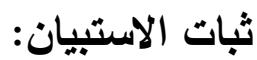

يقصد بالثبات دقة الاختبار في القياس والملاحظة، وعدم تتاقضه مع نفسه، وهو النسبة بين تباين الدرجة علي المقياس التي تتبير إلي الأداء الفعلي للمفحوص، وتم وتم حساب الثبات عن طريق معامل ألفا كرونباخ Alpha Cronbach، وطريقة التجزئة النصفية .Split - half

جدول (7) قيم معامل الثبات لمحاور الاستبيان

\begin{tabular}{|c|c|c|}
\hline التجزئة النصفية & معامل ألفا & \\
\hline $0.924-0.867$ & $0.911^{\star *}$ & ثبات الاستبيان ككل \\
\hline
\end{tabular}

تم حسـاب ثبات الاستبيان بمعامل ارتباط ألفا فكانت قيمته (0.911) وهي

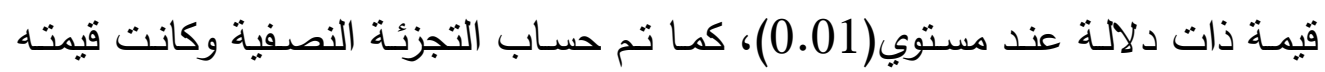


(0.867- 0.924) وهـي قيمـة ذات دلالــة عنــ مسـتوي(0.01) ممـا يشـير إلـي أن

الاستنيان يتمتع بدرجة عالية من الثبات.

النتائج والمناقشة:

أولاً: نتائج استبيان تقييم عينات أقمشة الملابس الخفيفة وفقاً لآراء المتخصصين: الفرض الأول: توحد فروق ذات دلالة إحصائية بين نوع غرزة التطريز الآلي لعينات أقمشة الملابس الخفيفة وفقاً لآراء المتخصصين. وللتحقق من صحة هذا الفرض نم حساب تحليل التباين لمتوسط تقييم عينات أقمشة الملابس الخفيفة (الجورجيت) وفقاً لنوع غرزة التطريز الآلي في ضوء آراء المتخصصين وجدول (8) يوضح ذلك: جلول(8): تحليل التباين لمتوسط تقييم عينات أقمشة الملابس الجورجيت وفقاً لنوع غرزة التطريز الآلي في ضوء آراء المتخصصين

\begin{tabular}{|c|c|c|c|c|c|c|}
\hline الدلالة & قيمة ف & متوسط المربعات & الحرجة & مجموع المربعات & مصدر التباين & \\
\hline \multirow{3}{*}{.000} & \multirow{3}{*}{3.618} & 14.641 & 53 & 775.981 & بين المجموعات & \multirow{3}{*}{ العينات } \\
\hline & & 4.046 & 162 & 655.500 & داخل المجموعات & \\
\hline & & & 215 & 1431.481 & التباين الكلي & \\
\hline \multirow{3}{*}{.000} & \multirow{3}{*}{93.169} & 333.977 & 2 & 667.954 & بين المجموعات & \multirow{3}{*}{ التطريز الآلي } \\
\hline & & 3.585 & 213 & 763.528 & داخل المجموعات & \\
\hline & & & 215 & 1431.481 & التباين الكلي & \\
\hline
\end{tabular}

1. وجود فرق دال إحصائياً عند مستوي (0.01) بين عينات أقشة الملابس الخفيفة (الجورجيت) وفقاً لآراء المتخصصين حيث قيمة (ف) كانت (3.618) وهي قيمة دالة إحصائياً. 2. وجود فرق دال إحصائياً عند مستوي (0.01) بين نوع غرزة التطريز الآلي لعينات أقمشة الملابس الخفيفة (الجورجيت) وفقاً لآراء المتخصصين حيث لهيث قيمة (ف) كانت (93.169) وهي قيمة دالة إحصائياً. 


\section{مجلة البحوث فى مجالات التربية النوعية}

والجدول التالي يوضح المتوسطات ومعامل الجودة لعينات أقمشة الملابس الخفيفة (الجورجيت) وفقاً لآراء المتخصصين.

جدول(9): المتوسطات والانحراف المعيارى ومعامل الجودة لعينات أقمشة الملابس الجورجيت

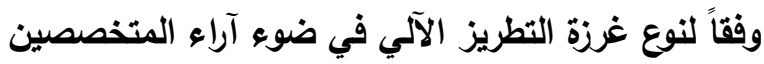

\begin{tabular}{|c|c|c|c|c|c|c|c|c|}
\hline التصميمات & الجودة & الانحراف & المتوسط & عدا الزخرفية فى الوحدات & الوحجدة & الونوة الزخدة & نوع غرزة & العينة \\
\hline 3 & 97.50 & 0.96 & 29.25 & 3 & \multirow{3}{*}{$5 \times 5$} & \multirow{9}{*}{ 争 } & \multirow{18}{*}{ 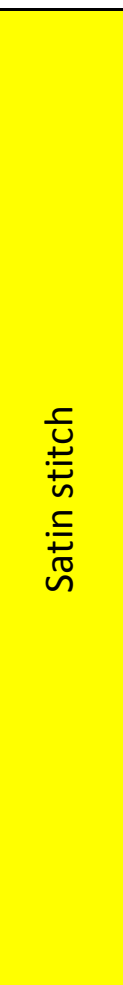 } & 1 \\
\hline 5 & 95.83 & 1.50 & 28.75 & 5 & & & & 2 \\
\hline 8 & 93.33 & 2.31 & 28.00 & 7 & & & & 3 \\
\hline 2 & 98.33 & 0.58 & 29.50 & 3 & \multirow{3}{*}{$4 \times 4$} & & & 4 \\
\hline 4 & 96.67 & 1.15 & 29.00 & 5 & & & & 5 \\
\hline 7 & 94.17 & 2.06 & 28.25 & 7 & & & & 6 \\
\hline 1 & 100.00 & 0.00 & 30.00 & 3 & \multirow{3}{*}{$3 \times 3$} & & & 7 \\
\hline 3 & 97.50 & 0.96 & 29.25 & 5 & & & & 8 \\
\hline 6 & 95.00 & 1.91 & 28.50 & 7 & & & & 9 \\
\hline 7 & 94.17 & 1.71 & 28.25 & 3 & \multirow{3}{*}{$5 \times 5$} & \multirow{9}{*}{ 䙢: } & & 10 \\
\hline 9 & 92.50 & 2.22 & 27.75 & 5 & & & & 11 \\
\hline 12 & 90.00 & 2.94 & 27.00 & 7 & & & & 12 \\
\hline 6 & 95.00 & 1.29 & 28.50 & 3 & \multirow{3}{*}{$4 \times 4$} & & & 13 \\
\hline 8 & 93.33 & 1.83 & 28.00 & 5 & & & & 14 \\
\hline 11 & 90.83 & 2.63 & 27.25 & 7 & & & & 15 \\
\hline 5 & 95.83 & 0.96 & 28.75 & 3 & \multirow{3}{*}{$3 \times 3$} & & & 16 \\
\hline 7 & 94.17 & 1.50 & 28.25 & 5 & & & & 17 \\
\hline 10 & 91.67 & 2.38 & 27.50 & 7 & & & & 18 \\
\hline 12 & 90.00 & 1.41 & 27.00 & 3 & \multirow{3}{*}{$5 \times 5$} & \multirow{9}{*}{. } & \multirow{10}{*}{ 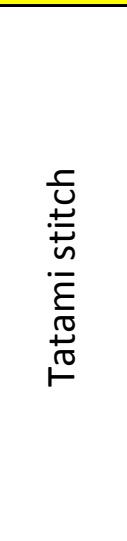 } & 19 \\
\hline 14 & 88.33 & 1.91 & 26.50 & 5 & & & & 20 \\
\hline 17 & 85.83 & 2.63 & 25.75 & 7 & & & & 21 \\
\hline 11 & 90.83 & 0.96 & 27.25 & 3 & \multirow{3}{*}{$4 \times 4$} & & & 22 \\
\hline 13 & 89.17 & 1.50 & 26.75 & 5 & & & & 23 \\
\hline 16 & 86.67 & 2.31 & 26.00 & 7 & & & & 24 \\
\hline 10 & 91.67 & 0.58 & 27.50 & 3 & \multirow{3}{*}{$3 \times 3$} & & & 25 \\
\hline 12 & 90.00 & 1.15 & 27.00 & 5 & & & & 26 \\
\hline 15 & 87.50 & 2.06 & 26.25 & 7 & & & & 27 \\
\hline 16 & 86.67 & 2.16 & 26.00 & 3 & $5 \times 5$ & 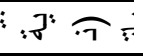 & & 28 \\
\hline
\end{tabular}


مجلة البحوث فى مجالات التربية النوعية

\begin{tabular}{|c|c|c|c|c|c|c|c|c|}
\hline 18 & 85.00 & 2.65 & 25.50 & 5 & \multirow{5}{*}{$4 \times 4$} & & & 29 \\
\hline 21 & 82.50 & 3.30 & 24.75 & 7 & & & & 30 \\
\hline 15 & 87.50 & 1.71 & 26.25 & 3 & & & & 31 \\
\hline 17 & 85.83 & 2.22 & 25.75 & 5 & & & & 32 \\
\hline 20 & 83.33 & 2.94 & 25.00 & 7 & & & & 33 \\
\hline 14 & 88.33 & 1.29 & 26.50 & 3 & \multirow{3}{*}{$3 \times 3$} & & & 34 \\
\hline 16 & 86.67 & 1.83 & 26.00 & 5 & & & & 35 \\
\hline 19 & 84.17 & 2.63 & 25.25 & 7 & & & & 36 \\
\hline 21 & 82.50 & 1.89 & 24.75 & 3 & \multirow{3}{*}{$5 \times 5$} & \multirow{9}{*}{ 忽 } & \multirow{18}{*}{ 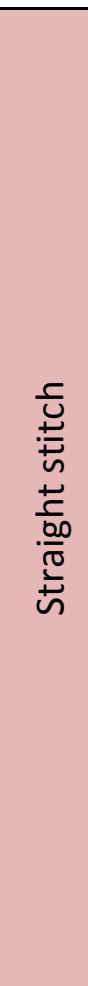 } & 37 \\
\hline 23 & 80.83 & 2.36 & 24.25 & 5 & & & & 38 \\
\hline 25 & 79.17 & 2.87 & 23.75 & 7 & & & & 39 \\
\hline 20 & 83.33 & 1.41 & 25.00 & 3 & \multirow{3}{*}{$4 \times 4$} & & & 40 \\
\hline 22 & 81.67 & 1.91 & 24.50 & 5 & & & & 41 \\
\hline 24 & 80.00 & 2.45 & 24.00 & 7 & & & & 42 \\
\hline 19 & 84.17 & 0.96 & 25.25 & 3 & \multirow{3}{*}{$3 \times 3$} & & & 43 \\
\hline 21 & 82.50 & 1.50 & 24.75 & 5 & & & & 44 \\
\hline 23 & 80.83 & 2.06 & 24.25 & 7 & & & & 45 \\
\hline 24 & 80.00 & 2.16 & 24.00 & 3 & \multirow{3}{*}{$5 \times 5$} & \multirow{9}{*}{ 寻: } & & 46 \\
\hline 26 & 78.33 & 2.65 & 23.50 & 5 & & & & 47 \\
\hline 27 & 76.67 & 3.16 & 23.00 & 7 & & & & 48 \\
\hline 23 & 80.83 & 1.71 & 24.25 & 3 & \multirow{3}{*}{$4 \times 4$} & & & 49 \\
\hline 25 & 79.17 & 2.22 & 23.75 & 5 & & & & 50 \\
\hline 27 & 77.50 & 2.75 & 23.25 & 7 & & & & 51 \\
\hline 22 & 81.67 & 1.29 & 24.50 & 3 & \multirow{3}{*}{$3 \times 3$} & & & 52 \\
\hline 24 & 80.00 & 1.83 & 24.00 & 5 & & & & 53 \\
\hline 26 & 78.33 & 2.38 & 23.50 & 7 & & & & 54 \\
\hline 1 & 94.77 & 1.73 & 28.43 & & \multicolumn{3}{|c|}{ Satin stitch } & نوع \\
\hline 2 & 87.22 & 1.96 & 26.17 & & \multicolumn{3}{|c|}{ Tatami stitch } & غرزة \\
\hline 3 & 80.42 & 1.98 & 24.13 & & \multicolumn{2}{|c|}{ Straight stitch } & & الآلى \\
\hline
\end{tabular}




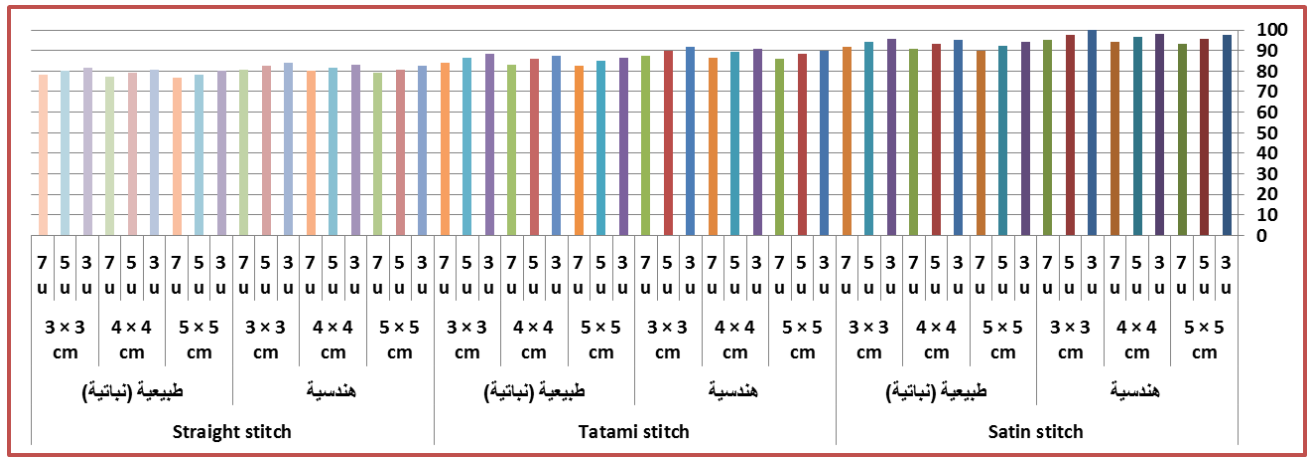

شكل (1) معامل الجودة لتقييم عينات أقمشة الملابس الجورجيت وفقاً لنوع غرزة التطريز الآلي

في ضوء آراء المتخصصين

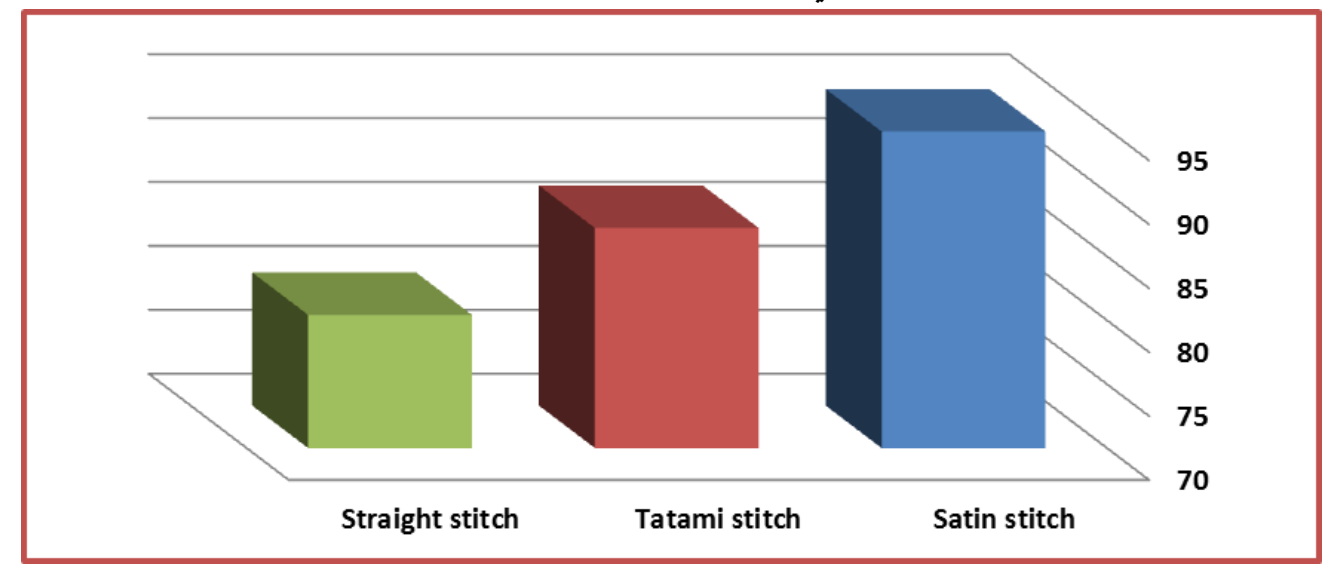

شكل (2) معامل الجودة لنوع غرزة التطريز الآلي لعينات أقشة الملابس الجورجيت في ضوء آراء

$$
\text { من الجدول (9) والثكل (1) والثكل (2) بتضح أن: }
$$

ل أفضل عينات أقمشة الملابس الخفيفة (الجورجيت) وفقاً لنوع غرزة التطريز الآلي هي (العينة: رقم 7) بنوع غرزة التطريز (Satin stitch) ووحدة زخرفية

$$
\text { (هندسية)، وحجم الوحدة (3×3 سم) وعدد الوحدات المستخدمة (3 وحدات). }
$$

ل أقل عينات أقششة الملابس الخفيفة (الجورجيت) وفقاً لنوع غرزة التطريز الآلي هي (العينة: رقم 48، 51) بنوع غرزة النطريز (Straight stitch) ووحدة زخرفية (طبيعية)، وحجم الوحدة (5×5 سم، 4×4 سم) علي الترتيب وعدد

$$
\text { الوحدات المستخدمة (7 وحدات). }
$$

ل ترنيب نوع غرزة التطريز الآلي لعينات أقشة الملابس الخفيفة (الجورجيت) وفقاً لآراء المتخصصين Satin stitch، يليها Tatami stitch، يليها 
Straight stitch والتى توصلت لوجود فروق ذات دلالة إحصائية لنوع غرزة التطريز لمحاور التقييم (ككل) فى تأثيره على مظهرية العينات المنفذة لصالح غرزة الساتان

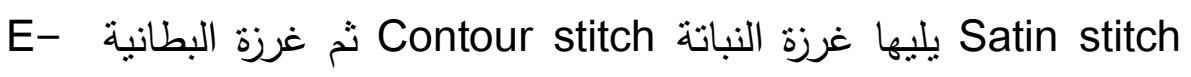
stitch

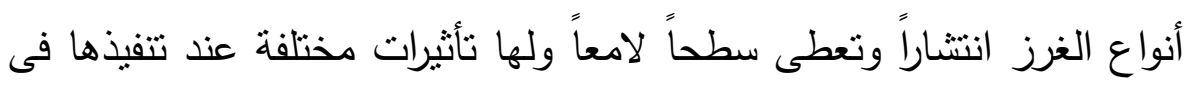
اتجاهات مختلفة بشكل مستدير ، بيضاوى، مدبب.

وفي ضوء ما سبق بمكن قبول الفرض الأول من فروض البحث والذي ينص على إني: توجد فروق ذات دلالة إحصائية بين نوع غرزة التطريز الآلي لعينات أقمشة الملابس الخفيفة وفقاً لآراء المتخصصين. القرض الثاني: توجد فروق ذات دلالة إحصائية بين نوع الوحدة الزخرفية لعينات أقششة الملابس الخففةة وفقاً لآراء المتخصصين: وللتحقق من صحة هذا الفرض نم حساب تحليل التباين لمتوسط تقييم عينات أقششة الملابس الخفيفة (الجورجيت) وفقاً لنوع الوحدة الزخرفية في ضوء آراء المتخصصين وجدول (10) يوضح ذللك:

جدول(10): تحليل التباين لمتوسط تقييم عينات أقششة الملابس الجورجيت وفقاً لنوع الوحدة

\begin{tabular}{|c|c|c|c|c|c|c|}
\hline \multicolumn{7}{|c|}{ الزخرفية في ضوء آراء المتخصصين } \\
\hline الدلالة & قيمة ف & متوسط & درجة & مجموع المربعات & مصدر التباين & \\
\hline & & & & & & \\
\hline \multirow{3}{*}{.000} & \multirow{3}{*}{24.639} & 15.666 & 53 & 830.272 & بين المجموعات & \multirow{3}{*}{ 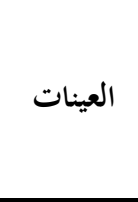 } \\
\hline & & .636 & 108 & 68.667 & داخل المجموعات & \\
\hline & & & 161 & 898.938 & التباين الكلي & \\
\hline \multirow{3}{*}{.000} & \multirow{3}{*}{37.341} & 170.099 & 1 & 170.099 & بين المجموعات & \multirow{3}{*}{ نوع الزخحفية } \\
\hline & & 4.555 & 160 & 728.840 & داخل المجموعات & \\
\hline & & & 161 & 898.938 & التباين الكلي & \\
\hline
\end{tabular}


1. وجود فرق دال إحصائياً عند مستوي (0.01) بين عينات أقمشة الملابس الخفيفة (الجورجيت) وفقاً لآراء المتخصصين حيث قيمة (ف) كانت

$$
\text { (24.639) وهي قيمة دالة إحصائياً. }
$$

2. وجود فرق دال إحصائياً عند مستوي (0.01) بين نوع الوحدة الزخرفية لعينات

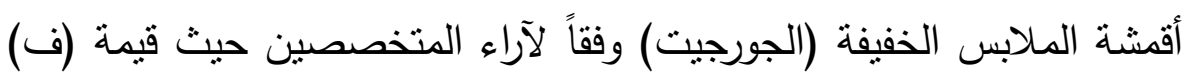

$$
\text { كانت (37.341) وهي قيمة دالة إحصائياً. }
$$

والجدول التالي يوضح المتوسطات ومعامل الجودة لعينات أقششة الملابس الخفيفة (الجورجيت) وفقاً لآراء المتخصصين.

جدول(11): المتوسطات والانحراف المعيارى ومعامل الجودة لعينات أقشة الملابس الجورجيت

\begin{tabular}{|c|c|c|c|c|c|c|c|c|}
\hline التصميمات & الجودة & الانحعياري & المتوسط & عدد الوحدات & الزحجدة & الزوحدة الزخرفية & نوع غرزة النطريز & العينة \\
\hline 9 & 85.56 & 0.58 & 25.67 & 3 & \multirow{3}{*}{$5 \times 5$} & \multirow{9}{*}{ : } & \multirow{18}{*}{ 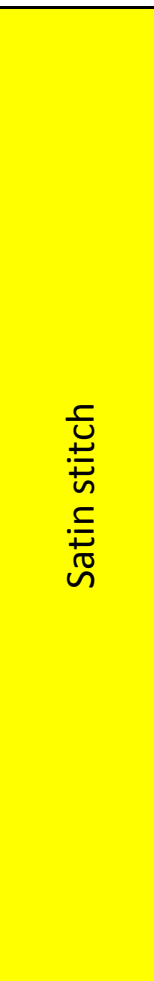 } & 1 \\
\hline 11 & 81.11 & 0.58 & 24.33 & 5 & & & & 2 \\
\hline 14 & 76.67 & 1.00 & 23.00 & 7 & & & & 3 \\
\hline 5 & 92.22 & 0.58 & 27.67 & 3 & \multirow{3}{*}{$\begin{array}{c}\times 4 \\
4\end{array}$} & & & 4 \\
\hline 8 & 87.78 & 0.58 & 26.33 & 5 & & & & 5 \\
\hline 10 & 82.22 & 1.15 & 24.67 & 7 & & & & 6 \\
\hline 1 & 100.00 & 0.00 & 30.00 & 3 & \multirow{3}{*}{$\begin{array}{c}\times 3 \\
3\end{array}$} & & & 7 \\
\hline 3 & 95.56 & 0.58 & 28.67 & 5 & & & & 8 \\
\hline 6 & 91.11 & 1.15 & 27.33 & 7 & & & & 9 \\
\hline 13 & 78.89 & 0.58 & 23.67 & 3 & \multirow{3}{*}{$\begin{array}{c}\times 5 \\
5\end{array}$} & \multirow{9}{*}{ 寻: } & & 10 \\
\hline 16 & 74.44 & 0.58 & 22.33 & 5 & & & & 11 \\
\hline 17 & 70.00 & 1.00 & 21.00 & 7 & & & & 12 \\
\hline 9 & 85.56 & 0.58 & 25.67 & 3 & \multirow{3}{*}{$\begin{array}{c}\times 4 \\
4\end{array}$} & & & 13 \\
\hline 11 & 81.11 & 0.58 & 24.33 & 5 & & & & 14 \\
\hline 15 & 75.56 & 1.15 & 22.67 & 7 & & & & 15 \\
\hline 5 & 92.22 & 0.58 & 27.67 & 3 & \multirow{3}{*}{$\begin{array}{c}\times 3 \\
3\end{array}$} & & & 16 \\
\hline 8 & 87.78 & 0.58 & 26.33 & 5 & & & & 17 \\
\hline 10 & 82.22 & 1.15 & 24.67 & 7 & & & & 18 \\
\hline 9 & 85.56 & 0.58 & 25.67 & 3 & \multirow{2}{*}{$\begin{array}{c}\times 5 \\
5\end{array}$} & \multirow{2}{*}{ : } & \multirow{2}{*}{ 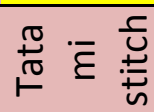 } & 19 \\
\hline 12 & 80.00 & 1.00 & 24.00 & 5 & & & & 20 \\
\hline
\end{tabular}

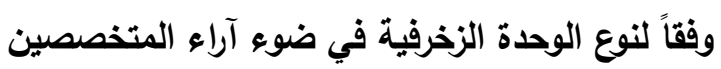


مجلة البحوث فى مجالات التربية النوعية

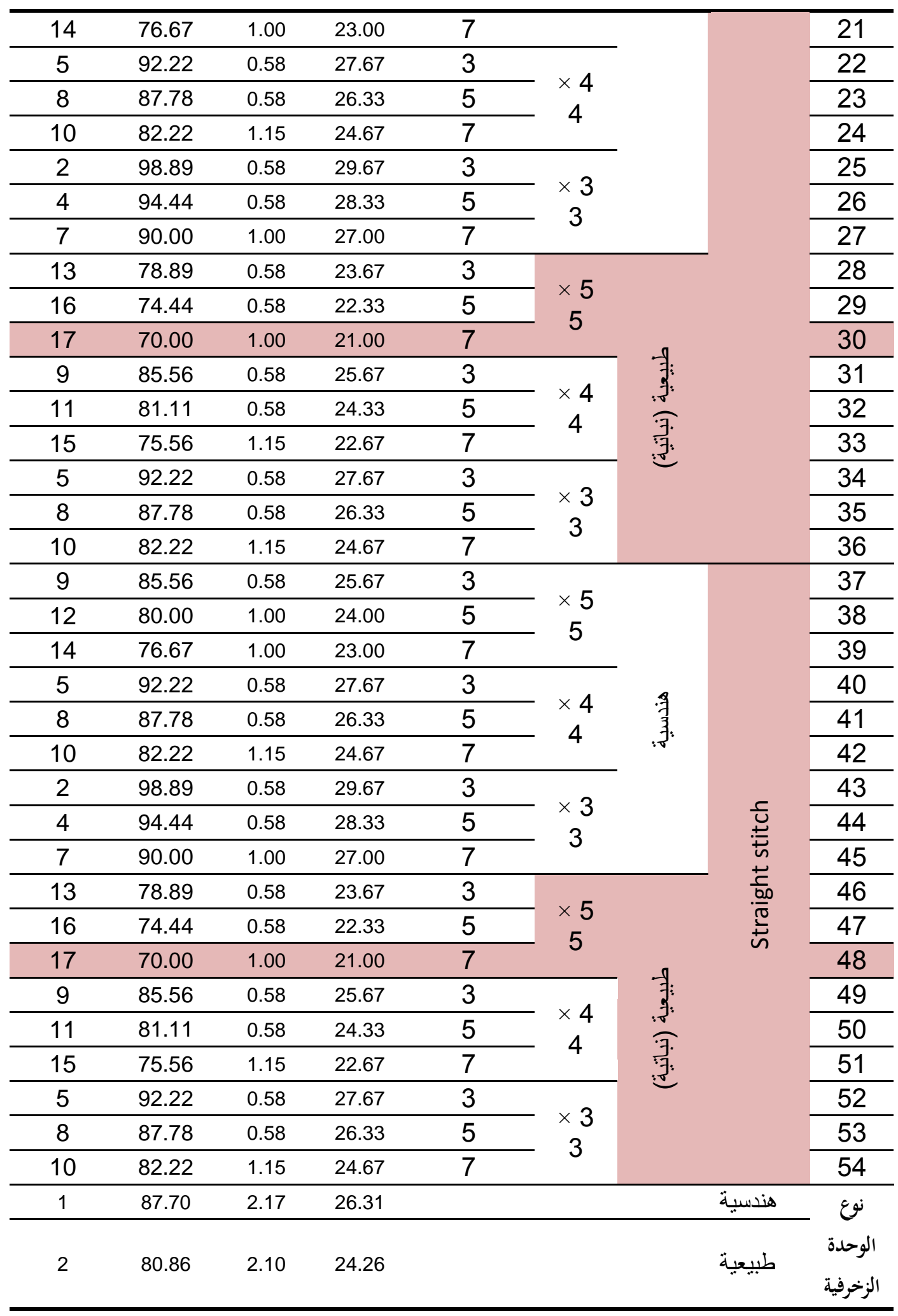




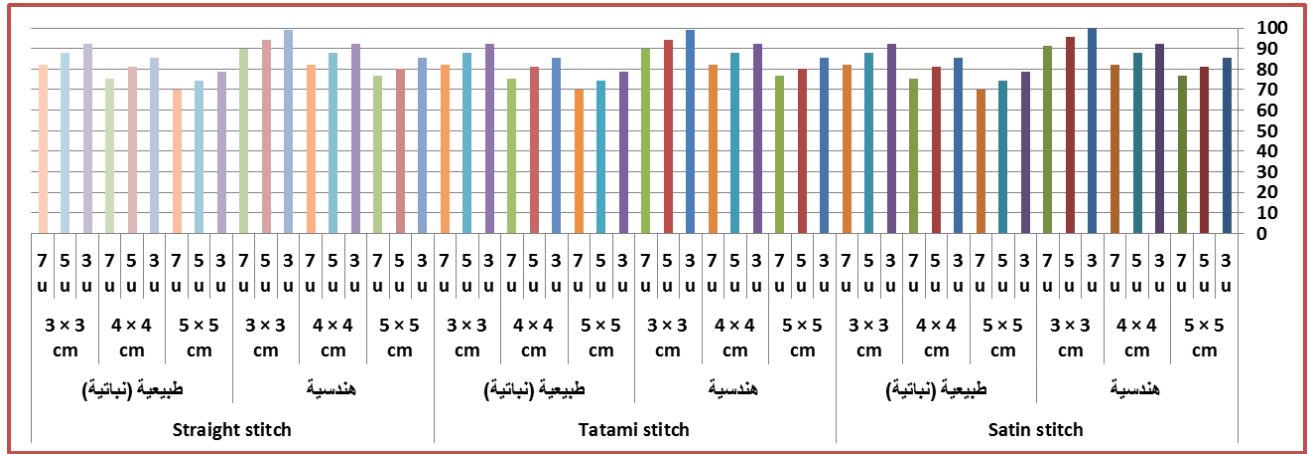

شكل (3) معامل الجودة لتقييم عينات أقششة الملابس الجورجيت وفقاً لنوع الوحدة الزخرفية في ضوء آراء المتخصصين

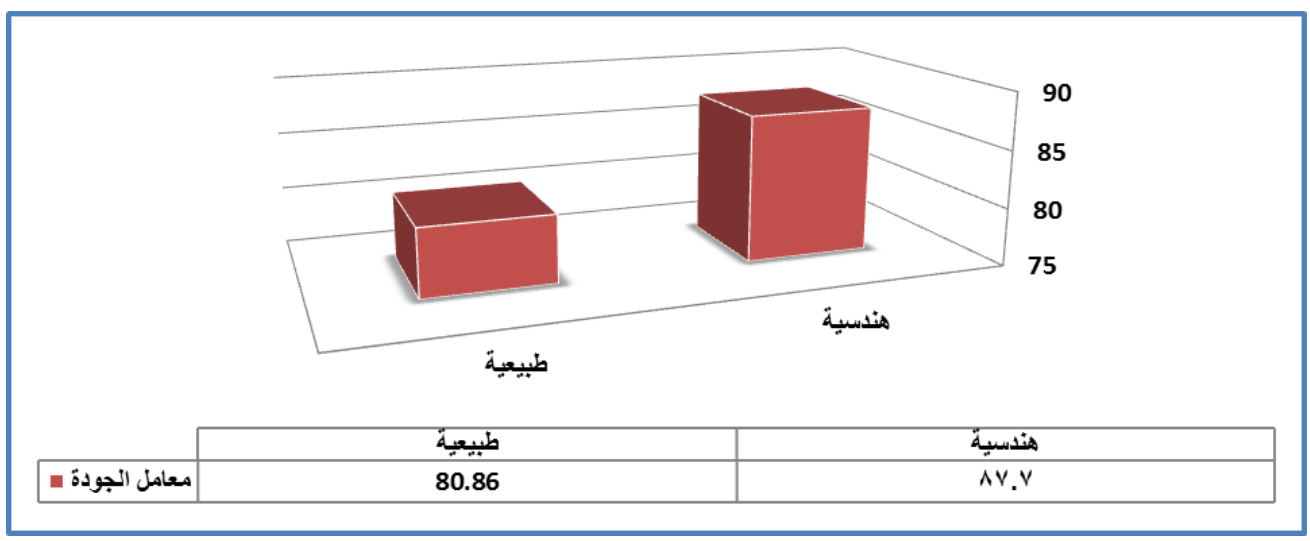

شكل (4) معامل الجودة لنوع الوحدة الزخرفية لعينات أقمشة الملابس الجورجيت في ضوء آراء

$$
\text { من الجدول (11) والثكل (3) والثكل (4) يتضح أن: }
$$

ل أفضل عينات أقشة الملابس الخفيفة (الجورجيت) وفقاً لنوع الوحدة الزخرفية

هي (العينة: رقم 7) بنوع غرزة التطريز (Satin stitch) ووحدة زخرفية

$$
\text { (هندسية)، وحجم الوحدة (3×3 سم) وعدد الوحدات المستخدمة (3 وحدات). }
$$

ل أقل عينات أقمشة الملابس الخفيفة (الجورجيت) وفقاً لنوع الوحدة الزخرفية هي

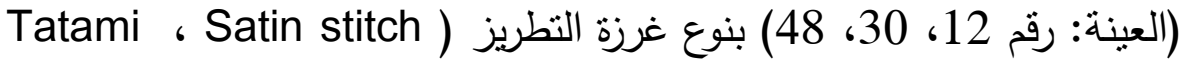
(Straight stitch ، stitch

$$
\text { الوحدة (5×5 سم) وعدد الوحدات المستخدمة (7 وحدات). }
$$

ل ترتيب نوع الوحدة الزخرفية لعينات أقششة الملابس الخفيفة (الجورجيت) وفقاً لآراء المتخصصين (هندسية) يليها (طبيعية) وتفسر الباحثة ذلك بأن الوحدة 
الهندية أعطت شكلاً جمالياً متفرداً ومظهرية عالية للعينات وهذا يتفق مع ماذكرته دراسة (محمد، 2021) بأن الوحدات الزخرفية الهندسية تستخدم فى فئه تزيين الأشرطة والإطارات والمنتجات المتعددة. وفى ضوء ما سبق يمكن قبول الفرض الثانى من فروض البحث والذي ينص على توجد فروق ذات دلالة إحصائية بين نوع الوحدة الزخرفية لعينات أقمشة الملابس

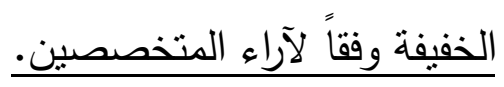
الفرض الثالث: توحد فروق ذات دلالة إحصائية بين حمب الوحدة الزخرفية لعينات

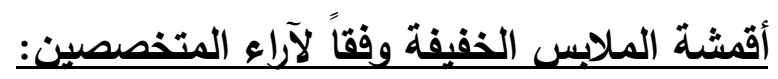
وللتحقق من صحة هذا الفرض ثم حساب تحليل التباين لمتوسط ثقييم عينات أقمشة الملابس الخفيفة (الجورجيت) وفقاً لحجم الوحدة الزخرفية في ضوء آراء المتخصصين

$$
\text { وجدول (12) يوضح ذللك: }
$$

جدول(12): تحليل التباين لمتوسط تقييم عينات أقشة الملابس الجورجيت وفقاً لحجم الوحدة

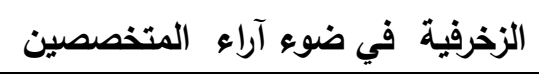

\begin{tabular}{|c|c|c|c|c|c|c|}
\hline الدلالة & قيمة ف & متوسط & الحرية & مجموع المربعات & مصدر التباين & \\
\hline \multirow{3}{*}{.000} & \multirow{3}{*}{40.966} & 13.402 & 53 & 710.327 & بين المجموعات & \multirow{3}{*}{ العينات } \\
\hline & & .327 & 108 & 35.333 & داخل المجموعات & \\
\hline & & & 161 & 745.660 & التباين الكلي & \\
\hline \multirow{3}{*}{.999} & \multirow{3}{*}{.001} & .006 & 2 & .012 & بين المجموعات & \multirow{3}{*}{ حجم الزحدة } \\
\hline & & 4.690 & 159 & 745.648 & داخل المجموعات & \\
\hline & & & 161 & 745.660 & التباين الكلي & \\
\hline
\end{tabular}

1. وجود فرق دال إحصائياً عند مستوي (0.01) بين عينات أقشة المالبس الخفيفة (الجورجيت) وفقاً لآراء المتخصصين حيث فيمة (ف) كانت دانت

$$
\text { (40.966) وهي قيمة دالة إحصائياً. }
$$

2. عدم وجود فرق دال إحصائياً بين حجم الوحدة الزخرفية لعينات أقمشة الملابس الخفيفة (الجورجيت) وفقاً لآراء المتخصصين حيث قيمة (ف) كانت (001.) 
وهي قيمة غير دالة إحصائياً، ويتفق ذلك مع نتائج الخواص الميكانيكية للعينات المطرزة تحت البحث الموضحة فى الجدولين (26،22)، وتفسر الباحثة ذلك بأن الأحجام المستخدمة للوحدة الزخرفية تناسبت مع الخامة الخفيفة ولم تؤدى لتخريم زائد فى الخامة كما ظهر جمال التطريز باستخدام

\section{هذه الأحجام للوحدة الزخرفية.}

والجدول التالي يوضح المتوسطات ومعامل الجودة لعينات أقشة الملابس الخفيفة (الجورجيت) وفقاً لآراء المتخصصين.

جدول(13): المتوسطات والانحراف المعيارى ومعامل الجودة لعينات أقمشة الملابس الجورجيت

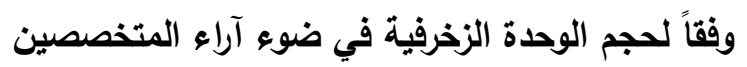

\begin{tabular}{|c|c|c|c|c|c|c|c|c|}
\hline التصميمات & الجودة & المعياري & المتوسط & علد الزخرفية فى المحات & الزحجمة الزحرة & الزحوة الزخدة & نوع غرزة & العينة \\
\hline 2 & 98.89 & 0.58 & 29.67 & 3 & \multirow{3}{*}{$5 \times 5$} & \multirow{9}{*}{. } & \multirow{18}{*}{ 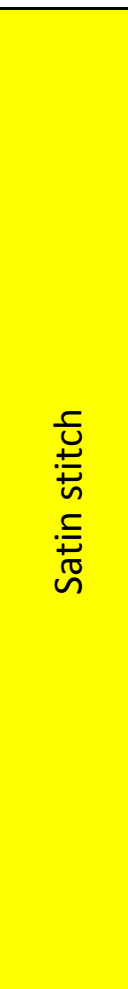 } & 1 \\
\hline 4 & 92.22 & 0.58 & 27.67 & 5 & & & & 2 \\
\hline 6 & 85.56 & 0.58 & 25.67 & 7 & & & & 3 \\
\hline 2 & 98.89 & 0.58 & 29.67 & 3 & \multirow{3}{*}{$4 \times 4$} & & & 4 \\
\hline 4 & 92.22 & 0.58 & 27.67 & 5 & & & & 5 \\
\hline 6 & 85.56 & 0.58 & 25.67 & 7 & & & & 6 \\
\hline 1 & 100.00 & 0.00 & 30.00 & 3 & \multirow{3}{*}{$3 \times 3$} & & & 7 \\
\hline 4 & 92.22 & 0.58 & 27.67 & 5 & & & & 8 \\
\hline 6 & 85.56 & 0.58 & 25.67 & 7 & & & & 9 \\
\hline 4 & 92.22 & 0.58 & 27.67 & 3 & \multirow{3}{*}{$5 \times 5$} & \multirow{9}{*}{ 寻: } & & 10 \\
\hline 6 & 85.56 & 0.58 & 25.67 & 5 & & & & 11 \\
\hline 8 & 78.89 & 0.58 & 23.67 & 7 & & & & 12 \\
\hline 4 & 92.22 & 0.58 & 27.67 & 3 & \multirow{3}{*}{$4 \times 4$} & & & 13 \\
\hline 6 & 85.56 & 0.58 & 25.67 & 5 & & & & 14 \\
\hline 8 & 78.89 & 0.58 & 23.67 & 7 & & & & 15 \\
\hline 4 & 92.22 & 0.58 & 27.67 & 3 & \multirow{3}{*}{$3 \times 3$} & & & 16 \\
\hline 6 & 85.56 & 0.58 & 25.67 & 5 & & & & 17 \\
\hline 8 & 78.89 & 0.58 & 23.67 & 7 & & & & 18 \\
\hline 3 & 95.56 & 0.58 & 28.67 & 3 & \multirow{3}{*}{$5 \times 5$} & \multirow{3}{*}{ 恿 } & \multirow{3}{*}{ 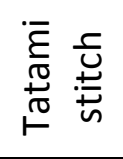 } & 19 \\
\hline 5 & 88.89 & 0.58 & 26.67 & 5 & & & & 20 \\
\hline 7 & 82.22 & 0.58 & 24.67 & 7 & & & & 21 \\
\hline
\end{tabular}


مجلة البحوث فى مجالات التربية النوعية

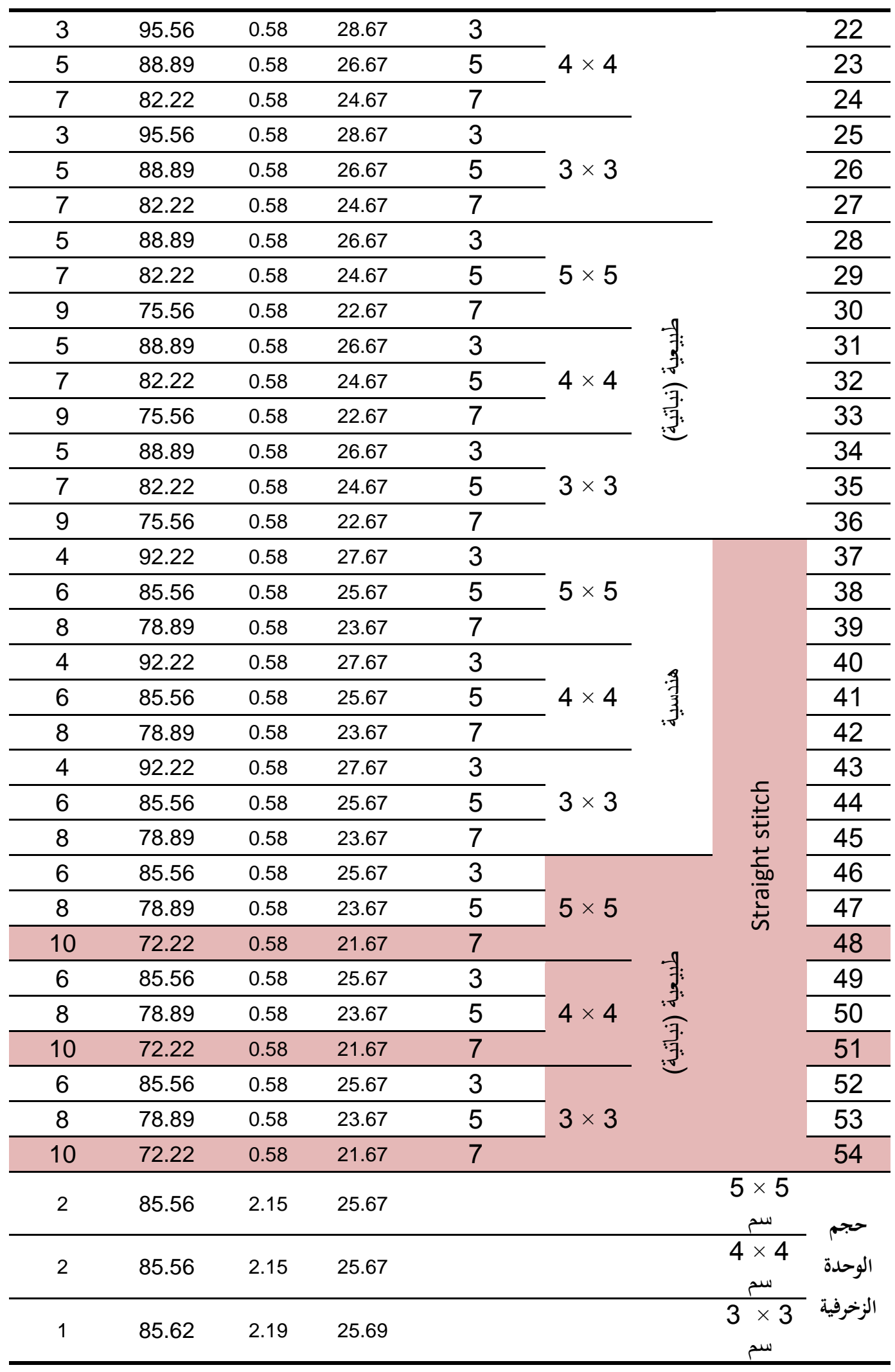




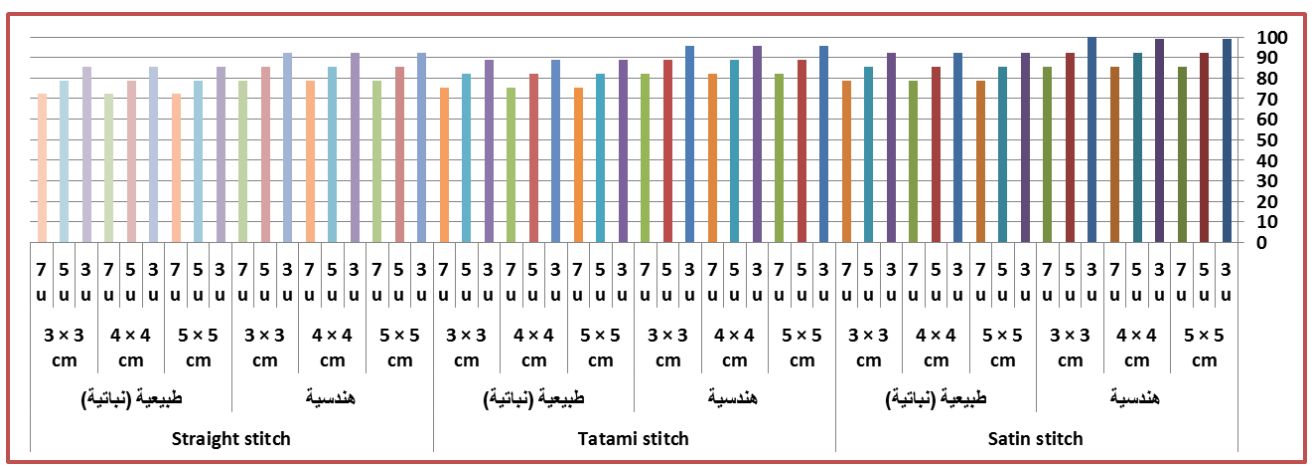

شكل (5) معامل الجودة لتقييم عينات أقمشة الملابس الجورجيت وفقاً لحجم الوحدة الزخرفية في ضوء آراء المتخصصين

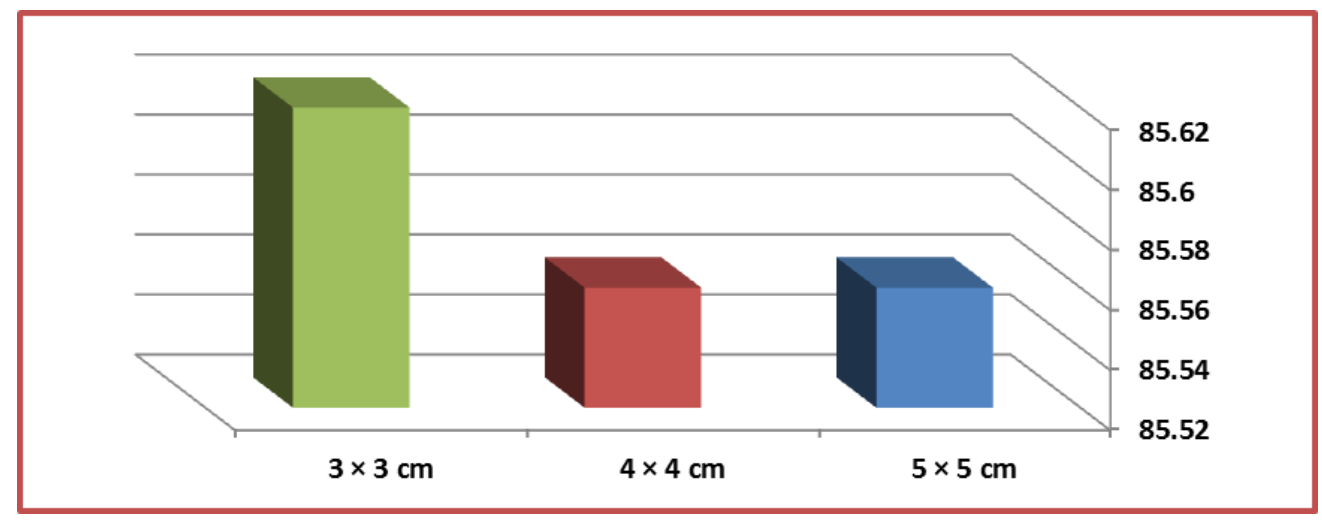

شكل (6) معامل الجودة لحجم الوحدة الزخرفية لعينات أقمشة الملابس الجورجيت في ضوء آراء

$$
\text { من الجدول (13) والثكل (5) والثكل (6) بتضح أن: المتضصين }
$$

ل أفضل عينات أقشة الملابس الخفيفة (الجورجيت) وفقاً لحجم الوحدة الزخرفية هي (العينة: رقم 7) بنوع غرزة التطريز (Satin stitch) ووحدة زخرفية (هندسية)، وحجم الوحدة (3×3 سم) وعدد الوحدات المستخدمة (3 وحدات). ل أقل عينات أقشة الملابس الخفيفة (الجورجيت) وفقاً لحجم الوحدة الزخرفية هي (العينة: رقم 48، 51، 54) بنوع غرزة التطريز (Straight stitch) علي

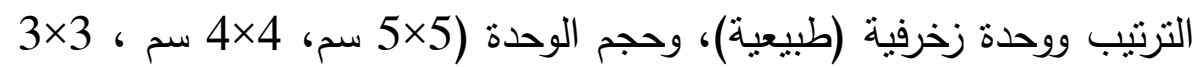

$$
\text { سم) علي الترتيب وعدد الوحدات المستخدمة (7 وحدات). }
$$


ل نزتيب حجم الوحدة الزخرفية لعينات أقمشة الملابس الخفيفة (الجورجيت) وفقاً

$$
\text { لآراء المتخصصين (3×3 سم، 4×4 سم بالتساوي مع 5×5 سم). }
$$

وفي ضوء ما سبق يمكن رفض الفرض الثالث من فروض البحث والذي ينص علي: توجد فروق ذات دلالة إحصائية بين حجم الوحدة الزخرفية لعينات أقشة الملابس الخفيفة وقبول الفرض فيما يخص الفروق بين العينات المطرزة وفقا لآراء المتخصصين.

الفرض الرايع: توحد فروق ذات دلائة إحصائية بين عدد الوحدات الزخرفية لعينات أقمشة الملابس الخففةة وفقاً لآراءع المتخصصين: وللتحقق من صحة هذا الفرض تم حساب تحليل التباين لمتوسط تقييم عينات أقمشة الملابس الخفيفة (الجورجيت) وفقاً لعدد الوحدات الزخرفية في ضوء آراء المتخصصين

$$
\text { وجدول (14) يوضح ذللك: }
$$

جدول(14): تحليل التباين لمتوسط تقييم عينات أقمشة الملابس الجورجيت وفقا لعدد الوحدات

\begin{tabular}{|c|c|c|c|c|c|c|}
\hline الدلالة & قيمة ف & المربعات & الحرجة & مجموع المربعات & مصدر التباين & \\
\hline \multirow{3}{*}{.000} & \multirow{3}{*}{2.402} & 10.009 & 53 & 530.500 & بين المجموعات & \multirow{3}{*}{ العينات } \\
\hline & & 4.167 & 108 & 450.000 & داخل المجموعات & \\
\hline & & & 161 & 980.500 & التباين الكلي & \\
\hline \multirow{3}{*}{.018} & \multirow{3}{*}{4.092} & 24.000 & 2 & 48.000 & بين المجموعات & عدد \\
\hline & & 5.865 & 159 & 932.500 & داخل المجموعات & الوحدات \\
\hline & & & 161 & 980.500 & التباين الكلي & الزخرفية \\
\hline
\end{tabular}
الزخرفية في ضوء آراء المتخصصين

1. وجود فرق دال إحصائياً عند مستوي (0.01) بين عينات أقشة الملابس الخفيفة (الجورجيت) وفقاً لآراء المتخصصين حيث قيمة (ف) كانت (2.402) وهي قيمة دالة إحصائياً. 
2. وجود فرق دال إحصائياً عند مستوي (0101) بين عدد الوحدات الزخرفية

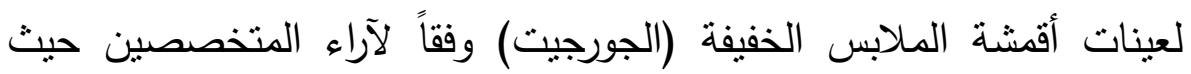

$$
\text { قيمة (ف) كانت (4.092) وهي قيمة دالة إحصائياً. }
$$

والجدول التالي يوضح المتوسطات ومعامل الجودة لعينات أقشة الملابس الخفيفة (الجورجيت) وفقاً لآراء المتخصصين.

جدول(15): المتوسطات والانحراف المعيارى ومعامل الجودة لعينات أقمشة الملابس الجورجيت

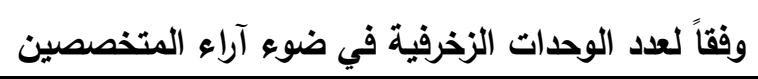

\begin{tabular}{|c|c|c|c|c|c|c|c|c|}
\hline التصميمات & الجودة & الانحراف & المتوسط & عدا الزخرفية فى الوحدات & الزحجة & الونوعة الزحرفة & نوع غرزة & العينة \\
\hline 4 & 94.44 & 1.53 & 28.33 & 3 & \multirow{3}{*}{$5 \times 5$} & \multirow{9}{*}{ 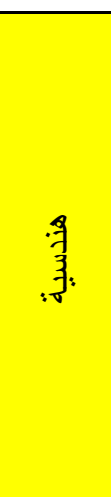 } & \multirow{18}{*}{ 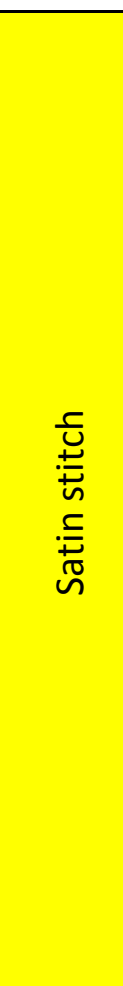 } & 1 \\
\hline 6 & 92.22 & 2.08 & 27.67 & 5 & & & & 2 \\
\hline 8 & 90.00 & 2.65 & 27.00 & 7 & & & & 3 \\
\hline 2 & 96.67 & 1.00 & 29.00 & 3 & \multirow{3}{*}{$4 \times 4$} & & & 4 \\
\hline 4 & 94.44 & 1.53 & 28.33 & 5 & & & & 5 \\
\hline 6 & 92.22 & 2.08 & 27.67 & 7 & & & & 6 \\
\hline 1 & 98.89 & 0.58 & 29.67 & 3 & \multirow{3}{*}{$3 \times 3$} & & & 7 \\
\hline 2 & 96.67 & 1.00 & 29.00 & 5 & & & & 8 \\
\hline 4 & 94.44 & 1.53 & 28.33 & 7 & & & & 9 \\
\hline 10 & 86.67 & 1.73 & 26.00 & 3 & \multirow{6}{*}{$4 \times 4$} & \multirow{9}{*}{ 承: } & & 10 \\
\hline 11 & 84.44 & 2.31 & 25.33 & 5 & & & & 11 \\
\hline 12 & 82.22 & 2.89 & 24.67 & 7 & & & & 12 \\
\hline 9 & 88.89 & 1.15 & 26.67 & 3 & & & & 13 \\
\hline 10 & 86.67 & 1.73 & 26.00 & 5 & & & & 14 \\
\hline 11 & 84.44 & 2.31 & 25.33 & 7 & & & & 15 \\
\hline 7 & 91.11 & 0.58 & 27.33 & 3 & \multirow{3}{*}{$3 \times 3$} & & & 16 \\
\hline 9 & 88.89 & 1.15 & 26.67 & 5 & & & & 17 \\
\hline 10 & 86.67 & 1.73 & 26.00 & 7 & & & & 18 \\
\hline 7 & 91.11 & 1.53 & 27.33 & 3 & \multirow{3}{*}{$5 \times 5$} & \multirow{6}{*}{ 罗 } & \multirow{6}{*}{ 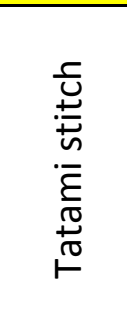 } & 19 \\
\hline 9 & 88.89 & 2.08 & 26.67 & 5 & & & & 20 \\
\hline 10 & 86.67 & 2.65 & 26.00 & 7 & & & & 21 \\
\hline 5 & 93.33 & 1.00 & 28.00 & 3 & \multirow{3}{*}{$4 \times 4$} & & & 22 \\
\hline 7 & 91.11 & 1.53 & 27.33 & 5 & & & & 23 \\
\hline 9 & 88.89 & 2.08 & 26.67 & 7 & & & & 24 \\
\hline
\end{tabular}


مجلة البحوث فى مجالات التربية النوعية

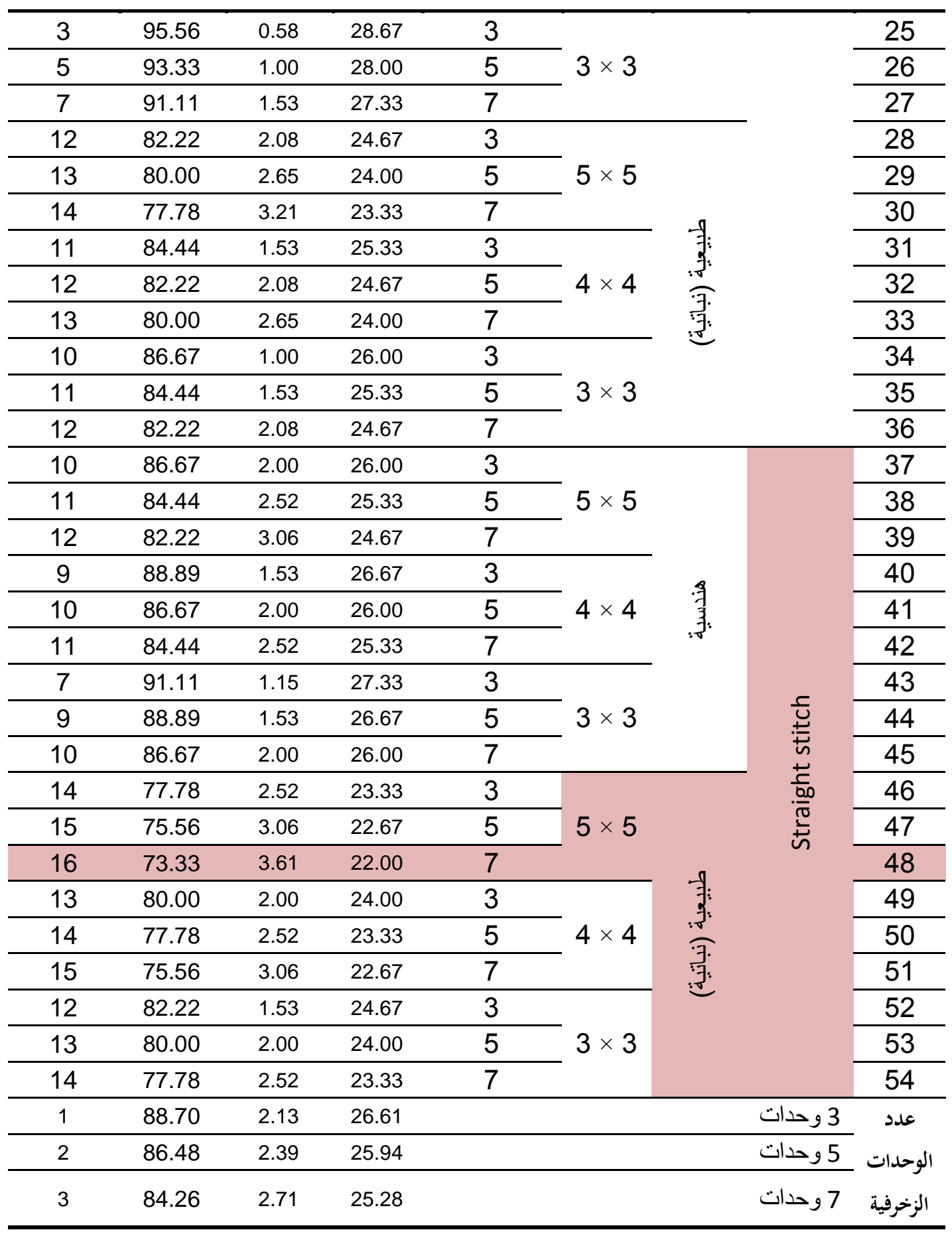




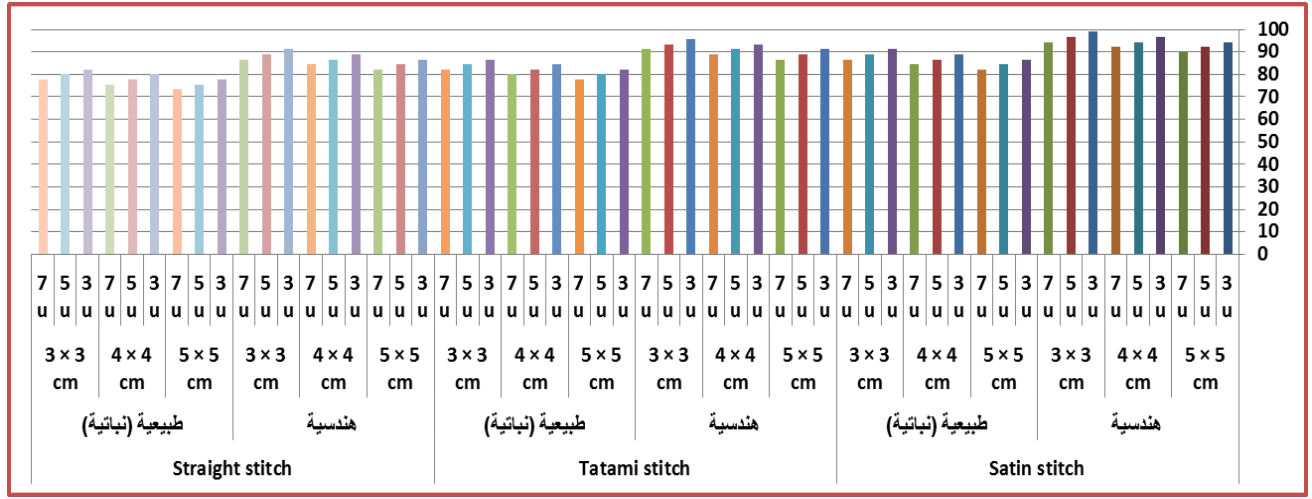

شكل (7) معامل الجودة لتقييم عينات أقشة الملابس الجورجيت وفقاً لعدد الوحدات الزخرفية في ضوء آراء المتخصصين

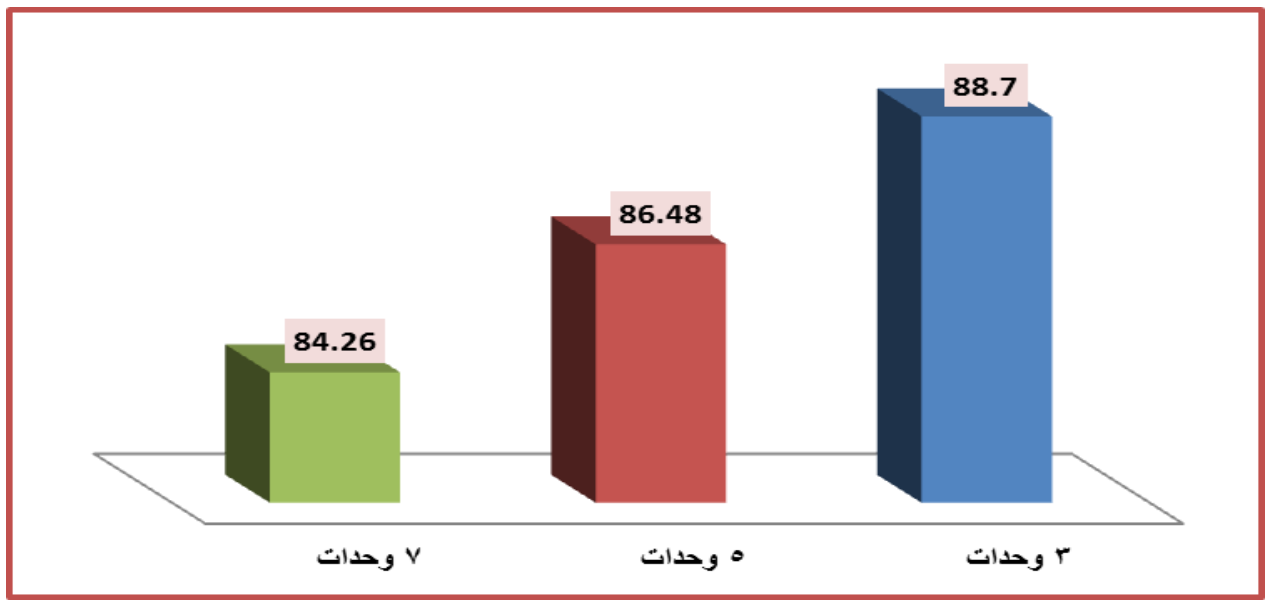

شكل (8) معامل الجودة لعدد الوحدات الزخرفية لعينات أقشة الملابس الجورجيت في ضوء آراء

$$
\text { من الجدول (15) والثكل (7) والثكل (8) يتضح أن: }
$$

ل أفضل عينات أقمشة الملابس الخفيفة (الجورجيت) وفقاً لعدد الوحدات الزخرفية هي (العينة: رقم 7) بنوع غرزة التطريز (Satin stitch) ووحدة زخرفية

$$
\text { (هندسية)، وحجم الوحدة (3×3 سم) وعدد الوحدات المستخدمة (3 وحدات). }
$$

ل أقل عينات أقشة الملابس الخفيفة (الجورجيت) وفقاً لعدد الوحدات الزخرفية هي (العينة: رقم 48) بنوع غرزة التطريز (Straight stitch) ووحدة زخرفية (طبيعية)، وحجم الوحدة (5×5 سم) وعدد الوحدات المستخدمة (7 وحدات). ل ترتيب عدد الوحدات الزخرفية لعينات أقششة الملابس الخفيفة (الجورجيت) وفقاً لآراء المتخصصين (3 وحدات، 5 وحدات، 7 وحدات) وتفسر الباحثة ذلك 
بأن عيوب مظهرية الأقمشة المطرزة قد نزجع إلى التصميم عن طريق تجمع أو تكتل الخيط فى أماكن اتصال التصميم بسبب قصور التصميم المتصل وهذا يتفق مع دراسة (Radostina,et,al.,2016)، وأكدته نتائج دراسة (سويلم و عطية، 2018) التى توصلت لوجود فروق ذات دلالة إحصائية بين العينات المنفذة فى نوع التصميم المستخدم فى التطريز لصالح التصميم المنفصل، ولهذا فكلما قل عدد الوحدات الزخرفية فى المساحة المطرزة كلما كان أفضل لتقليل فرصة الاتصال بين الوحدات. وفي ضوء ما سبق يمكن قبول الفرض الرابع من فروض البحث والذي ينص على: توجد فروق ذات دلالة إحصائية بين عدد الوحدات الزخرفية لعينات أقمشة الملابس الخفيفة وفقاً لآراء المتخصصين. الفرض الخامس: توجد فروق ذات دلالة إحصائية بين محاور التقييم (ككل) لعينات أقمشة الملابس الخففةة وفقاً لآراءع المتخصصين: وللتحقق من صحة هذا الفرض تم حساب تحليل التباين بين محاور التقييم (ككل) لعينات أقمشة الملابس الخفيفة (الجورجيت) في ضوء آراء المتخصصين وجدول (16) يوضح ذللك: جدول(16): تحليل التباين بين محاور التقييم (ككل) لعينات أقمشة الملابس الجورجيت في ضوء آراء المتخصصين

\begin{tabular}{|c|c|c|c|c|c|c|}
\hline الدلالة & قيمة ف & المتوسطات & درجة & مجموع المربعات & مصدر التباين & \\
\hline \multirow{3}{*}{.000} & \multirow{3}{*}{12.143} & 38.993 & 53 & 2066.615 & بين المجموعات & \multirow{3}{*}{ العينات } \\
\hline & & 3.211 & 648 & 2080.769 & داخل المجموعات & \\
\hline & & & 701 & 4147.385 & التباين الكلي & \\
\hline \multirow{3}{*}{.001} & \multirow{3}{*}{5.208} & 30.268 & 3 & 90.804 & بين المجموعات & \multirow{3}{*}{ المحاور } \\
\hline & & 5.812 & 698 & 4056.580 & داخل المجموعات & \\
\hline & & & 701 & 4147.385 & التباين الكلي & \\
\hline
\end{tabular}


1. وجود فرق دال إحصائياً عند مستوي (0101) بين عينات أقشة الملابس الخفيفة (الجورجيت) وفقاً لآراء المتخصصين حيث قيمة (ف) كانت (12.143) وهي قيمة دالة إحصائياً.

2. وجود فرق دال إحصائياً عند مستوي (0.01) بين محاور تقييم عينات أقمشة الملابس الخفيفة (الجورجيت) وفقاً لآراء المتخصصين حيث قيمة (ف) كانت

$$
\text { (5.208) وهي قيمة دالة إحصائياً. }
$$

والجدول التالي يوضح المتوسطات ومعامل الجودة لعينات أقشة الملابس الخفيفة (الجورجيت) وفقاً لآراء المتخصصين.

جدول(17): المتوسطات والانحراف المعيارى ومعامل الجودة لمحاور تقييم عينات أقمشة الملابس

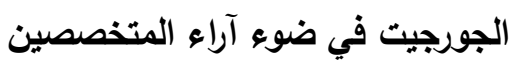

\begin{tabular}{|c|c|c|c|c|c|c|c|c|}
\hline التصميمات & الجودة & الانحراف & المتوسط & الزبد الوحلة فلى & الوحجد & الزوحة الزخرة & نوع غرزة & العينة \\
\hline 5 & 94.36 & 1.80 & 28.31 & 3 & \multirow{3}{*}{$5 \times 5$} & \multirow{9}{*}{ 争 } & \multirow{18}{*}{ 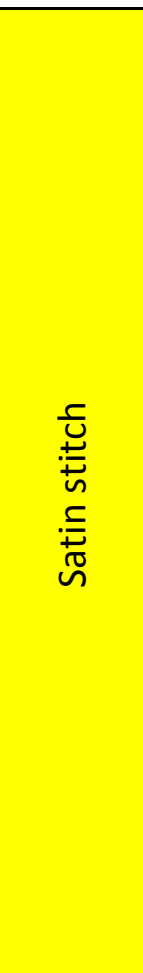 } & 1 \\
\hline 12 & 90.77 & 2.09 & 27.23 & 5 & & & & 2 \\
\hline 22 & 86.92 & 2.56 & 26.08 & 7 & & & & 3 \\
\hline 2 & 96.67 & 1.00 & 29.00 & 3 & \multirow{3}{*}{$4 \times 4$} & & & 4 \\
\hline 6 & 93.08 & 1.38 & 27.92 & 5 & & & & 5 \\
\hline 16 & 88.97 & 2.10 & 26.69 & 7 & & & & 6 \\
\hline 1 & 99.74 & 0.28 & 29.92 & 3 & \multirow{3}{*}{$3 \times 3$} & & & 7 \\
\hline 3 & 95.64 & 0.95 & 28.69 & 5 & & & & 8 \\
\hline 9 & 91.79 & 1.71 & 27.54 & 7 & & & & 9 \\
\hline 18 & 88.46 & 2.18 & 26.54 & 3 & \multirow{3}{*}{$5 \times 5$} & \multirow{9}{*}{ 承: } & & 10 \\
\hline 27 & 84.87 & 2.54 & 25.46 & 5 & & & & 11 \\
\hline 35 & 81.03 & 3.01 & 24.31 & 7 & & & & 12 \\
\hline 12 & 90.77 & 1.42 & 27.23 & 3 & \multirow{3}{*}{$4 \times 4$} & & & 13 \\
\hline 21 & 87.18 & 1.86 & 26.15 & 5 & & & & 14 \\
\hline 30 & 83.08 & 2.53 & 24.92 & 7 & & & & 15 \\
\hline 7 & 93.08 & 0.86 & 27.92 & 3 & \multirow{3}{*}{$3 \times 3$} & & & 16 \\
\hline 14 & 89.49 & 1.41 & 26.85 & 5 & & & & 17 \\
\hline 25 & 85.38 & 2.14 & 25.62 & 7 & & & & 18 \\
\hline 13 & 90.51 & 1.46 & 27.15 & 3 & \multirow{2}{*}{$5 \times 5$} & 沀 & \multirow{2}{*}{ 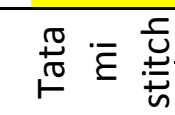 } & 19 \\
\hline 23 & 86.67 & 1.78 & 26.00 & 5 & & 承: & & 20 \\
\hline
\end{tabular}


مجلة البحوث فى مجالات التربية النوعية

\begin{tabular}{|c|c|c|c|c|c|c|c|c|}
\hline 30 & 83.08 & 2.14 & 24.92 & 7 & & & & 21 \\
\hline 8 & 92.82 & 0.90 & 27.85 & 3 & \multirow{3}{*}{$4 \times 4$} & & & 22 \\
\hline 15 & 89.23 & 1.09 & 26.77 & 5 & & & & 23 \\
\hline 26 & 85.13 & 1.76 & 25.54 & 7 & & & & 24 \\
\hline 4 & 95.13 & 0.97 & 28.54 & 3 & \multirow{3}{*}{$3 \times 3$} & & & 25 \\
\hline 10 & 91.54 & 1.05 & 27.46 & 5 & & & & 26 \\
\hline 19 & 87.69 & 1.65 & 26.31 & 7 & & & & 27 \\
\hline 28 & 84.36 & 1.84 & 25.31 & 3 & \multirow{3}{*}{$5 \times 5$} & \multirow{9}{*}{ 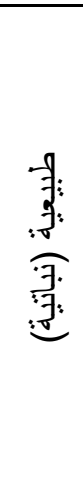 } & & 28 \\
\hline 36 & 80.77 & 2.13 & 24.23 & 5 & & & & 29 \\
\hline 42 & 76.92 & 2.60 & 23.08 & 7 & & & & 30 \\
\hline 23 & 86.67 & 1.22 & 26.00 & 3 & \multirow{3}{*}{$4 \times 4$} & & & 31 \\
\hline 30 & 83.08 & 1.55 & 24.92 & 5 & & & & 32 \\
\hline 40 & 78.97 & 2.18 & 23.69 & 7 & & & & 33 \\
\hline 16 & 88.97 & 1.03 & 26.69 & 3 & \multirow{3}{*}{$3 \times 3$} & & & 34 \\
\hline 25 & 85.38 & 1.33 & 25.62 & 5 & & & & 35 \\
\hline 34 & 81.28 & 1.94 & 24.38 & 7 & & & & 36 \\
\hline 24 & 86.41 & 1.71 & 25.92 & 3 & \multirow{3}{*}{$5 \times 5$} & \multirow{9}{*}{ 晖 } & \multirow{18}{*}{ 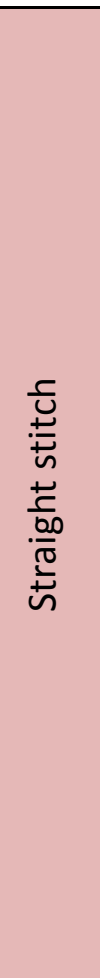 } & 37 \\
\hline 32 & 82.56 & 1.79 & 24.77 & 5 & & & & 38 \\
\hline 38 & 79.23 & 2.05 & 23.77 & 7 & & & & 39 \\
\hline 17 & 88.72 & 1.56 & 26.62 & 3 & \multirow{3}{*}{$4 \times 4$} & & & 40 \\
\hline 26 & 85.13 & 1.51 & 25.54 & 5 & & & & 41 \\
\hline 34 & 81.28 & 1.80 & 24.38 & 7 & & & & 42 \\
\hline 11 & 91.03 & 1.84 & 27.31 & 3 & \multirow{3}{*}{$3 \times 3$} & & & 43 \\
\hline 20 & 87.44 & 1.74 & 26.23 & 5 & & & & 44 \\
\hline 29 & 83.85 & 1.95 & 25.15 & 7 & & & & 45 \\
\hline 37 & 80.51 & 1.77 & 24.15 & 3 & \multirow{3}{*}{$5 \times 5$} & \multirow{9}{*}{ 寻: } & & 46 \\
\hline 43 & 76.92 & 1.93 & 23.08 & 5 & & & & 47 \\
\hline 45 & 73.33 & 2.35 & 22.00 & 7 & & & & 48 \\
\hline 31 & 82.82 & 1.46 & 24.85 & 3 & \multirow{3}{*}{$4 \times 4$} & & & 49 \\
\hline 39 & 79.23 & 1.59 & 23.77 & 5 & & & & 50 \\
\hline 44 & 75.38 & 2.02 & 22.62 & 7 & & & & 51 \\
\hline 26 & 85.13 & 1.61 & 25.54 & 3 & \multirow{3}{*}{$3 \times 3$} & & & 52 \\
\hline 33 & 81.54 & 1.66 & 24.46 & 5 & & & & 53 \\
\hline 41 & 77.69 & 1.97 & 23.31 & 7 & & & & 54 \\
\hline 1 & 87.47 & 2.58 & 26.24 & & \multicolumn{3}{|c|}{ نوع غرزة التطريز الآلي } & \\
\hline 4 & 84.28 & 2.36 & 25.28 & & \multicolumn{3}{|c|}{ حجم الوحدة الزخرفية } & المحاو \\
\hline 3 & 85.58 & 2.15 & 25.67 & & \multicolumn{3}{|c|}{ عدد الوحدات الزخرفية } & J \\
\hline 2 & 86.48 & 2.47 & 25.94 & & \multicolumn{3}{|c|}{ نوع الوحدة الزخرفية المستخدمة } & \\
\hline
\end{tabular}




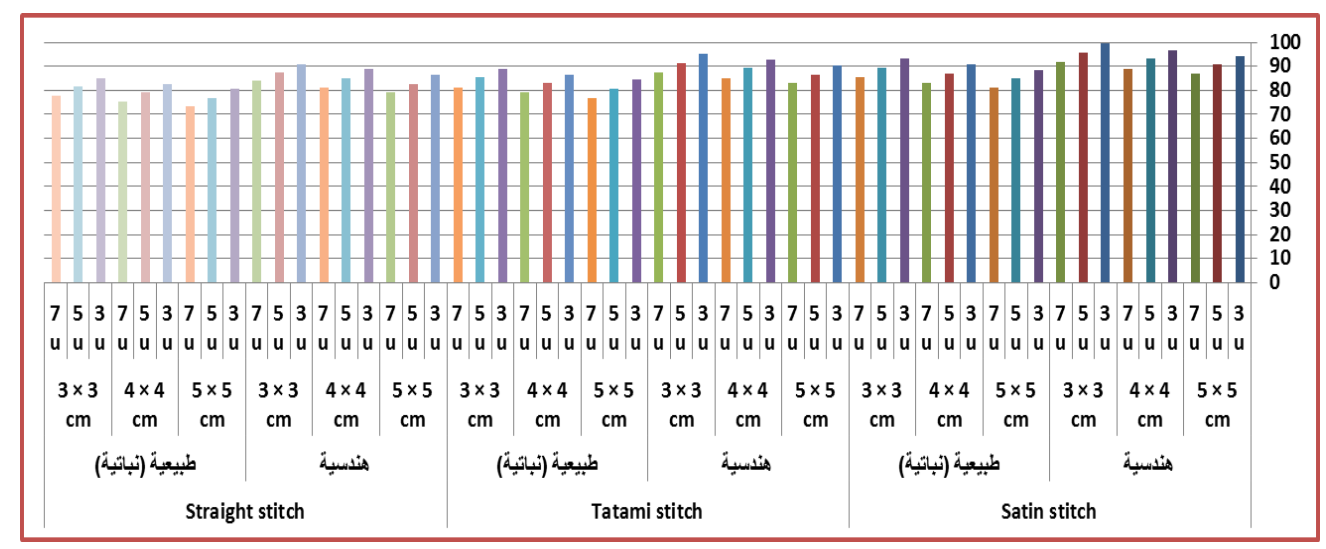

شكل (9) معامل الجودة لتقييم عينات أقمشة الملابس الجورجيت وفقاً لمحاور التقييم (ككل) في ضوء آراء المتخصصين

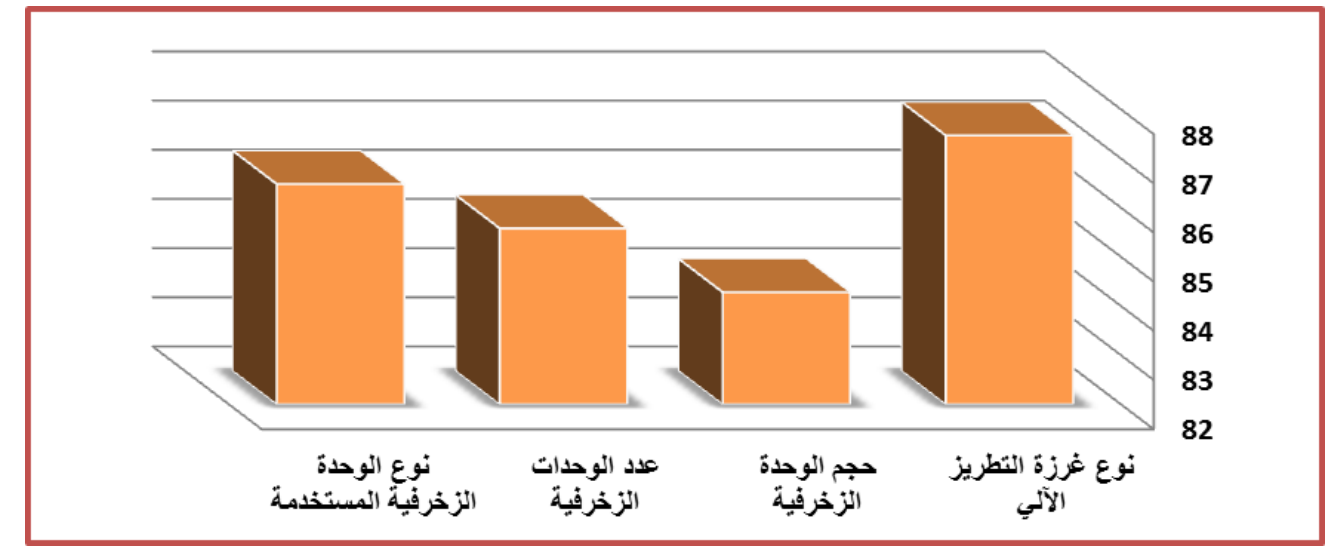

شكل (10) معامل الجودة لمحاور التقييم (ككل) لعينات أقمشة الملابس الجورجيت في ضوء آراء

$$
\text { من الجدول (17) والثكل (9) والثكل (10) يتضح أن: }
$$

ح أفضل عينات أقششة الملابس الخفيفة (الجورجيت) وفقاً لمحاور التقييم (ككل)

هي (العينة: رقم 7) بنوع غرزة التطريز (Satin stitch) ووحدة زخرفية (هندسية)، وحجم الوحدة (3×3 سم) وعدد الوحدات المستخدمة (3 وحدات).

ويمكن للباحثة تفسير ذلك بأن هذه العينة جمعت أفضل تقييم (نوع غرزة أفرة تطريز آلى، نوع للوحدة الزخرفية، حجم للوحدة الزخرفية، عدد للوحدات 
الزخرفية فى المساحة المطرزة) فأدى ذلك لأن تكون الأفضل وفقاً لآراء المتخصصين.

ل أقل عينات أقشة الملابس الخفيفة (الجورجيت) وفقاً لمحاور التقييم (ككل) هي (العينة: رقم 48) بنوع غرزة التطريز (Straight stitch) ووحدة زخرفية (طبيعية)، وحجم الوحدة (5×5 سم) وعدد الوحدات المستخدمة (7 وحدات). ويمكن للباحثة تفسير ذلك بأن هذه العينة جمعت أقل تقييم (نوع غرزة تطريز

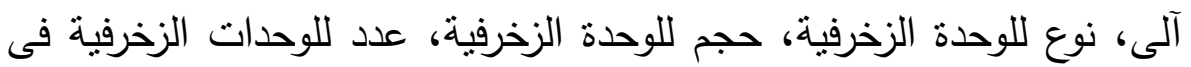

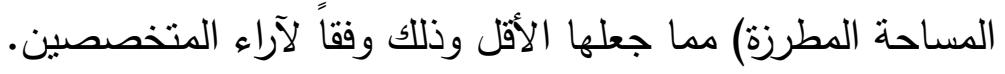
ل ترتيب محاور التقييم لعينات أقمشة الملابس الخفيفة (الجورجيت) وفقاً لآراء المتخصصين (نوع غرزة النطريز الآلي، نوع الوحدة الزخرفية المستخدمة، عدد

$$
\text { الوحدات الزخرفية فى المساحة المطرزة، حجم الوحدة الزخرفية). }
$$

وفي ضوء ما سبق يمكن قبول الفرض الخامس من فروض البحث والذي ينص على: توجد فروق ذات دلالة إحصائية بين محاور التقييم (ككل) لعينات أقمشة الملابس الخفيفة وفقاً لآراء المتخصصين.

ثانياً: نتائج استبيان تقييم العينات المطرزة لأقمشة الملابس الخفيفة وفقاً لآراء

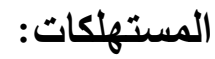

\section{الفرض السادس: توجد فروق ذات دلالة إحصائية بين بنود التقيم لعينات أقشية}

\section{الملابس الخفيفة وفقاً لآراء المستهلكات:}

وللتحقق من صحة هذا الفرض تم حساب تحليل التباين بين بنود التقييم لعينات أقششة الملابس الخفيفة (الجورجيت) في ضوء آراء المستهكات وجدول (18) يوضح ذللك: جدول (18): تحليل التباين بين بنود التقييم لعينات أقشة الملابس الجورجيت في ضوء آراء المسترهكاث

\begin{tabular}{|c|c|c|c|c|c|c|}
\hline الدلالة & قيمة ف & المتوسطات & درجة & مجموع المربعات & مصدر التباين & تصنيف \\
\hline \multirow{3}{*}{.000} & \multirow{3}{*}{6.845} & 34.428 & 53 & 1824.667 & بين المجموعات & \multirow{3}{*}{ (ككل) } \\
\hline & & 5.030 & 378 & 1901.250 & داخل المجموعات & \\
\hline & & & 431 & 3725.917 & التباين الكلي & \\
\hline
\end{tabular}


مجلة البحوث فى مجالات التربية النوعية

\begin{tabular}{|c|c|c|c|c|c|c|}
\hline \multirow{3}{*}{.000} & \multirow{3}{*}{43.663} & 315.083 & 2 & 630.167 & بين المجموعات & \multirow{3}{*}{ التوع غرزة } \\
\hline & & 7.216 & 429 & 3095.750 & داخل المجموعات & \\
\hline & & & 431 & 3725.917 & التباين الكلي & \\
\hline \multirow{3}{*}{.000} & \multirow{3}{*}{40.446} & 320.333 & 1 & 320.333 & بين المجموعات & نوع الوحدة \\
\hline & & 7.920 & 430 & 3405.583 & داخل المجموعات & الزخرفية \\
\hline & & & 431 & 3725.917 & التباين الكلي & المستخدمة \\
\hline \multirow{3}{*}{.000} & \multirow{3}{*}{28.365} & 217.583 & 2 & 435.167 & بين المجموعات & حجم \\
\hline & & 7.671 & 429 & 3290.750 & داخل المجموعات & الوحدة \\
\hline & & & 431 & 3725.917 & التباين الكلي & الزخرفية \\
\hline \multirow{3}{*}{.000} & \multirow{3}{*}{28.365} & 217.583 & 2 & 435.167 & بين المجموعات & 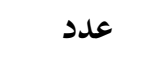 \\
\hline & & 7.671 & 429 & 3290.750 & داخل المجموعات & الوحدات \\
\hline & & & 431 & 3725.917 & التباين الكلي & الزخرفية \\
\hline
\end{tabular}

1. وجود فرق دال إحصائياً عند مستوي (0.01) بين عينات أقشة الملابس الخفيفة (الجورجيت) وفقاً لآراء المستهكات حيث قيمة (ف) كانت (6.845) وهي قيمة دالة إحصائياً.

2. وجود فرق دال إحصائياً عند مستوي (0101) بين نوع غرزة التطريز الآلي لعينات أقششة الملابس الخفيفة (الجورجيت) وفقاً لآراء المستهلكات حيث قيمة

$$
\text { (ف) كانت (43.663) وهي قيمة دالة إحصائياً. }
$$

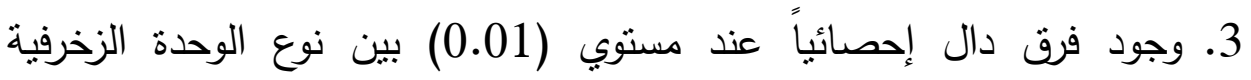
المستخدمة لعينات أقمشة الملابس الخفيفة (الجورجيت) وفقاً لآراء المستهات الكات حيث قيمة (ف) كانت (40.446) وهي قيمة دالة إحصائياً. 4. وجود فرق دال إحصائياً عند مستوي (0.01) بين حجم الوحدة الزخرفية لعينات أقمشة الملابس الخفيفة (الجورجيت) وفقاً لآراء المستهلكات حيث قيمة (ف) كانت (28.365) وهي قيمة دالة إحصائياً. 
5. وجود فرق دال إحصائياً عند مستوي (0.01) بين عدد الوحدات الزخرفية

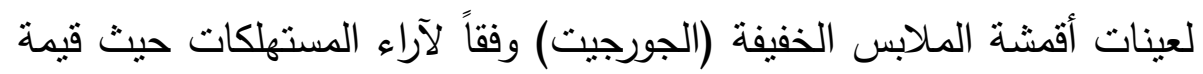

$$
\text { (ف) كانت (28.365) وهي قيمة دالة إحصائياً. }
$$

والجدول التالي يوضح المتوسطات ومعامل الجودة لعينات أقشة الملابس الخفيفة (الجورجيت) وفقاً لآراء المستهلكات.

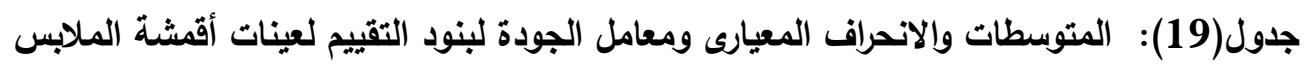
الجورجيت في ضوء آراء المستهلكات الجردات

\begin{tabular}{|c|c|c|c|c|c|c|c|c|}
\hline التصميمات & الجودة & اللانحراف & المتوسط & علدا الزخرفية فى المدات & الوحجدة الوخدية & الونوة & نوع غرزة التطريز & العينة \\
\hline 16 & 90.63 & 3.20 & 54.38 & 3 & \multirow{3}{*}{$5 \times 5$} & \multirow{9}{*}{ : } & \multirow{18}{*}{ 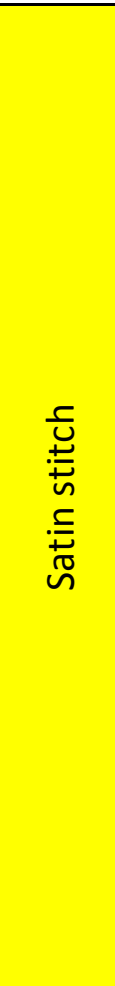 } & 1 \\
\hline 11 & 92.71 & 2.62 & 55.63 & 5 & & & & 2 \\
\hline 20 & 88.54 & 3.91 & 53.13 & 7 & & & & 3 \\
\hline 11 & 92.71 & 2.26 & 55.63 & 3 & \multirow{3}{*}{$4 \times 4$} & & & 4 \\
\hline 7 & 94.79 & 1.64 & 56.88 & 5 & & & & 5 \\
\hline 16 & 90.63 & 3.02 & 54.38 & 7 & & & & 6 \\
\hline 7 & 94.79 & 1.46 & 56.88 & 3 & \multirow{3}{*}{$3 \times 3$} & & & 7 \\
\hline 4 & 96.88 & 0.83 & 58.13 & 5 & & & & 8 \\
\hline 11 & 92.71 & 2.26 & 55.63 & 7 & & & & 9 \\
\hline 9 & 93.54 & 2.75 & 56.13 & 3 & \multirow{3}{*}{$5 \times 5$} & \multirow{9}{*}{ 寻: } & & 10 \\
\hline 5 & 95.63 & 2.20 & 57.38 & 5 & & & & 11 \\
\hline 14 & 91.46 & 3.44 & 54.88 & 7 & & & & 12 \\
\hline 5 & 95.63 & 1.77 & 57.38 & 3 & \multirow{3}{*}{$4 \times 4$} & & & 13 \\
\hline 2 & 97.71 & 1.19 & 58.63 & 5 & & & & 14 \\
\hline 9 & 93.54 & 2.53 & 56.13 & 7 & & & & 15 \\
\hline 2 & 97.71 & 0.92 & 58.63 & 3 & \multirow{3}{*}{$3 \times 3$} & & & 16 \\
\hline 1 & 99.79 & 0.35 & 59.88 & 5 & & & & 17 \\
\hline 5 & 95.63 & 1.77 & 57.38 & 7 & & & & 18 \\
\hline 21 & 88.13 & 2.90 & 52.88 & 3 & \multirow{3}{*}{$5 \times 5$} & \multirow{6}{*}{ : } & \multirow{6}{*}{ 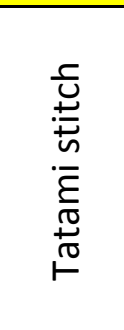 } & 19 \\
\hline 17 & 90.21 & 2.42 & 54.13 & 5 & & & & 20 \\
\hline 24 & 86.04 & 3.54 & 51.63 & 7 & & & & 21 \\
\hline 17 & 90.21 & 2.03 & 54.13 & 3 & \multirow{3}{*}{$4 \times 4$} & & & 22 \\
\hline 12 & 92.29 & 1.60 & 55.38 & 5 & & & & 23 \\
\hline 21 & 88.13 & 2.70 & 52.88 & 7 & & & & 24 \\
\hline
\end{tabular}


مجلة البحوث فى مجالات التربية النوعية

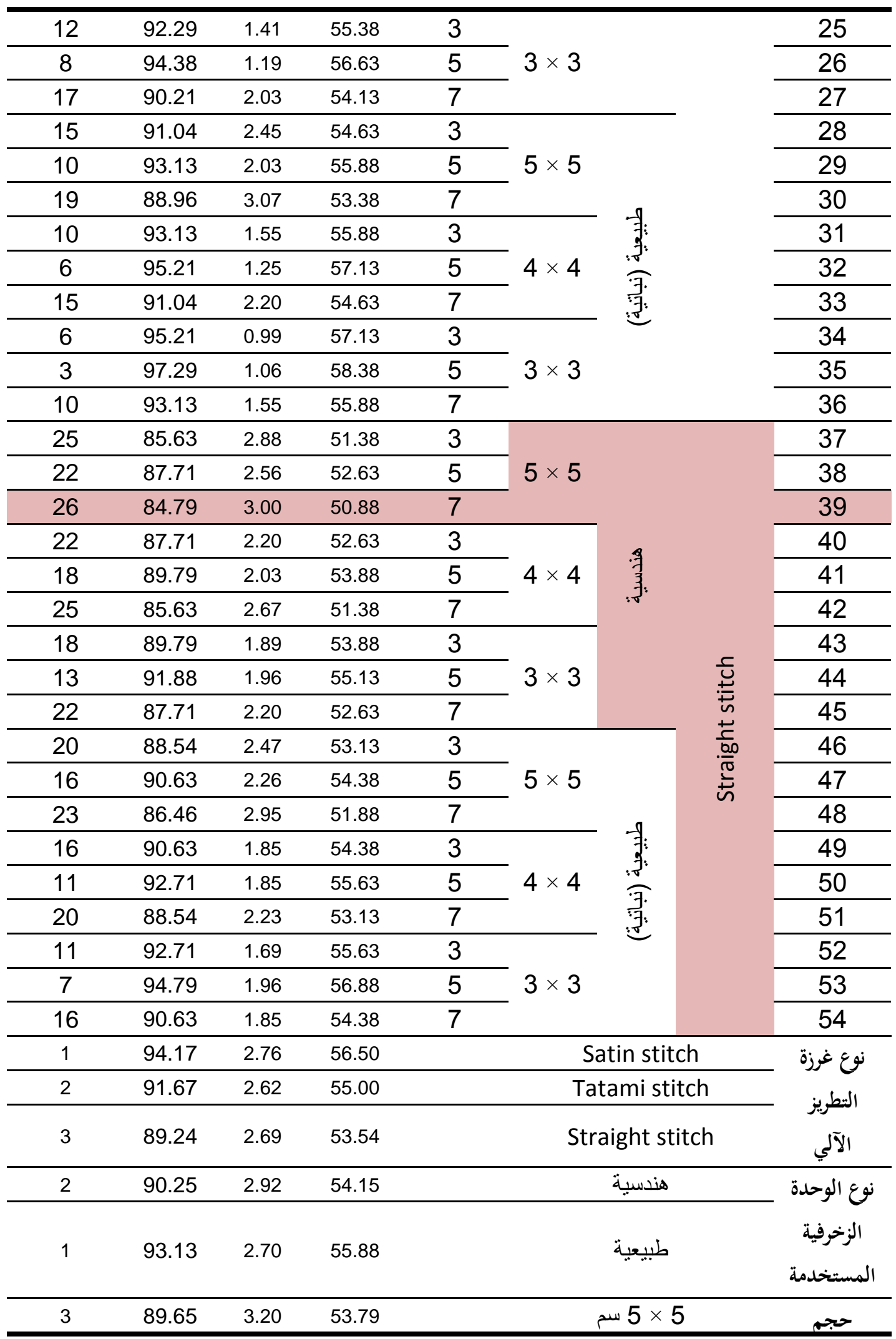


مجلة البحوث فى مجالات التربية النوعية

\begin{tabular}{|c|c|c|c|c|c|}
\hline 2 & 91.67 & 2.68 & 55.00 & 4 × 4 سم & الوحدة \\
\hline 1 & 93.75 & 2.37 & 56.25 & 3 × 3 سم & الزخرفية \\
\hline 2 & 91.67 & 2.71 & 55.00 & 3 وحدات & عدد \\
\hline 1 & 93.75 & 2.50 & 56.25 & 5 وحدات & الوحدات \\
\hline 3 & 89.65 & 3.07 & 53.79 & 7 وحدات & الزخرفية \\
\hline
\end{tabular}

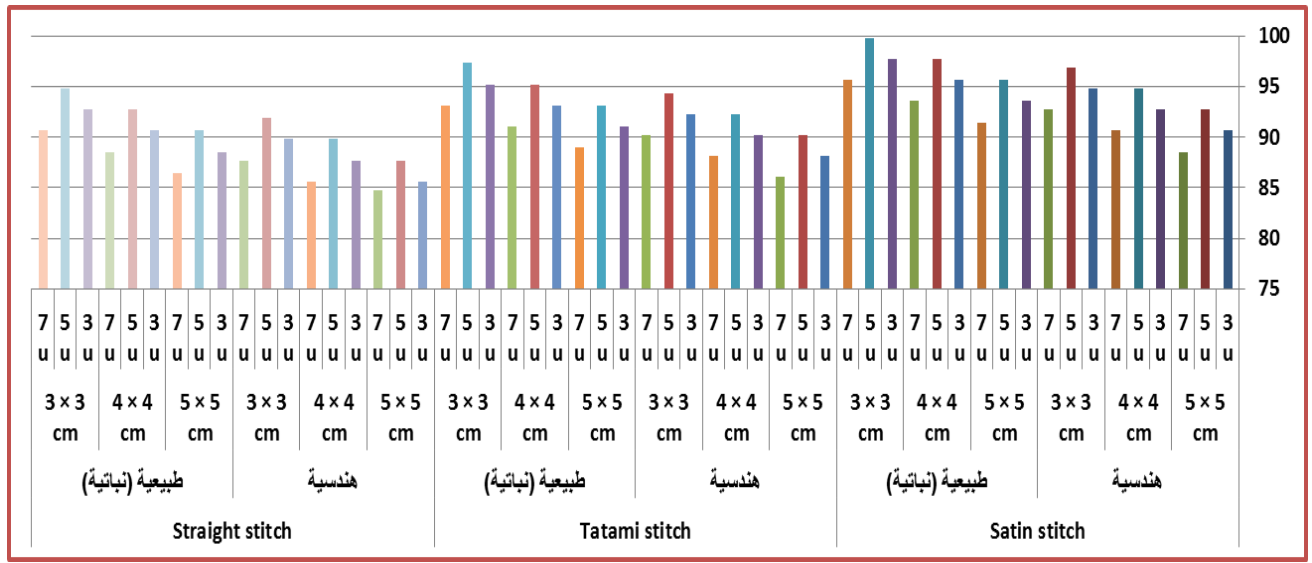

شكل (11) معامل الجودة لتقييم عينات أقشة الملابس الجورجيت وفقاً لبنود التقييم في ضوء آراء المستهات

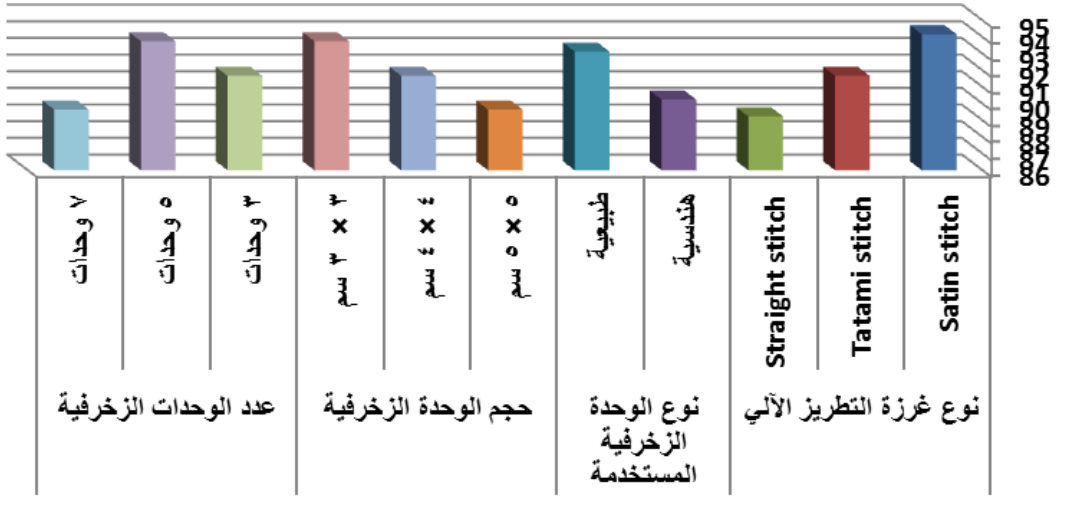

شكل (12) معامل الجودة لبنود التقييم لعينات أقمشة الملابس الجورجيت في ضوء آراء المستهلكات

من الجدول (19) والثكل (11) والثكل (12) يتضح أن:

ل أفضل عينات أقمشة الملابس الخفيفة (الجورجيت) وفقاً لبنود التقييم هي (العينة: رقم 17) بنوع غرزة النطريز (Satin stitch) ووحدة زخرفية 
(طبيعية)، وحجم الوحدة (3×3 سم) وعدد الوحدات المستخدمة (5 وحدات). ويمكن للباحثة تفسير ذلك بأن هذه العينة جمعت أفضل تقييم (نوع غرزة، نوع وحدة، حجم للوحدة، عدد للوحدات الزخرفية) فأدى ذلك لأن تكون الأفضل وفقاً لآراء المستهلكات.

ل أقل عينات أقمشة الملابس الخفيفة (الجورجيت) وفقاً لبنود التقييم هي (العينة: رقم 39) بنوع غرزة التطريز (Straight stitch) ووحدة زخرفية (هندسية)، وحجم الوحدة (5×5 سم) وعدد الوحدات المستخدمة (7 وحدات). ويمكن للباحثة تفسير ذلك بأن هذه العينة جمعت أقل تقييم (نوع غرزة، نوع وحدة، حجم للوحدة، عدد للوحدات الزخرفية) مما جعلها الأقل وذلك وفقاً لآراء المستهلكات. ل ترنيب بنود التقييم وفقاً لنوع غرزة التطريز الآلي لعينات أقششة الملابس الخفيفة (الجورجيت) وفقاً لآراء المستهلكات (Stitchi stitch، Satin stitami Satin وهذا يتفق مع رأى المتخصصين حيث تعطى (Straight stitch ، stitch

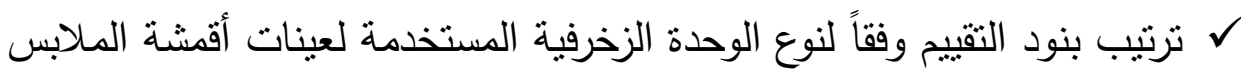
الخفيفة (الجورجيت) وفقاً لآراء المستهلكات (طبيعية، هندسية) ويمكن للباحثة تفسير ذلك بأن الوحدة الطبيعية المستخدمة على شكل زهرة وهى شائعة الاستخدام ومناسبة لفساتين السيدات والفتيات المسائية. ل ترتيب بنود التقييم وفقاً لحجم الوحدة الزخرفية لعينات أقششة الملابس الخفيفة (الجورجيت) وفقاً لآراء المستهكات (3×3سم، 4×4 سم، 5×5 سم) ويمكن للباحثة تفسير ذلك بأن الحجم الصغير يعطى تطريز ناعم ولا يجهد الخامة مع الاحتفاظ بوضوح شكل الغرزة. ل ترتيب بنود التقبيم وفقاً لعدد الوحدة الزخرفية لعينات أقششة الملابس الخفيفة (الجورجيت) وفقاً لآراء المستهكات (5 وحدات، 3 وحدات، 7 وحدات) ويمكن للباحثة تفسير ذلك بعدم الرغبة فى نرك مساحات كبيرة بدون تطريز . 
وفى ضوء ما سبق يمكن قبول الفرض السادس من فروض البحث والذي ينص على: توجد فروق ذات دلالة إحصائية بين بنود التقييم لعينات أقمشة الملابس الخفيفة وفقاً لآراء المستهلكات. ثالثا: مناقثة العلاقة الارتباطية بين نتائج البحث في ضوء آراء المتخصصين، وآراء

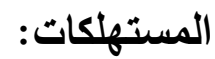

الفرض السابع: توحد علاقة ارتباطبة بين ترتيب المتخصصين وترتيب المستهلكات لعينات أقمشة الملابس الخفيفة المطرزة: قامت الباحثة بحساب معامل ارتباط الرتب لسبيرمان بين ترتيب المتخصصين والمستهكات لعينات أقششة الملابس الخفيفة (الجورجيت) المطرزة كما هو موضح

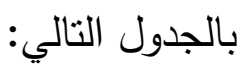

جدول (20) معامل ارتباط الرتب لسبيرمان لمعرفة العلاقة الارتباطية بين ترتيب المتخصصين والمستهكات لعينات أقشة الملابس الجورجيت المطرزة

\begin{tabular}{|c|c|c|c|c|c|c|c|}
\hline $\begin{array}{l}\text { الارتباط } \\
\text { معامل }\end{array}$ & المستهلكات & المتخصصين & عدد الزخرفية فى المسات & الوحجدة & الوحدة & نوع غرزة التطريز & العينة \\
\hline \multirow{16}{*}{ 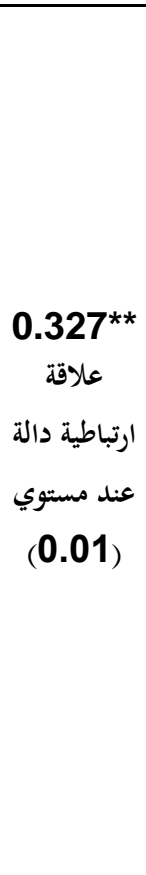 } & 16 & 5 & 3 & \multirow{3}{*}{$5 \times 5$} & \multirow{9}{*}{ 畓 } & \multirow{16}{*}{ 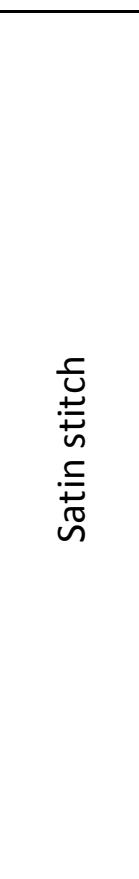 } & 1 \\
\hline & 11 & 12 & 5 & & & & 2 \\
\hline & 20 & 22 & 7 & & & & 3 \\
\hline & 11 & 2 & 3 & \multirow{3}{*}{$4 \times 4$} & & & 4 \\
\hline & 7 & 6 & 5 & & & & 5 \\
\hline & 16 & 16 & 7 & & & & 6 \\
\hline & 7 & 1 & 3 & \multirow{3}{*}{$3 \times 3$} & & & 7 \\
\hline & 4 & 3 & 5 & & & & 8 \\
\hline & 11 & 9 & 7 & & & & 9 \\
\hline & 9 & 18 & 3 & \multirow{3}{*}{$5 \times 5$} & \multirow{7}{*}{ 承: } & & 10 \\
\hline & 5 & 27 & 5 & & & & 11 \\
\hline & 14 & 35 & 7 & & & & 12 \\
\hline & 5 & 12 & 3 & \multirow{3}{*}{$4 \times 4$} & & & 13 \\
\hline & 2 & 21 & 5 & & & & 14 \\
\hline & 9 & 30 & 7 & & & & 15 \\
\hline & 2 & 7 & 3 & $3 \times 3$ & & & 16 \\
\hline
\end{tabular}


مجلة البحوث فى مجالات التربية النوعية

\begin{tabular}{|c|c|c|c|c|c|c|}
\hline 1 & 14 & 5 & & & & 17 \\
\hline 5 & 25 & 7 & & & & 18 \\
\hline 21 & 13 & 3 & \multirow{3}{*}{$5 \times 5$} & \multirow{9}{*}{ 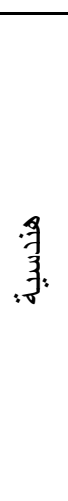 } & \multirow{18}{*}{ 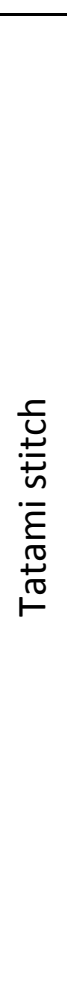 } & 19 \\
\hline 17 & 23 & 5 & & & & 20 \\
\hline 24 & 30 & 7 & & & & 21 \\
\hline 17 & 8 & 3 & \multirow{3}{*}{$4 \times 4$} & & & 22 \\
\hline 12 & 15 & 5 & & & & 23 \\
\hline 21 & 26 & 7 & & & & 24 \\
\hline 12 & 4 & 3 & \multirow{6}{*}{$5 \times 5$} & & & 25 \\
\hline 8 & 10 & 5 & & & & 26 \\
\hline 17 & 19 & 7 & & & & 27 \\
\hline 15 & 28 & 3 & & \multirow{9}{*}{ 被: } & & 28 \\
\hline 10 & 36 & 5 & & & & 29 \\
\hline 19 & 42 & 7 & & & & 30 \\
\hline 10 & 23 & 3 & \multirow{6}{*}{$3 \times 3$} & & & 31 \\
\hline 6 & 30 & 5 & & & & 32 \\
\hline 15 & 40 & 7 & & & & 33 \\
\hline 6 & 16 & 3 & & & & 34 \\
\hline 3 & 25 & 5 & & & & 35 \\
\hline 10 & 34 & 7 & & & & 36 \\
\hline 25 & 24 & 3 & \multirow{3}{*}{$5 \times 5$} & \multirow{9}{*}{. } & \multirow{18}{*}{ 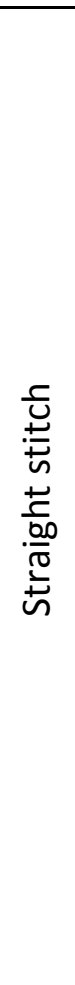 } & 37 \\
\hline 22 & 32 & 5 & & & & 38 \\
\hline 26 & 38 & 7 & & & & 39 \\
\hline 22 & 17 & 3 & \multirow{3}{*}{$4 \times 4$} & & & 40 \\
\hline 18 & 26 & 5 & & & & 41 \\
\hline 25 & 34 & 7 & & & & 42 \\
\hline 18 & 11 & 3 & \multirow{6}{*}{$5 \times 5$} & & & 43 \\
\hline 13 & 20 & 5 & & & & 44 \\
\hline 22 & 29 & 7 & & & & 45 \\
\hline 20 & 37 & 3 & & \multirow{9}{*}{ 寻: } & & 46 \\
\hline 16 & 43 & 5 & & & & 47 \\
\hline 23 & 45 & 7 & & & & 48 \\
\hline 16 & 31 & 3 & \multirow{3}{*}{$4 \times 4$} & & & 49 \\
\hline 11 & 39 & 5 & & & & 50 \\
\hline 20 & 44 & 7 & & & & 51 \\
\hline 11 & 26 & 3 & \multirow{3}{*}{$3 \times 3$} & & & 52 \\
\hline 7 & 33 & 5 & & & & 53 \\
\hline 16 & 41 & 7 & & & & 54 \\
\hline
\end{tabular}


تشير نتائج الجدول (20) إلي أن العلاقة الارتباطية بين ترتيب كل من المتخصصين والمستهلكات لعينات أقمشة الملابس الخفيفة (الجورجيت) المطرزة حيث بلغت قيمة (ر) (0.327) وهي دالة إحصائياً عند مستوي دلالة (0.05) وهي علاقة طردية أي أن هناك توافق بين التقييم من الناحية العلمية والعملية. وبذلك يمكن للباحثة قبول الفرض السابع من فروض البحث والذي ينص على: توجد علاقة ارتباطية بين ترتيب المتخصصين وترتيب المستهكات لعينات أقششة الملابس

الخفيفة المطرزة.

رابعاً: نتائج الخواص الميكانيكية لعينات أقمشة الملابس الخفيفة المطرزة: تأثير متغيرات البحث علي خواص (قوة الثد، نسبة الاستطالة) لأقمشة الملابس الخفيفة المستخدمة تحت البحث: لابريز تم عمل تحليل التباين (ANOVA) لدراسة تأثير اختلاف متغيرات البحث وهي (نوع غرزة التطريز الآلى ، نوع الوحدة الزخرفية المستخدمة ، حجم الوحدة الزخرفية المستخدمة، عدد الوحدات الزخرفية فى المساحة المطرزة) علي: قوة الثد (كجم)، نسبة الاستطالة (\%) لأقشة الملابس الخفيفة (الجورجيت). ويرجع التأثير سواء كان معنوي أو غير معنوي إلي أقل قيمة المعنوية المحسوبة (P-Level) فإذا كانت قيمتها أقل من أو يساوي (0.05) يكون هناك ثأثير معنوي علي الخاصية المدروسة أما إذا كانت أكبر من (0.05) يكون هناك تأثنر غير معنوي علي الخاصية المدروسة، والجدول التالي يوضح متوسطات نتائج الاختبارات تحت البحث. جدول (21) متوسطات نتائج الاختبارات الميكانيكية لأقمشة الملابس الجورجيت تحت البحث

\begin{tabular}{|c|c|c|c|c|c|c|}
\hline $\begin{array}{c}\text { ناستطالة } \\
\text { ن) }\end{array}$ & قوة & الزعاحة المرفية فى المدرة & حجم الوحدة & $\begin{array}{c}\text { الزوحدة } \\
\text { الزخرفية }\end{array}$ & نوع غرزة & رقبم \\
\hline 40 & 24 & - & - & & - & الضابطة \\
\hline 40 & 26 & 3 & \multirow{3}{*}{$5 \times 5$} & \multirow{6}{*}{. } & \multirow{6}{*}{ 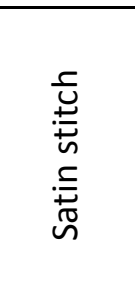 } & 1 \\
\hline 37.5 & 16 & 5 & & & & 2 \\
\hline 45 & 16 & 7 & & & & 3 \\
\hline 40 & 20 & 3 & & & & 4 \\
\hline 40 & 14 & 5 & & & & 5 \\
\hline 45 & 18 & 7 & & & & 6 \\
\hline
\end{tabular}


مجلة البحوث في مجالات التربية النوعية

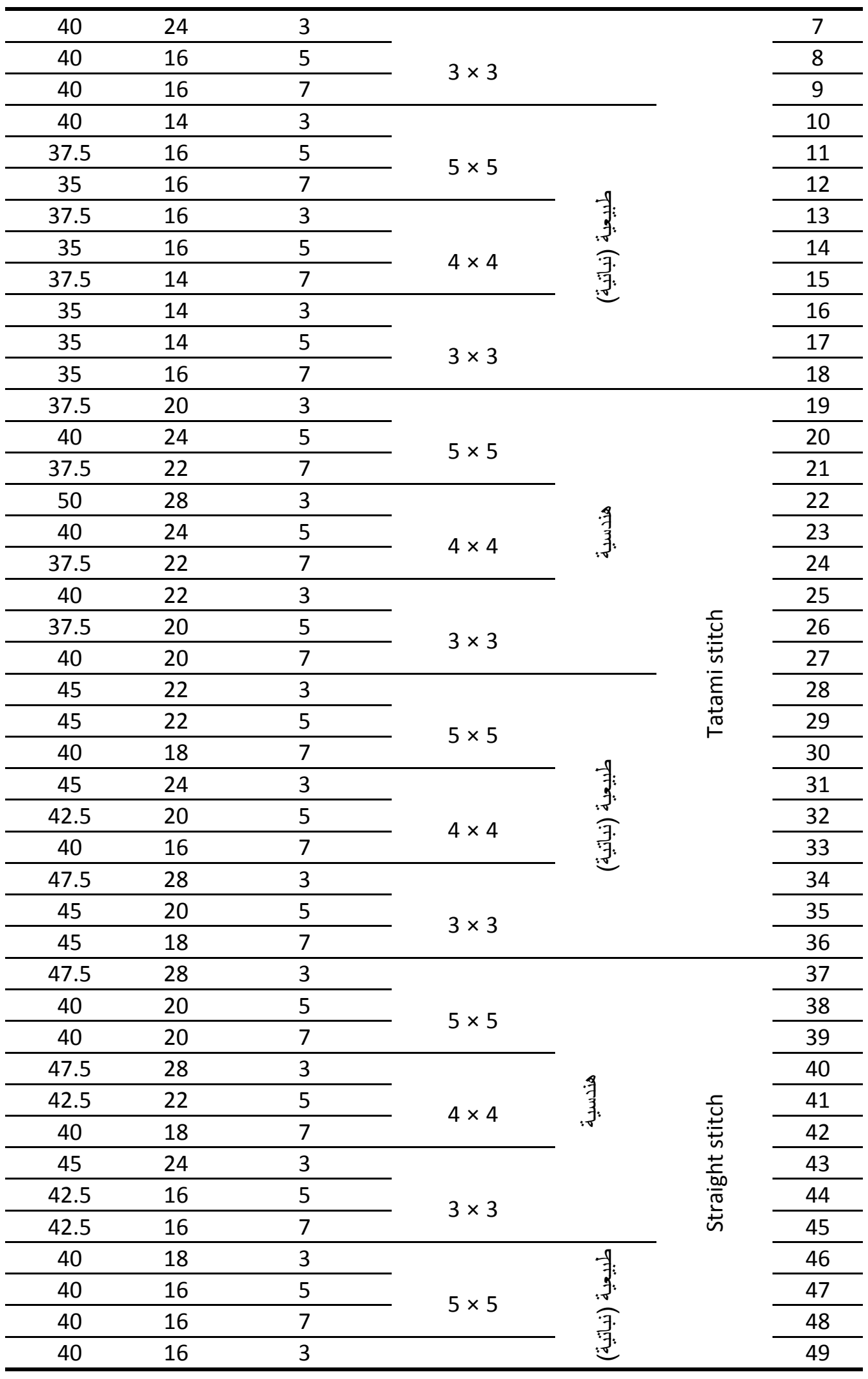


مجلة البحوث فى مجالات التربية النوعية

\begin{tabular}{|c|c|c|c|c|}
\hline 45 & 20 & 5 & \multirow[t]{2}{*}{$4 \times 4$} & 50 \\
\hline 45 & 20 & 7 & & 51 \\
\hline 40 & 16 & 3 & \multirow{3}{*}{$3 \times 3$} & 52 \\
\hline 40 & 18 & 5 & & 53 \\
\hline 40 & 16 & 7 & & 54 \\
\hline
\end{tabular}

جدول (22): تحليل التباين الأحادي في اتجاه (N - Way ANOVA) لتأثثر متغيرات البحث علي قوة الثد (كجم)

\begin{tabular}{|c|c|c|c|c|c|}
\hline مستوي المغنوية & قيمة "ف" & متوسط المربعات & درجات الحرية & مجموع المربعات & مصدر التباين \\
\hline .000 & 14.361 & 107.630 & 2 & 215.259 & نوع غرزة التطريز الآلى \\
\hline .000 & 15.814 & 118.519 & 1 & 118.519 & نوع الوحدة الزخرفية \\
\hline .391 & .959 & 7.185 & 2 & 14.370 & حجم الوحتدة الزخرفية \\
\hline \multirow[t]{3}{*}{.000} & 9.973 & 74.741 & 2 & 149.481 & عدد الوحدات الزخرفية \\
\hline & & 7.494 & 46 & 344.741 & تباين الخطأ \\
\hline & & & 53 & 842.370 & التباين الكلي \\
\hline
\end{tabular}

ويتضح من نتائج جدول (22) إلي ما يلى:

1. يوجد فرق دال إحصائياً عند مستوي (0.01) بين نوع غرزة التطريز الآلى في

تأثنيرها علي قوة الثد (كجم).

2. يوجد فرق دال إحصائياً عند مستوي (0.01) بين نوع الوحدة الزخرفية

المستخدمة في تأثيرها علي قوة الثد (كجم).

3. لا يوجد فرق دال إحصائياً بين حجم الوحدة الزخرفية المستخدمة في تأثنرها

علي قوة الثد (كجم)، وهذا يتفق مع تحليل التباين لمتوسط نتائج تقييم عينات أقششة الملابس الجورجيث وفقا $\square$ لحجم الوحدة الزخرفية في ضوء

آراء المتخصصين والموضح بجدول (12).

4. يوجد فرق دال إحصائياً عند مستوي (0.01) بين عدد الوحدات الزخرفية في

تأثنيرها علي قوة الثد (كجم).

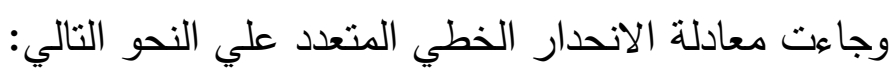

$Y=26.898+1.278$ X1 - 2.963 X2 - 0.444 X3 - 0.972 X4

$R^{2}=0.591, R=0.768$ 
تشير قيمة معامل التحديد (R²) إلى نسبة التباين التى ترجع إلى إنحدار المتغير التابع وهو قوة الثد (كجم) على المتغيرات المستقلة وكلما ارتفعت قيمه (R²) دل ذلك على إنى ارتفاع النسبة المئوبة التى تسهم بها المتغيرات المستقلة على المتغير التابع حيث بلغت قيمة (R2) المستخدمة ، حجم الوحدة الزخرفية المستخدمة، عدد الوحدات الزخرفية، تفسر 59\% من التباينات الكلية فى قوة الثد (كجم) تفسرها العلاقة الخطية وأن النسبة المكملة 41 ترجع الى عوامل عشوائية. حيث:

Xمثل نوع غرزة التطريز الآلى

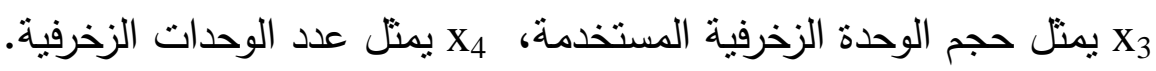

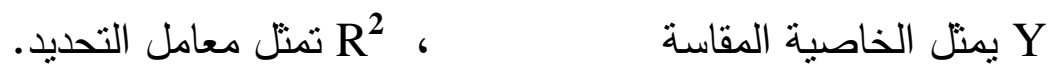
R يمنل معامل الارتباط بين بين الخاصية المقاسة والمتغيرات. وهو بمثن ارتباط طردي بين قوة الثد (كجم) ومتغيرات البحث المختلفة. جدول (23): المتوسطات والانحرافات المعيارية لمتغيرات البحث في تأثيرها علي قوة الثد (كجم)

\begin{tabular}{|c|c|c|c|c|}
\hline الترتيب & الانحراف المعياري & المتوسط & المستويات & المتغير ات \\
\hline 3 & 3.37 & 16.78 & Satin stitch & \multirow{3}{*}{ نوع غرزة التطريز الآلي } \\
\hline 1 & 3.16 & 21.67 & Tatami stitch & \\
\hline 2 & 3.94 & 19.33 & Straight stitch & \\
\hline 1 & 4.08 & 20.74 & هندسية & \multirow{2}{*}{ نوع الوحدة الزخرفية } \\
\hline 2 & 3.34 & 17.78 & طبيعية & \\
\hline 2 & 3.93 & 19.44 & 5 × 5 سم & \multirow{3}{*}{ حجم الوحدة الزخرفية } \\
\hline 1 & 4.28 & 19.78 & 4 4 × سم & \\
\hline 3 & 3.87 & 18.56 & 3 3 × & \\
\hline 1 & 5.02 & 21.56 & 3 وحدات & \multirow{3}{*}{ عدد الوحدات الزخرفية } \\
\hline 2 & 3.20 & 18.56 & 5 وحدات & \\
\hline 3 & 2.30 & 17.67 & 7 وحدات & \\
\hline
\end{tabular}




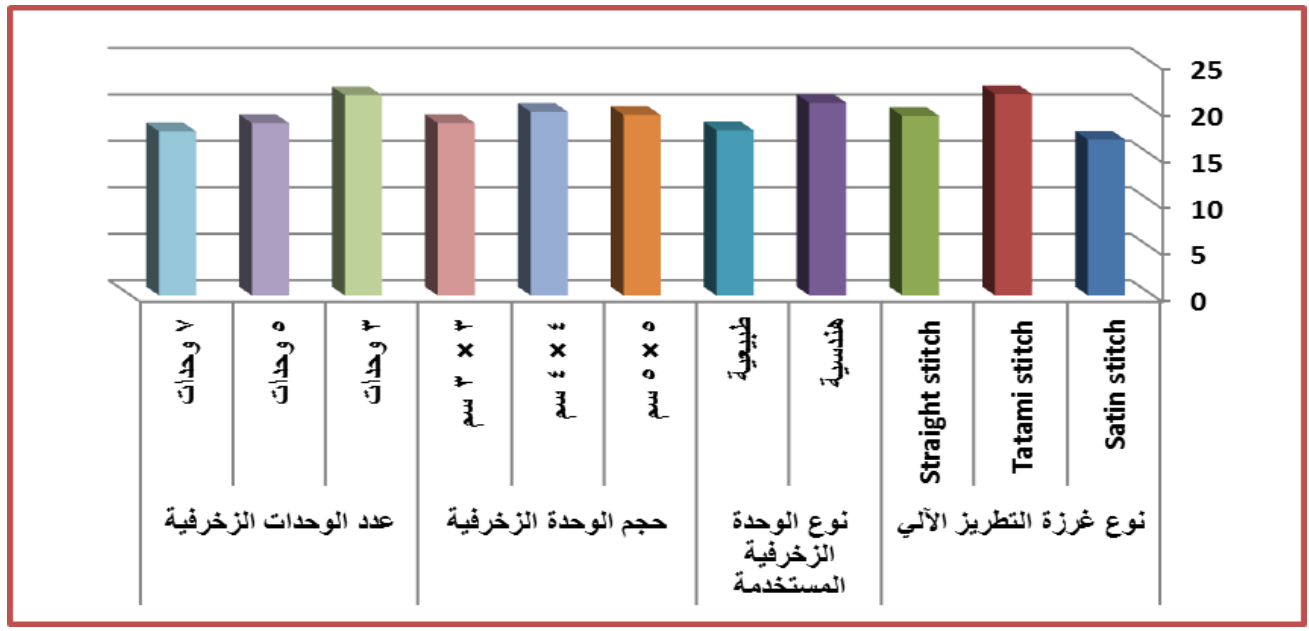

شكل (13) المتوسطات لمتغيرات البحث في تأثيرها علي قوة الثد (كجم)

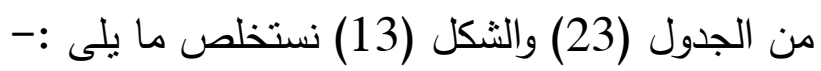

- يمكن ترنيب نوع غرزة التطريز الآلي في نأثيرها علي قوة الثد (كجم) كالتالي: ، Satin stitch ، Straight stitch ، Tatami stitch LSD اختبار

- يمكن ترتيب نوع الوحدة الزخرفية المستخدمة في تأثثرها علي قوة الثد (كجم) كالتالي: هندسية، طبيعية، وهذا يتفق مع ترتيب نوع الوحدة الزخرفية لعينات أقششة الملابس الجورجيت وفقاً لآراء المتخصصين والموضح بجدول (11)

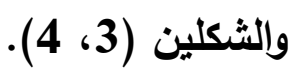

- - يمكن ترتيب حجم الوحدة الزخرفية في تأثثرها علي قوة الثند (كجم) كالتالي:

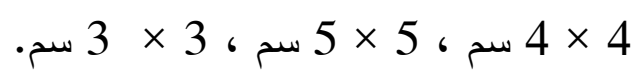

- - يمكن ترتيب عدد الوحدات الزخرفية في تأثنرها علي قوة الثد (كجم) كالتالي:

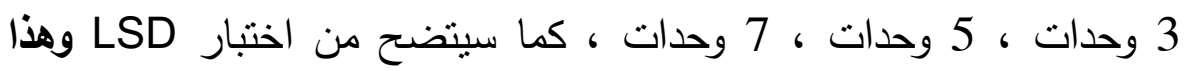
يتفق مع ترتيب عدد الوحدات الزخرفية لعينات أقشة الملابس الجورجيت وفقاً لآراء المتخصصين والموضح بجدول (15) والثكلين (7، 8). LSD ولتحديد اتجاه الفروق بين نوع غرزة التطريز الآلي قامت الباحثة بتطبيق إختبار (أقل فرق معنوي) للمقارنات المتعددة، وذلك علي النحو المبين في جدول (24). جدول (24) الفروق بين المتوسطات باستخدام اختبار LSD (أقل فرق معنوي) للمقارنات المتعددة

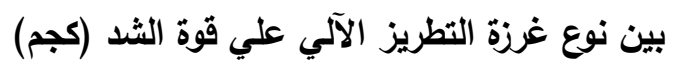


مجلة البحوث فى مجالات التربية النوعية

(3) Straight stitch

$19.33=$ ?

$2.5556^{*}$

$2.3333^{*}$
(2) Tatami stitch

$21.67=$ ?

$4.8889^{*}$
(1) Satin stitch $16.78=$ ?

نوع غرزة التطريز الآلي

$16.78=$ (1) Satin stitch

$21.67=$ (2) Tatami stitch

$19.33=$ (3) Straight stitch

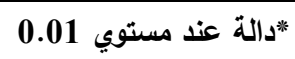

نتبين من النتائج التي يلخصها الجدول (24) وجود فروق دالة بين نوع غرزة التطريز الآلي في تأثيره علي قوة الثد (كجم) وبمكن للباحثة ترثيب نوع غرزة التطربز الآلي وفق تأثيره في ضوء المتوسطات باستخدام اختبار LSD كالتالي: Tatami stitch،

- Satin stitch ،Straight stitch

ولتحديد اتجاه الفروق بين عدد الوحدات الزخرفية قامت الباحثة بتطبيق إختبار LSD (أقل فرق معنوي) للمقارنات المتعددة، وذلك علي النحو المبين في جدول (25). جدول (25) الفروق بين المتوسطات باستخدام اختبار LSD (أقل فرق معنوي) للمقارنات المتعددة بين عدد الوحدات الزخرفية علي قوة الثد (كجم)

\begin{tabular}{|c|c|c|c|}
\hline 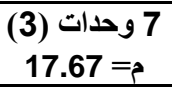 & 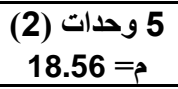 & $\begin{array}{c}3 \text { وحدات } 21.56=2 \\
\text { 21.5 }\end{array}$ & عدد الوحدات الزخرفية \\
\hline $3.8889^{*}$ & $3.0000^{*}$ & & 3 وحدات (1) م= 21.56 \\
\hline .8889 & & & 5 وحدات (2) م= 18.56 \\
\hline & & & 7 وحدات (3) م= 17.67 \\
\hline
\end{tabular}

نتبين من النتائج التي يلخصها الجدول (25) وجود فروق دالة بين عدد الوحدات الزخرفية في تأثيره علي قوة الثد (كجم) ويمكن للباحثة ترتيب عدد الوحدات الزخرفية وفق تأثيره في ضوء المتوسطات باستخدام اختبار LSD كالتالي: 3 وحدات، 5 وحدات، 7 وحدات.

\section{ثانباً- تأثير متغيرات البحث علي نسبة الاستطالة (\%):}

جدول (26): تحليل التباين الأحادي في اتجاه (N - Way ANOVA) لتأثير متغيرات البحث علي نسبة الاستطالة (\%)

\begin{tabular}{|c|c|c|c|c|c|}
\hline مستوي المعنوية & قيمة "ف" & متوسط المربعات & درجات الحرية & مجموع المربعات & مصدر التباين \\
\hline .003 & 6.773 & 69.560 & 2 & 139.120 & نوع غرزة التطريز الآلى \\
\hline .344 & .913 & 9.375 & 1 & 9.375 & نوع الوحدة الزخرفية \\
\hline .446 & .823 & 8.449 & 2 & 16.898 & حجم الوحدة الزخرفية \\
\hline
\end{tabular}


مجلة البحوث فى مجالات التربية النوعية

\begin{tabular}{|c|c|c|c|c|c|}
\hline .030 & 1.904 & 19.560 & 2 & 39.120 & عدد الوحدات الزخرفية \\
\hline & & 10.271 & 46 & 472.454 & تباين الخطأ \\
\hline & & & 53 & 676.968 & التباين الكلي \\
\hline
\end{tabular}

ويتضح من نتائج جدول (26) إلي ما يلى:

1. يوجد فرق دال إحصائياً عند مستوي (0.01) بين نوع غرزة النطريز الآلى في

تأثيرها علي نسبة الاستطالة (\%).

2. لا يوجد فرق دال إحصائياً بين نوع الوحدة الزخرفية المستخدمة في تأثيرها علي الاني

نسبة الاستطالة (\%).

3. لا يوجد فرق دال إحصائياً بين حجم الوحدة الزخرفية المستخدمة في تأثيرها

علي نسبة الاسنطالة (\%) وهذا يتقق مع تحليل التباين لمتوسط نتائج تقييم

عينات أقششة الملابس الجورجيت وفقا لحجم الوحدة الزخرفية في ضوء

آراء المتخصصين والموضح بجدول (12).

4. يوجد فرق دال إحصائياً عند مستوي (0.05) بين عدد الوحدات الزخرفية في

تأثثيرها علي نسبة الاسنطالة (\%).

وجاءت معادلة الانحدار الخطي المتعدد علي النحو التالي: لنالئه

$Y=40.775+1.736 X_{1}-0.833 X_{2}-0.069 X_{3}-0.451 X_{4}$

$\mathbf{R}^{2}=0.302, R=0.549$

تشير قيمة معامل التحديد (R2) إلى نسبة التباين التى ترجع إلى إنحدار المتغير التابع

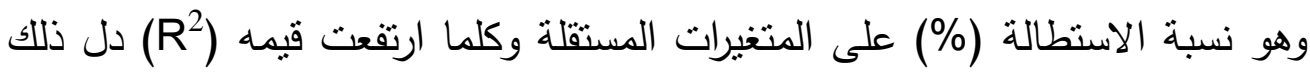
على ارتفاع النسبة المئوية التى تسهم بها المتغيرات المستقلة على المتغير التابع حيث بلغت قيمة (R2=(R2)

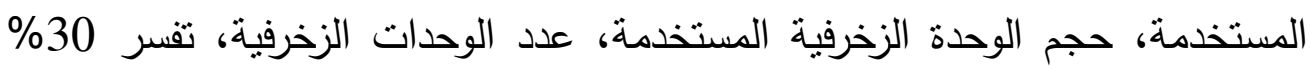
من التباينات الكلية فى نسبة الاستطالة (\%) تفسرها العلاقة الخطبة وأن النسبة المكملة 70 ترجع الى عوامل عشوائية. حيث:

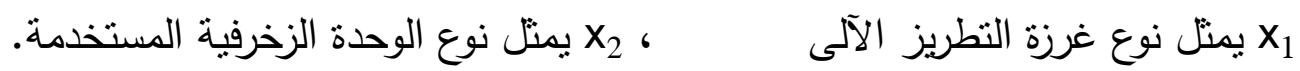

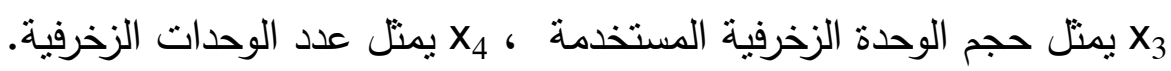


R يمثل معامل الارتباط بين بين الخاصية المقاسة والمتغيرات. وهو يمثل ارتباط طردي بين نسبة الاستطالة (\%) ومتغيرات البحث المختلفة. جدول (27): المتوسطات والانحرافات المعيارية لمتغيرات البحث في تأثيرها علي نسبة الاستطالة (\%)

\begin{tabular}{|c|c|c|c|c|}
\hline الترتيب & المعياري & المتوسط & المستويات & المتغيرات \\
\hline 3 & 3.12 & 38.61 & Satin stitch & \multirow{3}{*}{ نوع غرزة التطريز الآلي } \\
\hline 2 & 3.79 & 41.94 & Tatami stitch & \\
\hline 1 & 2.75 & 42.08 & Straight stitch & \\
\hline 1 & 3.35 & 41.30 & هندسية & \multirow{2}{*}{ نوع الوحدة الزخرفية } \\
\hline 2 & 3.80 & 40.46 & طبيعية & \\
\hline 3 & 3.24 & 40.42 & 5 × 5 سم & \multirow{3}{*}{ حجم الوحدة الزخرفية } \\
\hline 1 & 3.93 & 41.67 & 4 × 4 سم & \\
\hline 2 & 3.59 & 40.56 & 3 × 3 سم & \\
\hline 1 & 4.22 & 42.08 & 3 & \multirow{3}{*}{ عدد الوحدات الزخرفية } \\
\hline 2 & 3.08 & 40.28 & 5 وحدات & \\
\hline 2 & 3.20 & 40.28 & 7 وحدات & \\
\hline
\end{tabular}

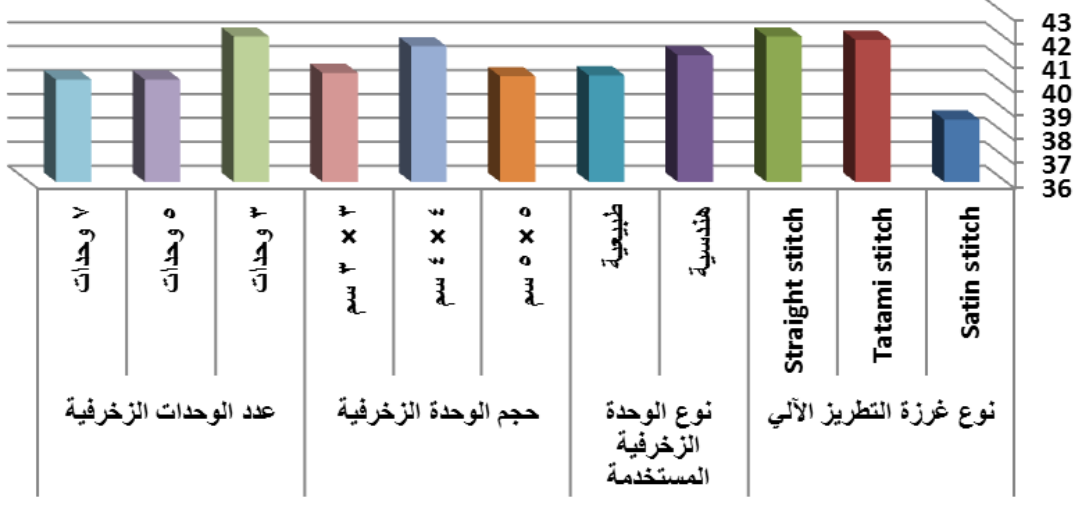

شكل (14) المتوسطات لمتغيرات الدراسة في تأثيرها علي نسبة الاستطالة (\%) من الجدول (27) والثكل (14) نستخلص ما يلى :- 
- يمكن ترتيب نوع غرزة النطريز الآلي في تأثيرها علي نسبة الاستطالة (\$)

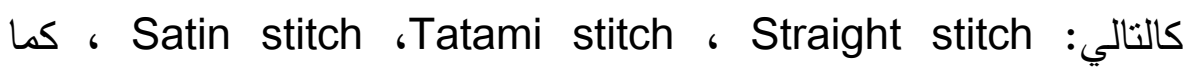

$$
\text { LSD تيتضح من اختبار }
$$

- يمكن ترتيب نوع الوحدة الزخرفية المستخدمة في تأثنيرها علي نسبة الاستطالة (\%) كالتالي: هندسية، طبيعية.

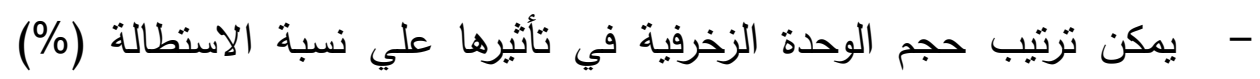

$$
\text { كالتالي: } 4 \text { × } 4 \text { سم، } 3 \text { × } 3 \text { سم سم ، } 5 \text { × } 5 \text { × } 5 \text { سم. }
$$

- يمكن تزتيب عدد الوحدات الزخرفية في تأثيرها علي نسبة الاستطالة (\%)

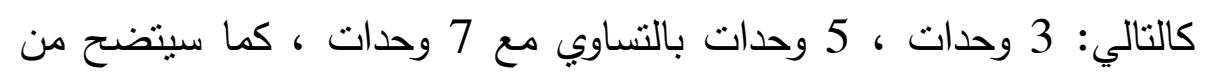

\section{LSD اختبار}

LSD ولتحديد اتجاه الفروق بين نوع غرزة التطريز الآلي قامت الباحثة بتطبيق إختبار (أقل فرق معنوي) للمقارنات المتعددة، وذلك علي النحو المبين في جدول (28). جدول (28) الفروق بين المتوسطات باستخدام اختبار LSD (أقل فرق معنوي) للمقارنات المتعددة

\begin{tabular}{|c|c|c|c|}
\hline $\begin{array}{c}\text { (3) Straight stitch } \\
42.08=?\end{array}$ & $\begin{array}{c}\text { (2) Tatami stitch } \\
41.94=?\end{array}$ & $\begin{array}{l}\text { (1) Satin stitch } \\
38.61=?\end{array}$ & نوع غرزة التطريز الآلي \\
\hline $3.4722^{*}$ & $3.3333^{*}$ & & $38.61=$ (1) Satin stitch \\
\hline \multirow[t]{2}{*}{.1389} & & & $41.94=$ = (2) Tatami stitch \\
\hline & & & $42.08=$ (3) Straight stitch \\
\hline
\end{tabular}

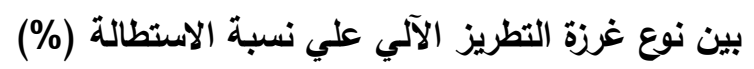

نتبين من النتائج التي يلخصها الجدول (28) وجود فروق دالة بين نوع غرزة التطريز الآلي في تأثثيره علي نسبة الاسنطالة (\%) ويمكن للباحثة ترتيب نوع غرزة التطريز الآلي وفق تأثيره في ضوء المتوسطات باستخدام اختبار LSD كالتالي: Straight Satin stitch ،Tatami stitch ، stitch النجار، 2008) بأن عملية التطريز تؤثر على الخواص الوظيفية للخامة من (قوة الثد، نسبة الاسنطالة، الصلابة، الوزن).

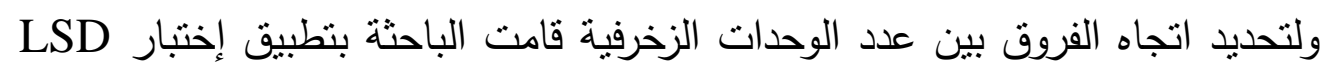
(أقل فرق معنوي) للمقارنات المتعددة، وذلك علي النحو المبين في جدول (29). 
جدول (29) الفروق بين المتوسطات باستخدام اختبار LSD (أقل فرق معنوي) للمقارنات المتعددة

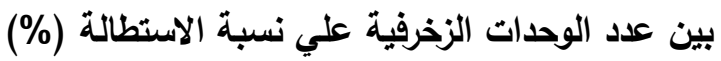

\begin{tabular}{|c|c|c|c|}
\hline 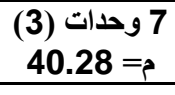 & $\begin{array}{c}5 \text { و } 5 \text { وحدات } 40.28 \text { = } \\
\end{array}$ & $\begin{array}{c}3 \text { (1) } 3 \text { (1 } 32.08=8 \\
42.5\end{array}$ & عدد الوحدات الزخرفية \\
\hline 1.8056 & 1.8056 & & 3 وحدات (1) م= 42.08 \\
\hline \multirow[t]{2}{*}{.0000} & & & 5 وحدات (2) م= 40.28 \\
\hline & & & 7 وحدات (3) م= 40.28 \\
\hline
\end{tabular}

نتبين من النتائج التي يلخصها الجدول (29) وجود فروقً دالة بين عدد الوحدات الزخرفية في تأثثره علي نسبة الاستطالة (\%) ويمكن للباحثة ترتيب عدد الوحدات

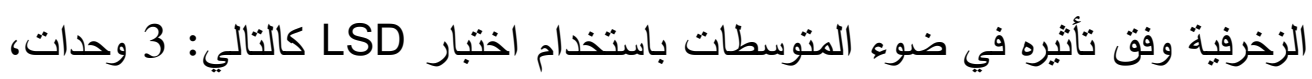

$$
5 \text { وحدات بالتساوي مع } 7 \text { وحدات. }
$$

ثالثاً: تقيبم الجودة الكلبة لعينات أقشثة الملابس الخفيفة المطزة تحت البحث: تم عمل تقييم لجودة الأقشة المطرزة تحت البحث لملائمتها للغرض الوظيفي، لاختيار أنسب متغيرات البحث (نوع غرزة التطريز الآلى ، نوع الوحدة الزخرفية المستخدمة ،

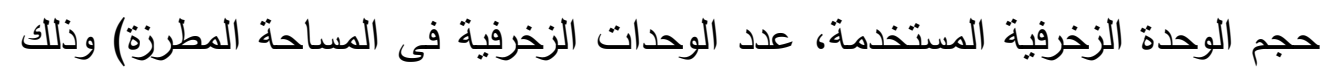
باستخدام أشكال الرادار Chart Radar متعدد المحاور ليعبر عن تقييم الجودة الكلية للأقشة المطرزة تحت البحث من خلال استخدام الخواص الأتية: قوة الثد (كجم)، نسبة الاسنطالة (\%) وذلك بتحويل نتائج قياسات هذه الخواص إلي قيم مقارنة، حيث

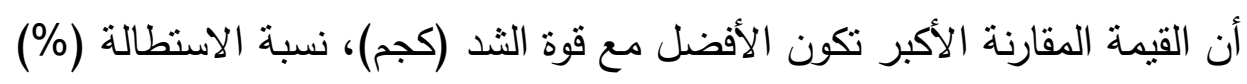

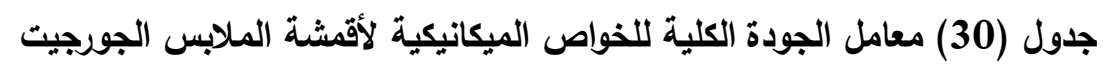

\begin{tabular}{|c|c|c|c|c|c|c|c|c|}
\hline $\begin{array}{c}\text { معامل } \\
\text { الجودة } \\
\text { \% }\end{array}$ & المثالية & $\begin{array}{c}\text { الاستطالة } \\
\text { \% }\end{array}$ & \% قوة الثد & الزخرفية فى المدات & الزخرة & الزخدة & $\begin{array}{c}\text { غنطزة } \\
\text { التمريز } \\
\end{array}$ & رقينة \\
\hline 86.43 & 172.86 & 80.00 & 92.86 & 3 & \multirow{3}{*}{$5 \times 5$} & \multirow{6}{*}{ 畓 } & \multirow{6}{*}{ 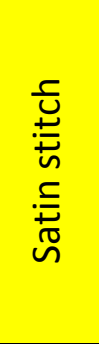 } & 1 \\
\hline 66.07 & 132.14 & 75.00 & 57.14 & 5 & & & & 2 \\
\hline 73.57 & 147.14 & 90.00 & 57.14 & 7 & & & & 3 \\
\hline 75.71 & 151.43 & 80.00 & 71.43 & 3 & \multirow{3}{*}{$4 \times 4$} & & & 4 \\
\hline 65.00 & 130.00 & 80.00 & 50.00 & 5 & & & & 5 \\
\hline 77.14 & 154.29 & 90.00 & 64.29 & 7 & & & & 6 \\
\hline
\end{tabular}


مجلة البحوث في مجالات التربية النوعية

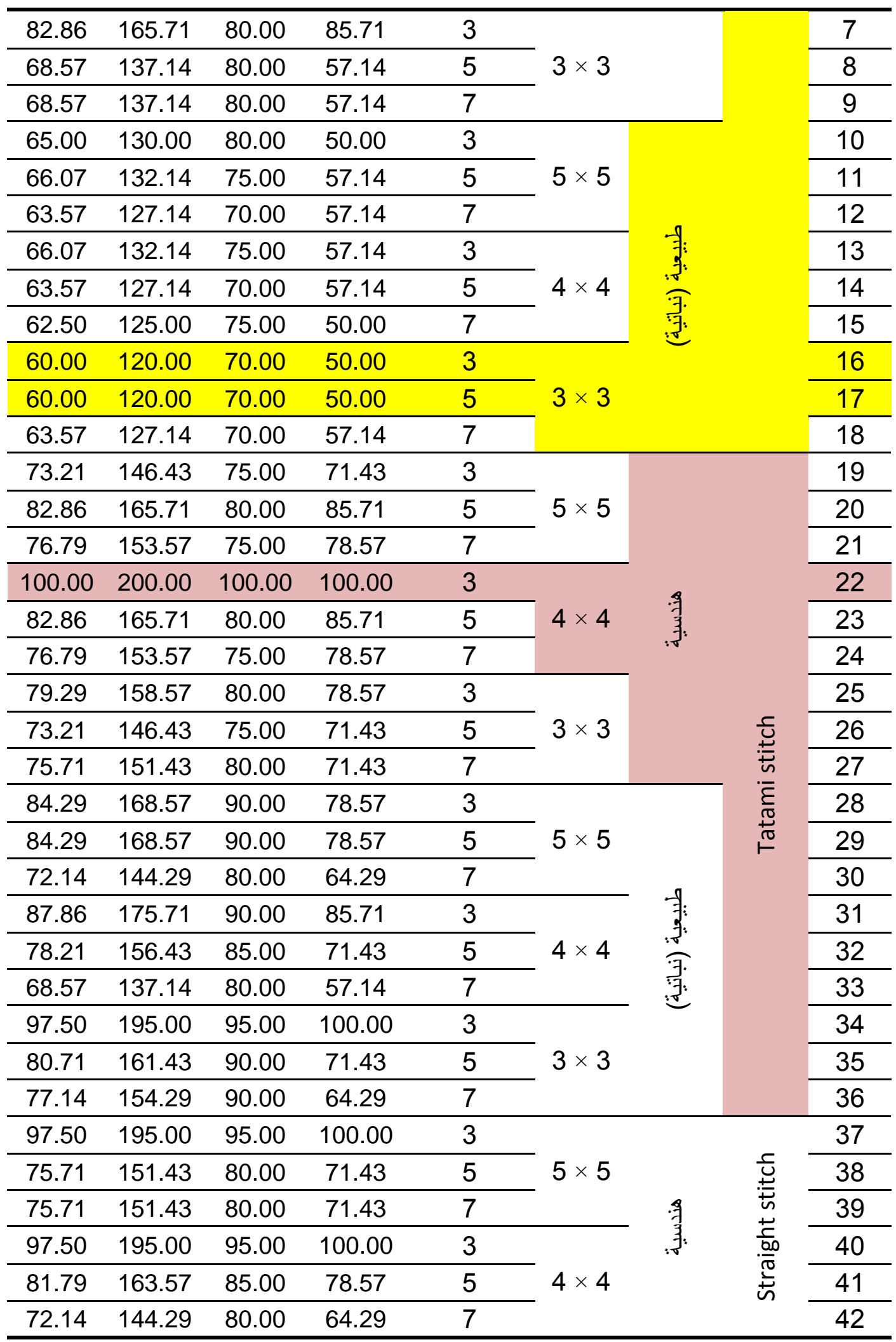


مجلة البحوث فى مجالات التربية النوعية

\begin{tabular}{|c|c|c|c|c|c|c|c|}
\hline 87.86 & 175.71 & 90.00 & 85.71 & 3 & \multirow{3}{*}{$3 \times 3$} & & 43 \\
\hline 71.07 & 142.14 & 85.00 & 57.14 & 5 & & & 44 \\
\hline 71.07 & 142.14 & 85.00 & 57.14 & 7 & & & 45 \\
\hline 72.14 & 144.29 & 80.00 & 64.29 & 3 & \multirow{7}{*}{\multicolumn{2}{|c|}{ 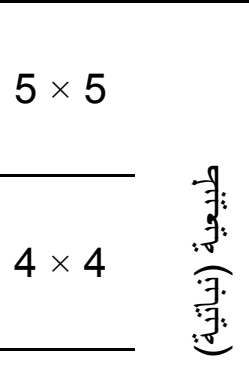 }} & 46 \\
\hline 68.57 & 137.14 & 80.00 & 57.14 & 5 & & & 47 \\
\hline 68.57 & 137.14 & 80.00 & 57.14 & 7 & & & 48 \\
\hline 68.57 & 137.14 & 80.00 & 57.14 & 3 & & & 49 \\
\hline 80.71 & 161.43 & 90.00 & 71.43 & 5 & & & 50 \\
\hline 80.71 & 161.43 & 90.00 & 71.43 & 7 & & & 51 \\
\hline 68.57 & 137.14 & 80.00 & 57.14 & 3 & & & 52 \\
\hline 72.14 & 144.29 & 80.00 & 64.29 & 5 & \multirow[t]{2}{*}{$3 \times 3$} & & 53 \\
\hline 68.57 & 137.14 & 80.00 & 57.14 & 7 & & & 54 \\
\hline
\end{tabular}

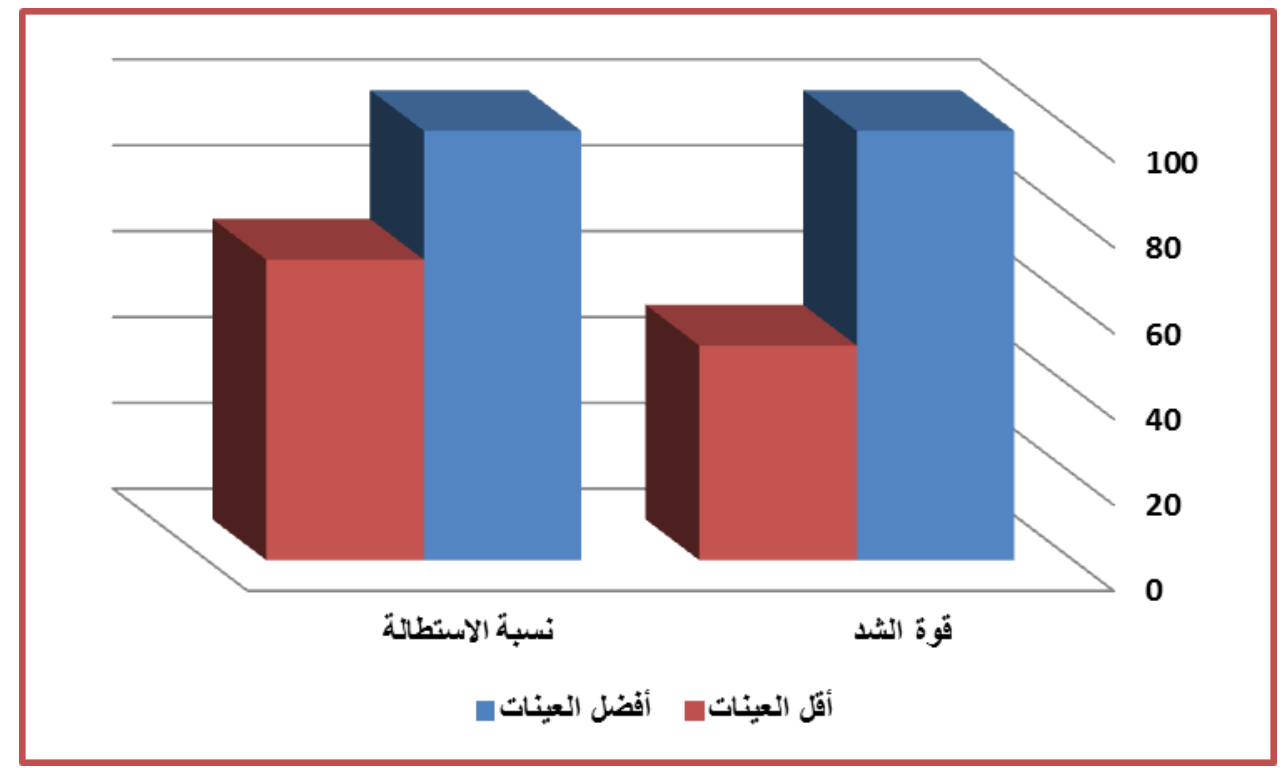

شكل (15) معامل الجودة الكلية للخواص الميكانيكية لأفضل وأقل العينات لأقشة الملابس الجورجيت

$$
\begin{aligned}
& \text { المطرزة تحت البحث } \\
& \text { من الجدول (30) والثكل (15) يتضح أن: }
\end{aligned}
$$

1 - أفضل العينات رقم (22) بمساحة مثالية (200) ومعامل الجودة

(100)\% بنوع غرزة التطريز الآلي (Tatami stitch) ونوع الوحدة

الزخرفية (هندية) وحجم الوحدة الزخرفية ( 4×4 سم) وعدد الوحدات

$$
\text { الزخرفية في المساحة المطرزة (3 وحدات). }
$$


2- - أقل العينات رقم (16، 17) بمساحة مثالية (120) ومعامل الجودة (60)\%) بنوع غرزة التطريز الآلي (Satin stitch) ونوع الوحدة الزخرفية (طبيعية) وحجم الوحدة الزخرفية ( 3×3 سم) وعدد الوحدات الزخرفية في المساحة المطرزة (3 وحدات)،(5 وحدات) على التزتيب.

ملخص النتائج: ** بالنسبة لمظهرية وجودة تطريز العينات تحت البحث:

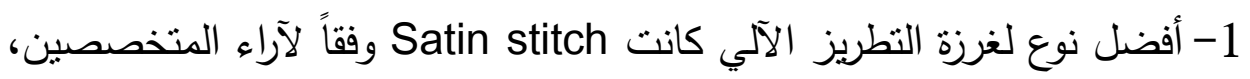
والمستهلكات.

2- أفضل نوع للوحدة الزخرفية كانت (هندسية) وفقاً لآراء المتخصصين، بينما كانت الوحدة الزخرفية (الطبيعية) الأفضل وفقاً لآراء المستهكات. 3- عدم وجود فرق دال إحصائياً بين حجم الوحدة الزخرفية وفقاً لآراء المتخصصين ويتفق ذلك مع نتائج الخواص الميكانيكية للعينات المطرزة تحت البحث، بينما أفضل حجم للوحدة الزخرفية كان (3×3م) وفقاً لآراء المستهلكات.

4- أفضل عدد للوحدات الزخرفية فى المساحة المطرزة كان 3 وحدات وفقاً لآراء المتخصصين، بينما كان عدد 5 وحدات الأفضل وفقاً لآراء المستهكات. 5- وجود توافق بين التقييم من الناحية العلمية والعملية حيث أن العلاقة الارتباطية بين ترتيب المتخصصين والمستهلكات للعينات تحت البحث كانت علاقة طردية ودالة احصائياً.

** * بالنسبة للخواص الميكانيكية(قوة الشد، نسبة الاستطالة) للعينات تحت البحث: * أفضل العينات رقم (22) بمساحة مثالية (200) ومعامل الجودة (100)\% بنوع غرزة التطريز الآلي (Tatami stitch) ونوع الوحدة الزخرفية (هندسية) وحجم الوحدة الزخرفية ( 4×4 سم) وعدد الوحدات الزخرفية في المساحة المطرزة (3 وحدات). 
1- الاستفادة من تكنولوجيا ماكينات التطريز الآلى المتطورة والامكانات غير

المحدودة لتلك الماكينات الحديثة وتوظيفها فى مجال الملابس.

2- عمل مزيد من الأبحاث التجريبية على أنواع أخرى من الأقمشة الخفيفة باستخدام تقنيات إضافية تخدم مجال النطريز الآلى.

3- الحرص على تدريب طلاب قسم الملابس والنسيج بالجامعات المختلفة على

التعامل الأنسب مع الأقشة الخفيفة ذات الطبيعة الخاصة بالتطريز الآلي وقيامهم بزيارات ميدانية لمصانع التطريز الآلى لزيادة مهاراتهم الفنية.

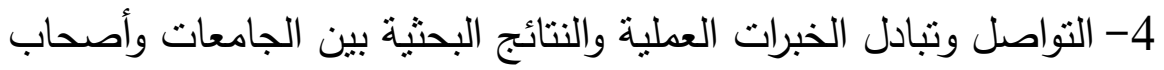
مصانع التطريز الآلى للوصول بالمنتج المصرى لأعلى مستويات الجودة.

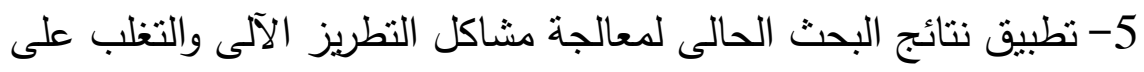
العيوب الفنية الحادثة أثناء عملية النطريز على أقمشة الجورجيت والتى قد التى تتتج من الاختيار الخاطىء ( لنوع غرزة النطريز الآلى - نوع الوحدة الزخرفية - حجم الوحدة الزخرفية- عدد الوحدات الزخرفية فى المساحة المطرزة).

1- إبراهيم، عبير إبراهيم عبد الحميد. (2010). مكملات الملابس فى ضوء تكنولوجيا ماكينات التطريز الآلى وأثرها فى عروض الأزياء. مجلة علوم إيراه وفنون - دراسات وبحوث، جامعة حلوان، مجلد (22)، عدد (2)، أبريل.

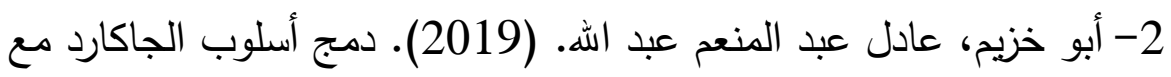

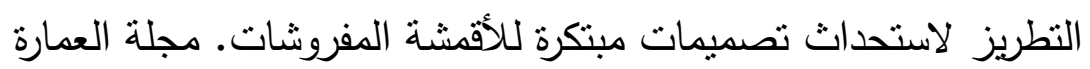
والفنون والعلوم الإنسانية، الجمعية العربية للحضارة والفنون الإسلامية، عدد • (15) 3- أبو موسى، إيهاب فاضل. (2001). تصميم الأزياء والأسس العلمية والفنية المساهمة فى بناء برامج الحاسب الآلى. الطبعة الأولى، دار الحسين، شبين الحين

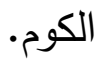


4- أبو هشيمة، مدحت محمد و العطروني، لمياء حسن. (2007). دراسة تأثنر تقنيات التطريز الآلي على مظهرية أقمشة الثيفون. المؤتمر العربي الحادي عثر للاقتصاد المنزلي، كلية الاقتصاد المنزلى، جامعة المنوفية. 5- السلمان، شهزل على أحمد. (2020). توظيف تطبيقات الهواتف الذكية فى تتمية مهارات الطالبات لتقنيات التطريز ـ مجلة الفنون والأدب وعلوم الإنسانيات والاجتماع، كلية الإمارات للعلوم التربوية، عدد (60)، نوفمبر • 6- السيد، غادة عبد الفتاح عبد الرحمن و حمودة ، رانيا محمد أحمد. ( 2018). تأثثر بعض الأساليب النطبيقية على الخواص الوظيفية لأقمشة نربكو اللحمة المخلوطة بالليكرا للتغلب على مشاكل وعيوب التطريز الآلي. المؤتمر العلمي الخامس والدولي الثالث، كلية التربية النوعية، جامعة عين شمس. 7- الطوبشى، سامية محمد محمد. (2000). مدى ملائمة غرز التطريز الآلى للتراكيب النسجية المختلفة وتوظيفها لنزين الملابس الجاهزة. مجلة الاقتصاد المنزلى، كلية الاقتصاد المنزلى، جامعة المنوفية، مجلد (10)، عدد (4). 8- اليمانى، سهيلة حسن عبد الله و قاضى، أفنان رياض عبد المنعم. (2011). رؤية تشكيلية مبتكرة لغرز التطريز اليدوى باستخدام الحاسب الآلى. مجلة بحوث فى التربية النوعية، كلية التربية النوعية، جامعة القاهرة، عدد (17)، • يناير 9- توفيق، نشوة عبد الرؤوف و النجار ، أسمهان إسماعيل. (2008). أثز عملية التطريز على الخواص الوظيفية للخامة باختلاف بعض عوامل التركيب البنائى. مجلة الاقتصاد المنزلى، كلية الاقتصاد المنزلى، جامعة المنوفية،

$$
\text { مجلد (18)، عدد (1). }
$$

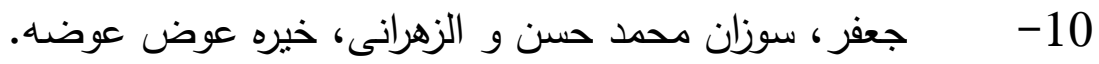
(2011). دراسة زخارف الطراز الأندلسى وتوظيفها فى إثراء الملابس النسائية بالتطريز الآلى. مجلة بحوث التربية النوعية، جامعة المنصورة، عدد (19)،

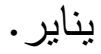


11- ربى، سحر حربى محمد و سليمان، هالة سليمان السيد. (2018).

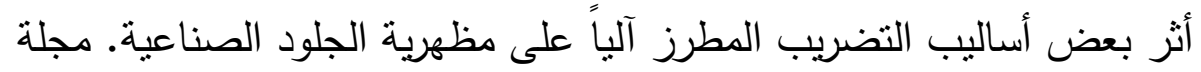
التصميم الدولية، كلية الفنون التطبيقية، جامعة حلوان، مجلد (8)، عدد (4)، أكتوبر •

12- حسن، لمياء حسن على. (2002). ابتكار تصميمات مقتبسة من الزخارف العثمانية وتوظيفها لإثراء تكنولوجيا التصميم الزخرفى والتطريز باستخدام الحاسب الآلى. رسالة دكتوراه- غير منشورة- كلية الاقتصاد المنزلى، جامعة حلوان.

.

أقمشة الساتان. مجلة بحوث التربية النوعية، جامعة المنصورة، عدد (14)، مايو - مايو

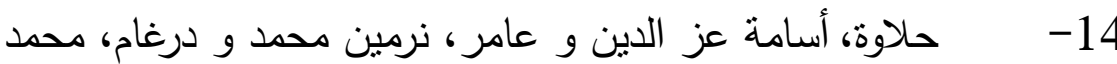
السعيد. (2018). النسيج والتطريز في التصميم وتأثيرهما على الأداء الوظيفي لأفمشة المفروشات. مجلة التصميم الدولية، كلية الفنون التطبيقية، جامعة حلوان، مجلد (8)، عدد (1)، يناير •

15 - ريحان، إيمان مصطفى إبراهيم. (2015). غرز التطريز كمدخل ابتكارى جديد فى وصل المشغولة المعدنية وزخرفتها. مجلة التصميم الدولية، كلية الفنون التطبيقية، جامعة حلوان، مجلد (5)، عدد (2)، أبريل. 16- زيدان، ميراهان فراج عرابى و عوام، أروى يحيى محمد. (2020). تطويع خصائص الخيوط المضيئة فى إثراء العباءة النسائية باستخدام تقنيات التطريز الآلى. مجلة الفنون والأدب وعلوم الإنسانيات والاجتماع، كلية الإمارات للعلوم التربوية، عدد (55)، أغسطس. سلامة، هبة عبد الله بسيونى. (2019). القيم الجمالية لزخارف الفنون

الإسلامية الإيرانية والإفادة منها فى تصميم وتطريز طرحة الزفاف. مجلة 
العمارة والفنون والعلوم الإنسانية، الجمعية العربية للحضارة والفنون الإسلامية،

عدد (13).

18- سليمان، هالة سليمان السيد. (2017). أثز اختلاف كثافات بعض غرز التطريز الآلى على مظهرية منتجات "الفولى فاشون". مجلة التصميم الدولية، كلية الفنون التطبيقية، جامعة حلوان، مجلد (7)، عدد (3)، أبريل. سويلم، أسماء سامى عبد العاطى و عطية، شيماء محمد محمد.

(2018). تأثثر بعض تقنيات التطريز الآلى على خواص الأقمشة الخفيفة.

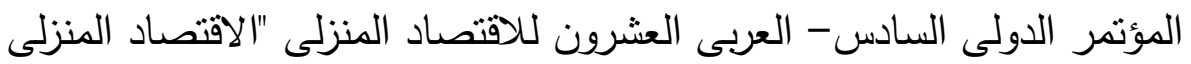
وجودة التعليم"، كلية الاقتصاد المنزلى، جامعة المنوفية.

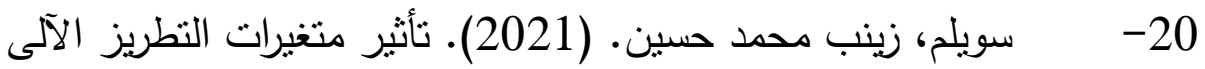
على مظهرية الأقمشة العازلة للماء. مجلة التصميم الدولية، كلية الفنون التطبيقية، جامعة حلوان، مجلد (11)، عدد (2)، مارس. عابدين، علية. (1996). دراسات فى سيكولوجية الملابس. الطبعة الأولى، دار الفكر العربى، القاهرة.

عبد الفتاح، لمياء إبراهيم أحمد و هاشم، ميمنة محمد الأباصيري.

(2018). المعايير التقنية للتطريز الآلي على أقمشة ستائر التل. المؤتمر العلمي الدولي الخامس، كلية التربية النوعية، جامعة طنطا. عمر، أحمد مختار عبد الحميد. (2008). معجم اللغة العربية المعاصرة. عالم الكتب، القاهرة. 24 - عيد، رشدي علي و شاهين، منى عبد الهادي و محمد، رماس عبد الحميد. (2014). تأثثر بعض عوامل التطريز الآلي على الخواص الطبيعية والميكانيكية للأقمشة لرفع جودة المنتج الملبسي. مجلة بحوث النربية النوعية، جامعة المنصورة، عدد (36)، أكتوبر • غازى، رانيا شوقى محمد و الزهرانى، خيره عوض عوضه. (2019). $-25$

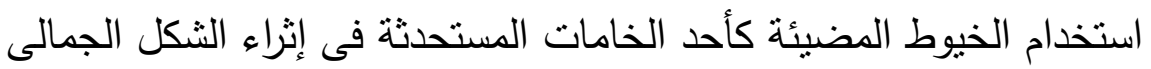


فى تصميم مكملات الملابس باستخدام تقنيات التطريز الآلى. مجلة الفنون والعلوم التطبيقية، كلية الفنون النطبيقية، جامعة دمياط، مجلد (6)، عدد (3)، بوليو - م بو

26- لطفى، سامية. (1997). موسوعة الملابس. منشأة المعارف،

$$
\text { الإسكندرية. }
$$

27- ماضى، نجلاء محمد أحمد. (2020). فاعلية برنامج تدريبى لتتمية

مهارات التطريز الآلى لتأهيل الخريجات لإقامة مشروعات صغيرة ومنوسطة.

مجلة بحوث التربية النوعية، جامعة المنصورة، عدد (57)، يناير •

28 - محمد، سعاد ماهر • (1977). النسيج الإسلامى. دار الثعب، القاهرة.

29- محمد، صافيناز محمد النبوى. (2021). النياشين العسكرية كوحدات

زخرفية تترى ملابس الأولاد فى مرحلة الطفولة المتأخرة وإمكانبة تتفيذها

بإسلوب التطريز الآلى. مجلة البحوث فى مجالات التربية النوعية، كلية التربية

$$
\text { النوعية، جامعة المنيا، مجلد (7)، عدد (34)، مايو. }
$$

30- Radostina A. Angel ova, Daniela Sofronova,

Veselina Nikolova. (2016). A case Study on the Defects in

Industrial Manufacturing of Embroidered Textile. Journal of Multidisciplinary Engineering Science and Technology (JMEST), Vol. (3), Issue (12).

31- Snook, Barbara. (1972). The Creative Art of

Embroidery. The Senefelder Printing co.1td, Purmerend, England.

32- www.dictionary. Cambridge.org appearance

33- https://kitabbat.com/ الأقمشة وأنواعها

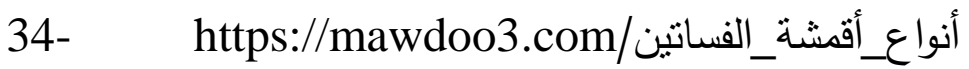

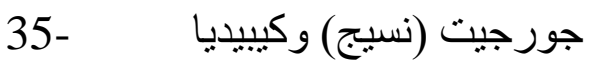

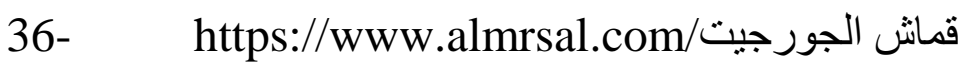

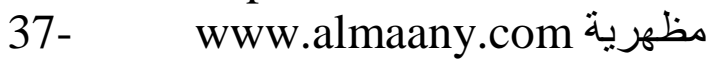

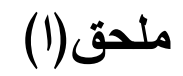

مواصفات العينات المطرزة 


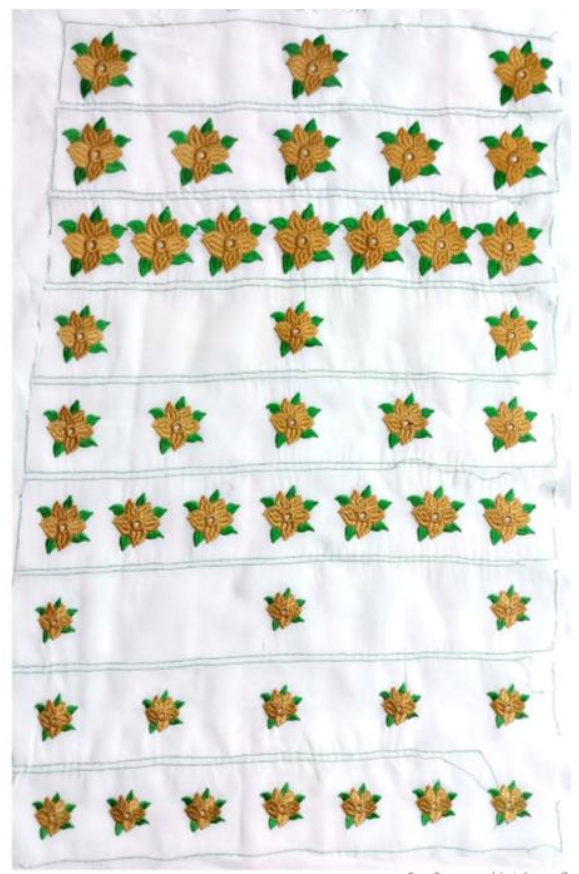

Satin stitch

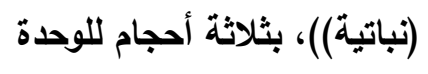

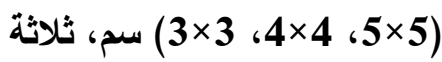

أعداد للوحدة الزخرفية (3، 5، 5، 7 (3)

وحدات فى المساحة المطرزة (5×35) سم.

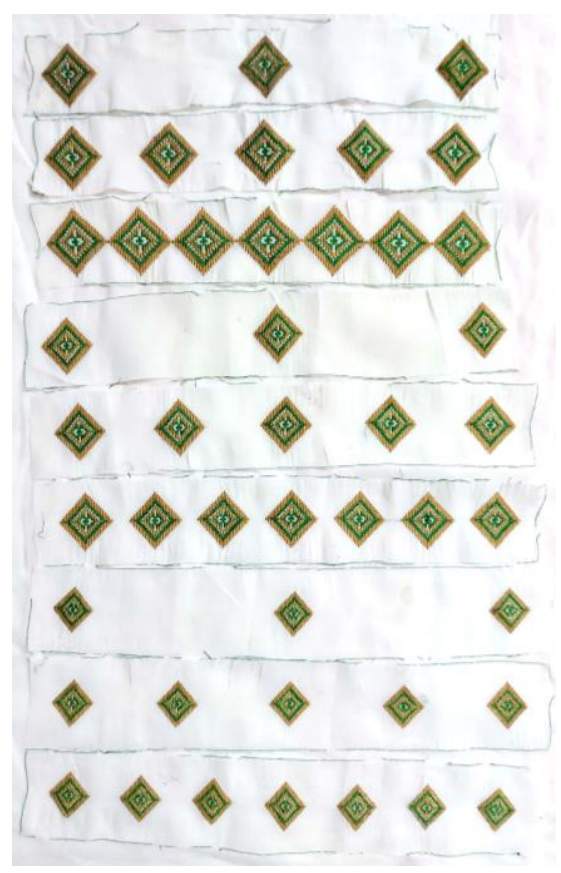

Satin stitch

( (كندسية)، بثلاثة أحجام للوحدة

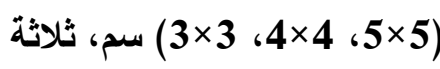

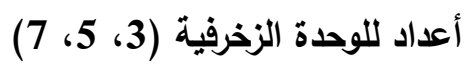

وحدات فى المساحة المطرزة (5×35) سم. 


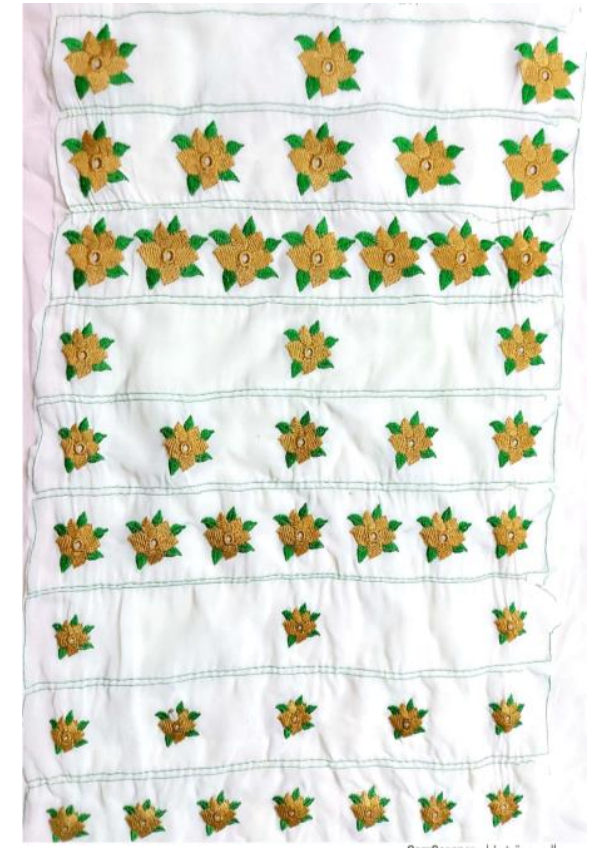

Tatami stitch

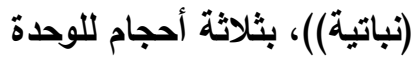

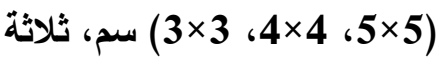
أعداد للوحدة الزخرفية (3، 5، 5، 7 (3) وحدات فى المساحة المطرزة (5 ×35) سم.

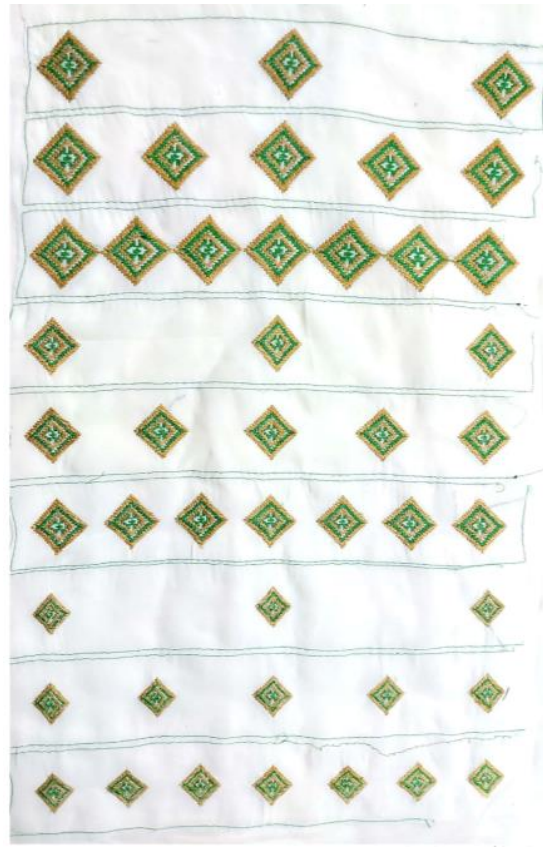

Tatami stitch

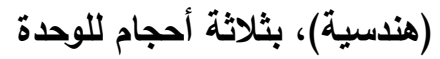

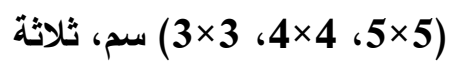
أعداد للوحدة الزخرفية (3، 5، 5، وحدات فى المساحة المطرزة (5×35) سمرة (5)، 


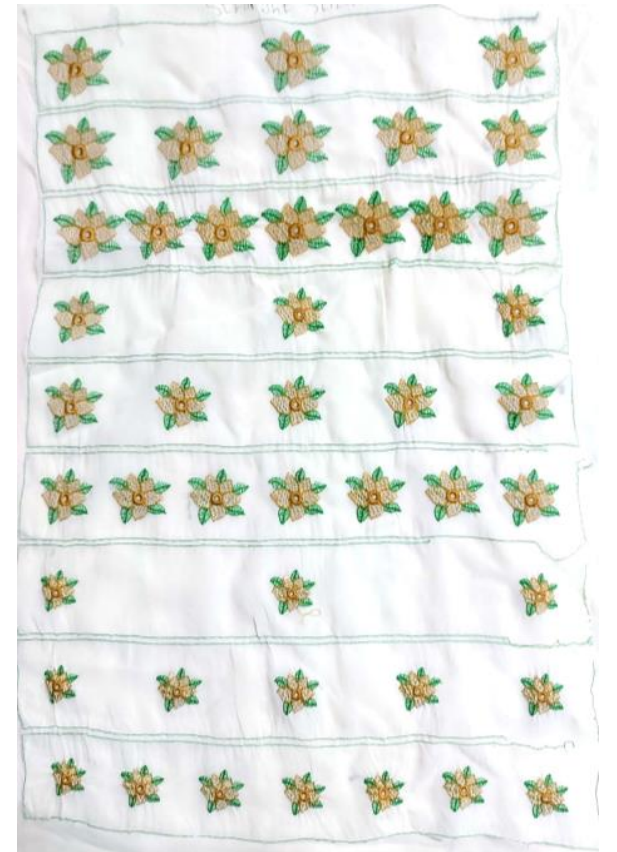

Straight stitch

$$
\text { (نباتية)، بثلاثة أحجام للوحدة }
$$

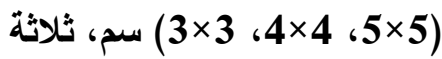

أعداد للوحدة الزخرفية (3، 5، 5، 7 (3)

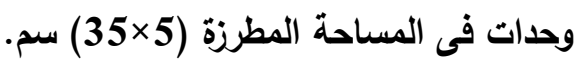

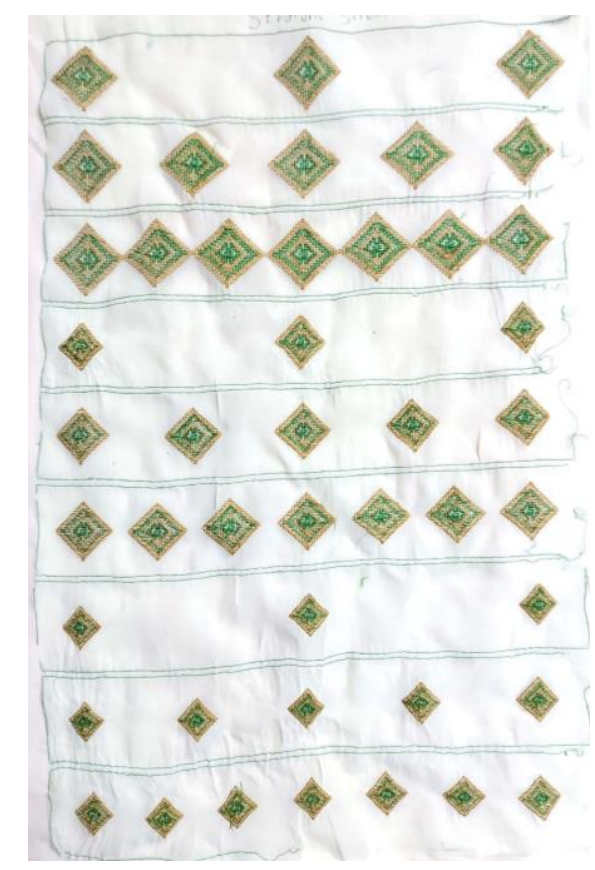

Straight stitch (هندية)، بثلاثة أحجام للوحدة

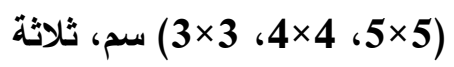

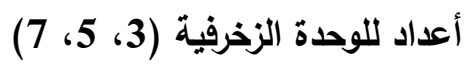

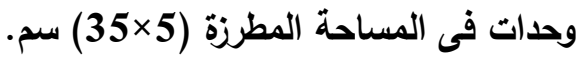

\section{ملحق (2)}

استمارة تقييم العينات المطرزة موجه إلى المتخصصين 


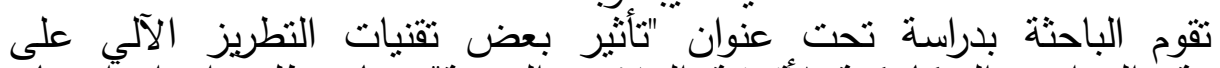

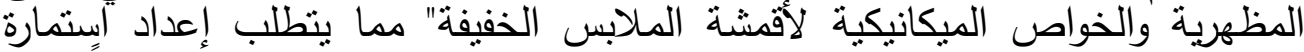

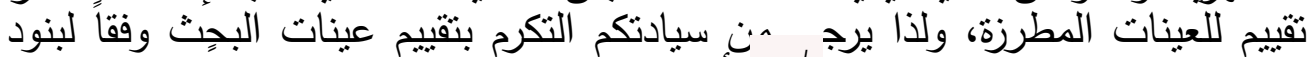

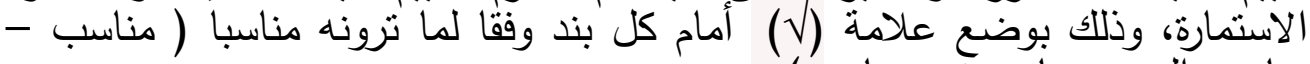
وتفضلوا بقبول وافر الإحترام

الباحثة

استمارة تقييم مظهرية العينات المطرزة

\begin{tabular}{|c|c|c|c|c|}
\hline \multicolumn{3}{|c|}{ 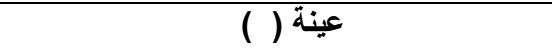 } & \multirow{2}{*}{ محاور التقييم } & \multirow[t]{2}{*}{ s } \\
\hline غير مناسب & مناسب إلى حذ ما & مناسب & & \\
\hline \multicolumn{5}{|c|}{ الدحور الأول: نوع غرزة التطريز الآلى } \\
\hline & & & أوكثكثة غرل الوحدة التطريز مع الخامة المستخدمة بحيث لا تسبب تجعد & 1 \\
\hline & & & تظهر الغرزة بوضوح فى الوحدة المطرزة. & 2 \\
\hline & & & يوجد دقة فى تطريز القطعة باستخدام هذا النوع من الغرز. & 3 \\
\hline & & & تعطى غرزة التطريز جمالا للوحدة المطرزة. & 4 \\
\hline \multicolumn{5}{|c|}{ المحور الثاني: حجم الوحدة الزخرفية } \\
\hline & & & الخارجبة الخفيفة. الوحدة الزخرفية مع طبيعة أقمشة ملابس السيدات & 1 \\
\hline & & & استخدام هذا الحجم للوحدة لا يؤدى لتهتاك أو تخريم زائد فى الخامة. & 2 \\
\hline & & & يظهر جمال التطريز باستخدام هذا الحجم للوحدة الزخرفية. & 3 \\
\hline \multicolumn{5}{|c|}{ المحور الثالث: عدد الوحدات الزخرفية } \\
\hline & & & يؤدى عدد الوحدات الدستخدم إلى الحفاظ على الخامة و عدم إجهادها. & 1 \\
\hline & & & يعطى عدد الوحدات المستخذم مظهرية عالية وجمالاً للقطعة المطرزة. & 2 \\
\hline & & & يفضل هذا العدد من الوحدات لتغطية المساحة المطرزة. & 3 \\
\hline \multicolumn{5}{|c|}{ المحور الرابع: نوع الوحدة الزخرفية المستخدمة في التطريز } \\
\hline & & & تتتلاءم الوحدة الزخرفية مع خامة الجورجيت الخففية. & 1 \\
\hline & & & والسيدات هن النوع (20-35). & 2 \\
\hline & & & تحقق القطعة الهطرزة مظهرية عالية باستخدام هذا النوع من الوحدات. & 3 \\
\hline
\end{tabular}

\section{ملحق (3)}




\begin{tabular}{|c|c|c|}
\hline الوظيفة & الإسم & r \\
\hline أستاذ الملابس و النسيج ـ كلبة التربية النو عبة - جامعة طنطا & أ.د/ رانيا محمد أحمد حمودة & 1 \\
\hline أستاذ الملابس و النسيج ـ كلية التربية النوعية - جامعة & أ.د// رحاب محمد على إسماعيل & 2 \\
\hline أستاذ الملابس و النسيج - كلية الاقتصاد المنزلى - جامعة & أ.د/ علا يوسف عبد اللاه & 3 \\
\hline أستاذ الملابس و المنسوجات - كلية التربية النو عية - جامعة & أ.د/ منا موسى غالب & 4 \\
\hline أستاذ الملابس و المنسوجات ـ كلية التربية النو عية - جامعة & أ.د/ نجدة إبر اهيم ماضي & 5 \\
\hline أستاذ تصميم الأزياء - كلية الاقتصاد المنزلي - جامعة & أ.د/ هدى محمد سامي غازي & 6 \\
\hline أستاذ الملابس و النسبج ـ كلية التربية النوعية - جامعة طنطا & أ.د// هيام دمر داش حسين الغز الى & 7 \\
\hline أستاذ الملابس و المنسوجات المساعد ـ كلية التربية النوعبة - & أ. م.د/ شيماء محمد محمد عطية & 8 \\
\hline مدرس الملابس و المنسوجاتـ كلية التربية النوعية - جامعة & د/ هاجر على عبد الفتاح النادى & 9 \\
\hline مدرس الملابس و المنسوجاتـ كلية التربية النو عية - جامعة & د/ هبة محمد محمد حمادة & 10 \\
\hline
\end{tabular}

\section{ملحق (4)}

استمارة تقييم العينات المطرزة الموجة إلى المستهلكات 
عزيزي المستهلك:

\section{تحية طيبة وبعد،}

تقوم الباحثة بدراسـة تحت عنوان "تأثثر بعض تقنيات التطريز الآلى على المظهريـة والخواص الميكانيكية لأقشـة الملابس الخفيفة" ، مما يتطلب إعداد استمارة استطلاع آراء المستهلكين، ولذا يرجى التكرم من سيادتكم بقراءتها وإبداء الرأي فيها وذلك بوضع علامــة (ل) في الخانـة الدالـة على رأي سيادتكم ( مناسب - مناسب إلى حد ماغير مناسـب)، مـع العلم بـأن هذه المعلومـات سـيتم اسـتخدامها في أغـراض البحثث العلمي.

$$
\text { وتفضلوا بقبول وافر الاحترام والتقدير }
$$

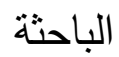

استمارة تقييم العينات المطرزة

\begin{tabular}{|c|c|c|c|c|}
\hline \multicolumn{3}{|c|}{ عينة ( ) } & \multirow{2}{*}{ بنود التقييم } & \multirow[t]{2}{*}{ s } \\
\hline 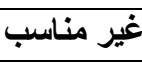 & مناسب إلى حـ ما & 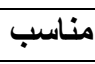 & & \\
\hline & & & تظهر الغرزة بوضوح فى الوحدة المطرزة. & 1 \\
\hline & & & يوجد دقة فى تطريز القطعة باستخدام هذا النوع من الغرز. & 2 \\
\hline & & & تعطى غرزة التطريز جمالا للوحدة المطرزة. & 3 \\
\hline & & & يتناسب حجم الوحدة الزخرفية مع طبيعة أفقشة ملابس & 4 \\
\hline & & & يظهر جمال التطريز باستخدام هذا الحجم للوحدة الزخرفية. & 5 \\
\hline & & & يفضل هذا العدد من الوحدات لتغطية المساحة المطرزة. & 6 \\
\hline & & & تتلاءم الوحدة الزخرفية مع خامة الجورجيت الخفيفة. & 7 \\
\hline & & & لففضنات والسيدات النوع من عمر (20- 35 35). لتطريز الفساتين المسائية & 8 \\
\hline
\end{tabular}

